UNIVERSIDADE DE SÃO PAULO

INSTITUTO DE PSICOLOGIA

LIDIA RODRIGUES SCHWARZ

EnvelheSer - A Busca do Sentido da Vida na Terceira Idade. Uma Proposta de Psicoterapia Grupal Breve de Orientação Junguiana 
EnvelheSer - A Busca do Sentido da Vida na Terceira Idade. Uma Proposta de Psicoterapia Grupal Breve de Orientação Junguiana

Tese apresentada ao Instituto de Psicologia da Universidade de São Paulo, como parte dos requisitos para obtenção do título de Doutor em Psicologia.

Área de concentração: Psicologia Clínica Orientadora: Profa. Dra. Therezinha Moreira Leite 
AUTORIZO A REPRODUÇÃO E DIVULGAÇÃO TOTAL OU PARCIAL DESTE

TRABALHO, POR QUALQUER MEIO CONVENCIONAL OU ELETRÔNICO, PARA FINS DE ESTUDO E PESQUISA, DESDE QUE CITADA A FONTE.

Catalogação na publicação

Serviço de Biblioteca e Documentação

Instituto de Psicologia da Universidade de São Paulo

Schwarz, Lidia Rodrigues.

EnvelheSer - a busca do sentido da vida na terceira idade: uma proposta de psicoterapia grupal breve de orientação junguiana / Lídia Rodrigues Schwarz; orientadora Therezinha Moreira Leite. -- São Paulo, 2008.

$333 \mathrm{p}$.

Tese (Doutorado - Programa de Pós-Graduação em Psicologia. Área de Concentração: Psicologia Clínica) - Instituto de Psicologia da Universidade de São Paulo.

1. Envelhecimento 2. Psicoterapia de grupo 3. Psicoterapia breve 4. Psicologia junguiana 5. Teste de Rorschach I. Título.

\section{QP86}




\section{EnvelheSer - A Busca do Sentido da Vida na Terceira Idade. Uma Proposta de Psicoterapia Grupal Breve de Orientação Junguiana}

Tese apresentada ao Instituto de Psicologia da Universidade de São Paulo, como parte dos requisitos para obtenção do título de Doutor em Psicologia.

Área de Concentração Psicologia Clínica

BANCA EXAMINADORA

Prof. Dr.:

Assinatura

Instituição

Prof. Dr.:

Assinatura

Instituição

Prof. Dr.:

Assinatura.

Instituição

Prof. Dr.:

Assinatura

Instituição

Prof. Dr.:

Assinatura.

Instituição 
Aos meus queridos "velhos": Meus pais Meus avós (in memoriam) Meus pacientes idosos Que me ensinaram e me ensinam que a força do caráter é fundamental e que o envelhecer tem sentido 


\section{AGRADECIMENTOS}

A Deus pelo dom da vida;

À minha orientadora, Profa. Therezinha Moreira Leite, que me acolheu como orientanda, confiou em mim, e, de forma paciente e generosa me mostrou um caminho para que eu pudesse desenvolver este projeto;

À Profa. Laura Villares de Freitas e ao Prof. José Tolentino Rosa, cujas sugestões no exame de qualificação possibilitaram uma ampliação de alguns tópicos e a focalização de outros pontos, o que foi fundamental para o aprimoramento deste trabalho;

À Profa. Salete Marisa Biagioni que, frente às minhas aflições para desenvolver a parte prática deste trabalho, indicou textos valiosos e se disponibilizou para discutir as sessões de forma estimulante e profunda. Pela amizade e pelo carinho;

À Ana Clara Gavião, pelas preciosas sugestões em relação à análise do Método de Rorschach;

À Profa. Leila S. Cury Tardivo, que me acolheu na Universidade de São Paulo, me estimulou e tem me acompanhado nas pesquisas e no atendimento aos idosos, dentro do APOIAR;

À Telma Rodrigues e Melissa Vieira Teixeira, cuja dedicação possibilitou que a análise quantitativa dos protocolos do Método de Rorschach transcorresse de forma cuidadosa e profunda;

Aos pacientes idosos que participaram da pesquisa e que me deram o privilégio de partilhar de suas vidas;

Ao coordenador da Universidade Livre da Terceira Idade da Universidade Metodista de São Paulo, Prof. Ms. Moses Benadiba, que possibilitou que a pesquisa se desenvolvesse junto aos seus alunos e que eu utilizasse os recintos da universidade para a realização dos atendimentos; 
À Universidade Metodista de São Paulo que permitiu que a parte prática da pesquisa se desenvolvesse dentro do Campus Vergueiro;

Às secretárias da Universidade Livre da Terceira Idade da Universidade Metodista de São Paulo, Sirlene Silva Parraga e Regina V. Luz, que, sempre de forma solícita e dedicada, colaboraram para que meu trabalho se realizasse de forma tranqüila e organizada;

Aos funcionários do Instituto de Psicologia da Universidade de São Paulo, em especial à Arlete Aparecida de Almeida, que sempre que solicitada me atendeu de forma atenciosa e prestativa;

Aos amigos, que direta ou indiretamente, estiveram sempre ao meu lado, ora silenciosos aguardando que eu tivesse um "tempinho para batermos um papo", respeitando o meu isolamento, ora lendo meus textos, dando sugestões, enviando livros e artigos que pudessem, de alguma forma me ajudar. O meu carinho especialmente para Cristiane Silvestre, Serafina Tolloni, Luís AntonioTolloni, Denise Mathias, Regina Gaiarsa, Patrícia Almeida e Meire Tofanello;

Aos parceiros do Apoiar, especialmente os que também atendem idosos, pelo incentivo e pela partilha de experiências;

Aos meus pacientes e alunos, que de diferentes formas, enriquecem a minha vida e me estimulam a crescer sempre;

Ao prof. Carlos Straccia, pela revisão cuidadosa e à Amanda Ferreira, pelo trabalho rápido e preciso de formatação;

À minha sobrinha Alessandra, que entre fraldas e papinhas, achou um tempo para traduzir o resumo para o inglês;

Ao Prof. José Tolentino Rosa que gentilmente traduziu o resumo para o francês;

Ao Marco Natali pela generosidade e amizade; 
À Yara Coelho (in memoriam) e ao Padre Amaral (in memoriam) que foram fundamentais para que eu encontrasse "o caminho" e foram embora sem conhecer as conclusões deste trabalho;

À Norma, que há muito tempo acompanha meu trajeto e me incentiva a buscar sempre novos desafios;

À Selma Coppini Pereira, amiga generosa e dedicada cuja colaboração durante as sessões permitiu que, a partir dos seus registros detalhados e organizados, eu pudesse realizar as análises de forma cuidadosa. A minha gratidão e amizade;

À Ivanise Teixeira de Almeida, minha "irmã de coração", que esteve sempre presente, ora ajudando nas traduções, ora lendo e relendo pacientemente meus textos e ajudando a depurar minhas idéias, ora apenas ouvindo minhas lamentações e suportando o meu cansaço. O meu carinho e a minha amizade;

Aos meus pais, que sempre me estimularam a ir atrás dos meus sonhos e a concretizá-los;

Aos meus familiares, irmãos, cunhadas, sobrinhos, primos, que, de diferentes formas, estiveram ao meu lado incentivando e carinhosamente torcendo por mim;

À minha futura nora Cíntia, pelo apoio e estímulo;

À minha nora Josi pela solicitude, carinho e colaboração nas pesquisas e nos fichamentos;

Aos meus filhos, Fernando, Eduardo e Thais, meus bens mais preciosos, que ajudaram tanto por meio de ações concretas, traduzindo, digitando, organizando os textos, como por meio do seu amor, com paciência nas horas em que eu estava estressada, com carinho e delicadeza em todas as horas. O meu amor profundo... 


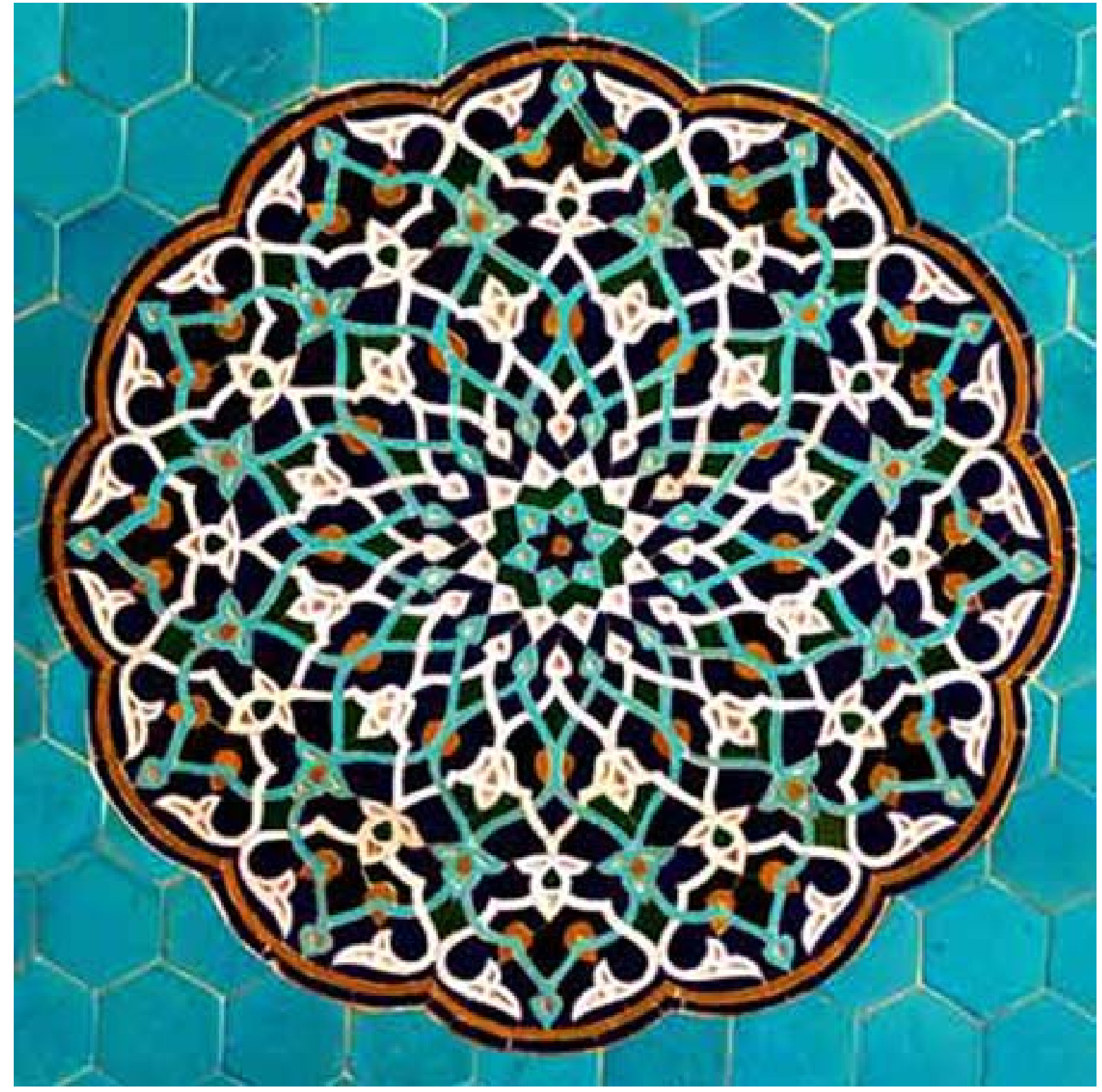

Nossa personalidade se desenvolve no curso da nossa vida a partir dos germes difíceis ou impossíveis de discernir, e só revelamos quem somos através de nossos atos. Somos como o sol, que nutre a vida da terra e produz todos os tipos de coisas estranhas, maravilhosas e maléficas... No início não sabemos que ações ou iniqüidades, que destino, qual o bem ou mal que temos dentro de nós, e somente o outono pode mostrar o que a primavera gerou. C. G. Jung 


\section{ENVELHESER}

Envelhecer

Ser alguém?

Ainda dá tempo para se conhecer?

Ainda dá tempo para viver?

Ser outro?

Ser mais pleno?

Ser mais autêntico?

O que resta para ser?

Ser resto?

Ser sábio?

Ser mais verdadeiro?

Ser o que se é...

Envelheser

O que fui, já não sou?

Quem está sob minhas rugas?

Me desconheço no meu passo lento

mas me reconheço quando olho para trás

e vejo o caminho feito

e as sementes brotando...

Envelheser

Colher o que foi plantado

Cultivar o que ainda cresce e pode desabrochar

Porque a vida flui eternamente

Amar sempre

Acreditar que todo caminho tem um significado

Acreditar que o envelhecer tem um sentido

E que o fim, assim como o começo, está profundamente conectado ao movimento circular da vida.

Primavera de 2006 


\section{O que aprendi com os meus queridos "velhos"}



Lembro dos meus avós paternos velhos, sempre velhos*. Eu era criança e eles, com provavelmente 45 ou 50 anos, já aparentavam ser velhos. Meus avós paternos, imigrantes espanhóis pobres, com semblante geralmente sério, eram pessoas simples e eram simplesmente avós: dedicados, cuidadosos, afetivos, cada um do seu jeito, respeitavam o ciclo da natureza e exerciam seu papel de avós assim como o pássaro canta porque sabe cantar...

Eram fortes, embora franzinos, ativos: ela ajudando nas atividades domésticas, principalmente na cozinha, e, segundo meu pai, "fazendo milagres com os poucos ingredientes que tinha para cozinhar para um bando de gente". Ele cuidava da horta e da bela parreira que havia no quintal da casa - uma casa muito simples, limpa, muito aconchegante e que tinha sido construída graças a mutirões de amigos imigrantes. Na época da colheita, meu avô exibia para todos, com orgulho, os belos cachos de uva colhidos. Era uma pequena parreira, mas os frutos eram distribuídos para todos os filhos, sobrinhos, vizinhos, compadres, e quem mais coubesse no coração deles.

As portas estavam sempre abertas para acolher os imigrantes compatriotas que chegavam todos os dias. Hoje, lembrando desse tempo, associo o que meus avós faziam com a Parábola dos Peixes e o milagre da multiplicação.

Eram tempos difíceis, mas eles, com todas as dificuldades, sabiam acolher, ser avós, envelheciam respeitando a própria natureza. Eles adoeceram, várias vezes "enganaram" o médico da família que os acompanhava, e partiram da mesma forma que viveram: com dignidade e paz.

Minha avó materna, minha "oma", era filha de alemães e não cheguei a conhecer. Meu nome é uma homenagem a ela. Ela morreu jovem, não chegou a 
envelhecer... Meu "opa" era austríaco, veio da Áustria procurando uma nova terra para viver, era aventureiro, mas amou este país e aqui criou suas raízes. Ele foi um dos primeiros professores de Santa Catarina, era culto, adorava operetas, pintura, estimulava o estudo e ficou viúvo muito cedo. Não se casou mais e precisou de muita ajuda para educar os sete filhos. Ele envelheceu pertinho de nós, gostava de ensinar alemão e, na falta de livros especializados, ele mesmo recortava ou desenhava figuras e escrevia em português e alemão para facilitar a nossa compreensão. Quando irritado, deixava escapar em alemão "aquelas palavras" que nenhum livro ensinava, e era dessa forma divertida que aprendíamos os palavrões mais interessantes. Ele era o centro dos nossos Natais, e seus olhos azuis clarinhos brilhavam quando todos cantavam as músicas natalinas em sua língua natal. Quando ele se foi, nossos Natais ficaram mais pobres e tristes...

Ele envelheceu como sempre vivera, nunca me pareceu ter conflitos com seus cabelos brancos ou com suas limitações. Um dia antes de

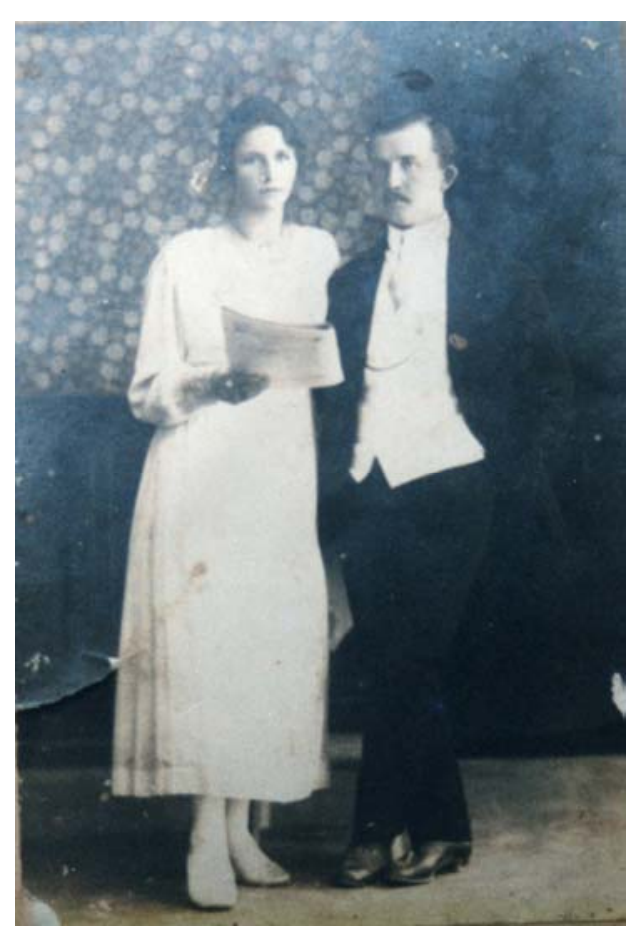
"partir", já doente, pediu para meu tio levá-lo até o sítio que adorava. Todos foram contra, mas meu tio o levou e no dia seguinte ele se foi. Hoje penso que ele foi embora em paz consigo mesmo e alimentado pela natureza de que gostava tanto.

Hoje, eu, na meia-idade, vivendo nessa sociedade complexa, em que tudo se dá no exterior, numa sociedade onde predominam o virtual, o descartável, a supervalorização da juventude e o preconceito contra o envelhecimento, acompanho idosos na clínica e nos cursos para terceira idade, cujo conflito maior é não querer envelhecer e sim rejuvenescer a qualquer custo.

O luto pela juventude perdida nessa população que envelhece não tem fim....

Meus pais são idosos, ele com 86 anos e minha mãe com 83. Ela cuida da casa, com todas as limitações que uma fratura na coluna impõe, mas não deixa de fazer seus dezessete bolos de frutas de Natal, todos os anos, para presentear todos 
a quem ama. Meu pai, quase cego em função de um glaucoma, lê um livro por mês sobre a História do Brasil, especialmente a de São Paulo. É um autodidata, continua a ler, mesmo com dificuldade, mas enxerga mais do que seus olhos possibilitam!

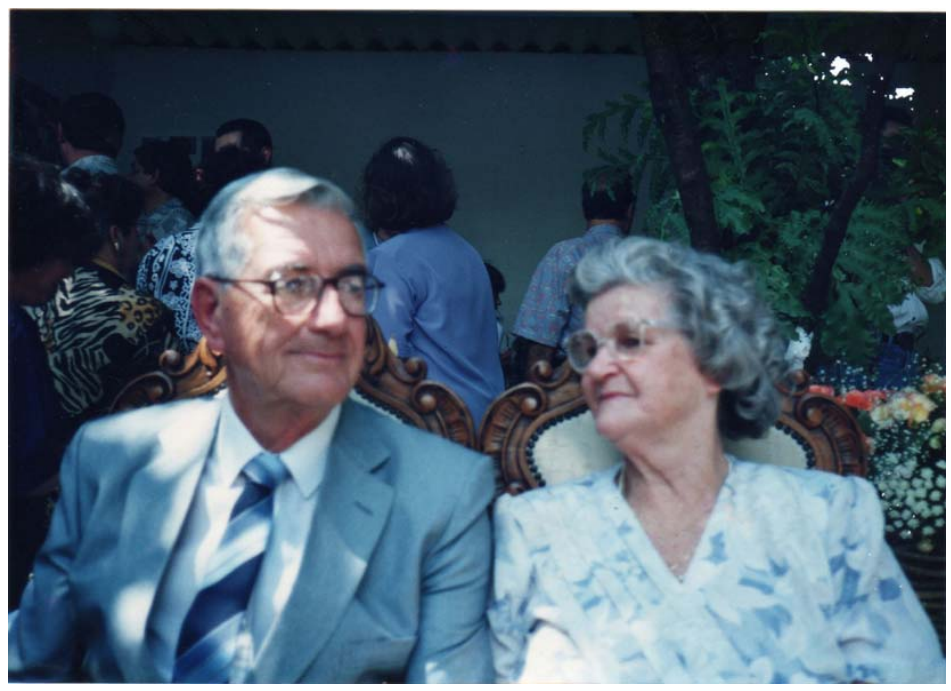

Sua casa, com suas árvores frutíferas e com a mesa sempre posta para alimentar, no sentido mais amoroso, os filhos, netos, bisnetos, sobrinhos e todos aqueles que sempre dão "um pulinho" para vê-los, também sempre está aberta.

Meus pais envelhecem, são bisavós e eu os vejo lutando com os limites (frustrados porque queriam fazer mais, ler mais, cozinhar e cuidar mais das plantas), mas não os percebo negando seu envelhecimento. Conversam, discutem por terem pontos de vista diferentes, vão ao quintal, minha mãe para ver as novas orquídeas que desabrocharam e meu pai para dar mamão para a grande família de sabiás que o visita todos os dias. Podem ser eles mesmos e, sendo eles próprios, podem acompanhar a passagem do tempo com dignidade.

Eles e meus avós me ensinaram e me ensinam todos os dias a importância da força do caráter e que o envelhecer tem um sentido...

\footnotetext{
* Concordo com Hillmann (2001) "Por isso que 'velho' é o termo apropriado para as pessoas durante os últimos anos de vida. Elas são chamadas de 'velhas'não simplesmente por causa do seu envelhecimento, mas por causa do seu valor como imagens da velhice" (p. 78). [grifos do autor]
} 


\section{RESUMO}

Schwarz, L. R. EnvelheSer - A busca do sentido da vida na terceira idade. Uma proposta de Psicoterapia Grupal Breve de orientação junguiana. 2008, 333 pp. Tese de Doutorado - Instituto de Psicologia, Universidade de São Paulo, São Paulo, 2008.

Atualmente já podemos nos considerar um país de meia-idade. O Brasil até 2025 será o sexto país do mundo com maior população idosa, e a maioria dos estudos aponta a importância da estimulação de um envelhecimento autônomo e com independência. As pesquisas sobre psicoterapia grupal e de tempo limitado, a partir do enfoque da Psicologia Analítica, são restritas e a nossa realidade sociocultural exige que delineemos novas modalidades de atendimento que sejam eficazes e, ao mesmo tempo, acessíveis para nossa população, especialmente a idosa. Esta tese visa propor uma nova modalidade de aplicação da Psicologia Analítica - a Psicoterapia Breve em Grupo com idosos - e verificar os seus benefícios. Participou da pesquisa um grupo de sete idosos, com idade variando entre 60 e 70 anos, sendo um homem e seis mulheres, alunos de uma Universidade Livre da Terceira Idade da região do $\mathrm{ABC}$. Foram realizadas entrevistas diagnósticas semiestruturadas individuais, e o Método de Rorschach foi aplicado na forma de testereteste, antes do processo terapêutico e após este, visando avaliar tanto a evolução de cada participante idoso como a do grupo. O processo terapêutico consistiu em dez sessões, e mais uma de follow up após três meses do término. O foco delimitado foi a auto-estima e alguns recursos foram utilizados durante as sessões, tais como, recursos expressivos (desenhos), material onírico e relaxamento. As imagens que emergiram foram abordadas de forma imagética, não-interpretativa. $A$ análise dos resultados do Rorschach do sujeito coletivo apontou para a existência de benefícios significativos do processo psicoterápico grupal breve, tais como: maior controle da ansiedade, redução do nível de crítica e do nível de ansiedade e de medo associados às relações interpessoais, o não reaparecimento de conteúdos relacionados à impulsividade e ao descontrole, controle emocional mais eficaz sem prejuízo das manifestações emocionais mais espontâneas, uma afetividade mais viva, com maior abertura para o contato com o outro. Alguns indicadores, que 
envolvem mudanças estruturais profundas, não sofreram alteração após a intervenção, o que sugere que só um processo analítico poderia atingi-los. Foi possível observar que a Psicoterapia Grupal Breve desenvolvida favoreceu o crescimento psicológico de cada participante idoso e do grupo, a estruturação do self relacional e do self grupal, a ampliação da consciência e ativou o desenvolvimento do processo de individuação.

Palavras-chave: Envelhecimento; Psicoterapia de Grupo; Psicoterapia Breve; Psicologia Junguiana; Teste de Rorschach 


\begin{abstract}
Schwarz, L. R. Growing Older. The search for the life meaning in the third-age. A proposal for Brief Group Psychotherapy of junguian psychology. 2008, 333 pgs. Doctoral Thesis - Instituto de Psicologia da Universidade de São Paulo, São Paulo, 2008.
\end{abstract}

Nowadays, we can already be considered a middle-age country. Until 2025, Brazil will be the $6^{\text {th }}$ country in world regarding elder population, and most studies point out the importance of stimulating an independent and autonomous aging. Researches about group psychotherapy within delimited time frame, from Analytical Psychology point of view, are restricted, and our socio-cultural reality demands that we outline new modalities of attendance that can be both efficient and accessible for our population, specially the elder. This thesis objective is to propose a new modality of Analytical Psychology application - Brief Group Psychotherapy with the elder - and verify its benefits. Took part in this research a group of seven elderly, ages from 60 to 70, one man and six women, students of Universidade Livre da Terceira Idade in $A B C$ - São Paulo. Individual semi-structured diagnostic interviews were made and Rorschach Method was applied as test-retest form, before and after the therapeutic process. The goal was to verify both each participant evolution as well as the whole group evolution. The therapeutic process was composed by ten sessions and an extra follow up session, three months after the process end. The delimited focus was self-esteem and some resources were used during the sessions, such as expressive resources (drawings), dreams material and relaxing. The images that emerged were approached in a non-interpretative imagetic way. The Rorschach analysis from group subject pointed out to the existence of significant benefits of the brief group psychotherapy process, such as: better anxiety control, reduction of criticism levels and the anxiety and fear levels related to interpersonal relationships, non-emergence of contents related to impulsivity and lack of control, a more effective emotional control with no damage of more spontaneous emotional manifestations, more vivid affectivity, with more opening for contact with others. Some indicators, which involves deep structural changes, did not suffer modifications after the intervention, what suggests that only an Analytical process could affect it. It was possible to observe that the Brief Group Psychotherapy developed helped the psychological growth of 
each elderly participant and the group, the framing of relational self and group self, the amplification of consciousness and activated the development of individuation process.

Key-words: Analytical Psychology; Rorschach Test; Group Psychotherapy; Brief Psychotherapy; Aging 


\section{RÉSUMÉE}

Schwarz, L. R. Le travail avec les âgées est considéré comme une recherche de la signification de la vie dans le troisième âge. Une proposition psychothérapie brève de groupe sous la psychologie analytique junguienne. 2008, 333 pgs. Thèse de Doctorat - I'Institut de Psychologie de l'Université de São Paulo, São Paulo, 2008.

De nos jours, nous pouvons déjà êtres considérés un pays de moyen âge. Jusqu'en 2025, le Brésil sera le $6^{\mathrm{e}}$ pays en monde concernant une population plus âgée, et la plupart des études précisent l'importance de stimuler un vieillissement indépendant et autonome. Les recherches sont restreintes, au sujet de la psychothérapie de groupe et de temps délimité, sous le point de vue de la psychologie analytique, et notre réalité socioculturelle demande que nous décrivions des nouvelles modalités de l'assistance qui peuvent êtres efficaces et accessibles à la population, particulièrement les âgés. L'objectif de cette thèse est de proposer une nouvelle modalité de l'application de la psychologie analytique - brève psychothérapie de groupe avec l'âgé - et de vérifier ses bénéfices. Un groupe de sept personnes âgées a participé de cette recherche, âges de 60 à 70, un hommes et à six femmes, étudiants d'une Course Libre destinée a la Troisième Âge, dans une université de la région métropolitaine de Sao Paulo. Différentes entrevues diagnostiques semis structurés ont été faites, et la méthode de Rorschach a été appliquée comme testretest forme, avant et après le processus thérapeutique. L'objectif était de vérifier les deux, chaque évolution de participant aussi bien que l'évolution de groupe entière. Le processus thérapeutique s'est composé par dix sessions et une session supplémentaire de suivi, trois mois après la finalisation de processus. Le focus délimité était l'amour-propre et quelques ressources ont été employées pendant les sessions, comme les ressources expressives (retraits), le matériel de rêves et la relaxation.Les images qui ont émergé ont été approchées d'une manière imagetique et non interprétative. L'analyse de Rorschach du sujet collective, du groupe, a précisé l'existence des focus significatif du bref processus de psychothérapie de groupe, comme : une meilleure contrôle de l'anxiété, une réduction de niveaux de critique et de l'anxiété, et de peur associé aux rapports interpersonnels, à la non apparition du contenu lié à l'impulsivité y au incontrôlabilité, du contrôle émotionnel 
plus efficace sans les dommages des manifestations émotives plus spontanées, une affectivité plus vive, avec plus d'ouverture pour le contact avec d'autres. Quelques indicateurs qui comportent les changements structurels profonds n'ont pas souffert des modifications après l'intervention, ce qui suggère que seulement un processus analytique de longue duration pourrait les affecter. II était possible d'observer que le bref processus de groupe développé a aidé l'évolution psychologique de chaque vieux participant et du groupe, la structuration du self relationnel e du self groupal, et l'amplification de la conscience a activé le développement du processus d'individuation.

Mots-clés: Psychologie analytique; Le Test de Rorschach; Psychothérapie de groupe; Psychothérapie Bref; Vieillissement; Agée. 


\section{LISTA DE TABELAS}

Tabela 1a - Aspectos Intelectuais........................................................... 132

Tabela 1b - Aspectos Afetivos............................................................... 132

Tabela 2a - Comparação entre os Resultados de Cada Participante e no Sujeito Coletivo com os Dados Normativops de Gavião (2002), na Situação Teste (antes da Psicoterapia Grupal Breve)................................................. 133

Tabela $2 b$ - Comparação entre os Resultados de Cada Participante e no Sujeito Coletivo com os Dados Normativops de Gavião (2002), na Situação Reteste (após da Psicoterapia Grupal Breve) 


\section{SUMÁRIO}

RESUMO

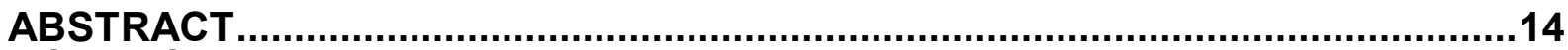

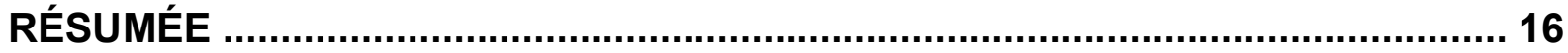

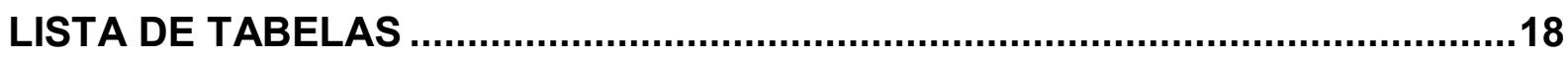

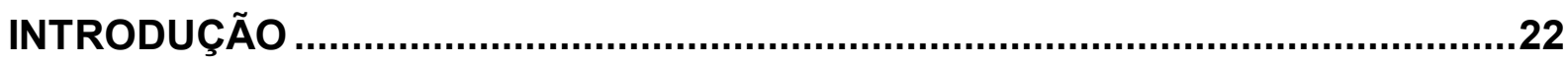

CAPÍTULO I...............................................................................................29

1. O TEMPO DO ENVELHECIMENTO .............................................................29

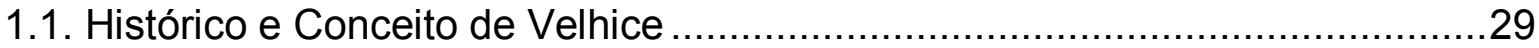

1.2. Um País de Cabelos Grisalhos ............................................................. 31

1.3. Envelhecendo e se Desenvolvendo..................................................... 34

1.4. A Vivência do Envelhecimento nos Homens e nas Mulheres .........................37

1.5. O Envelhecimento e os Papéis Sociais ................................................. 38

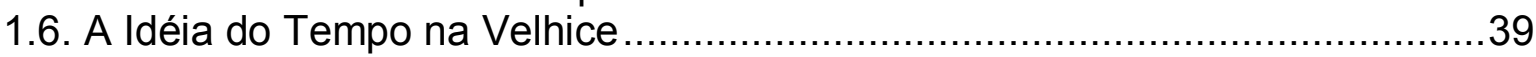

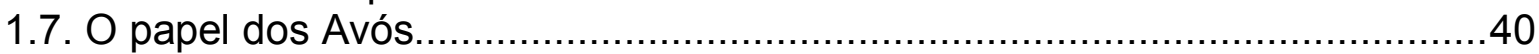

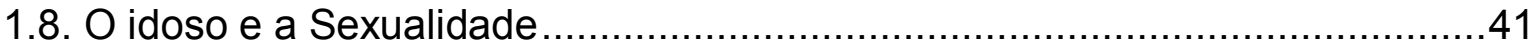

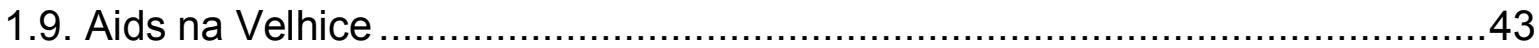

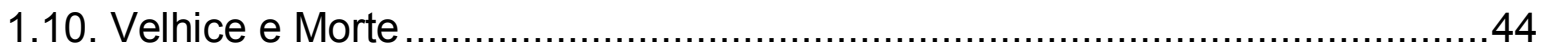

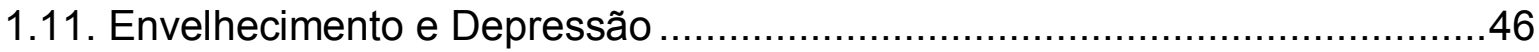

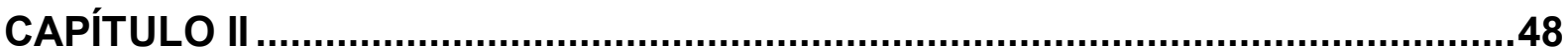

1. ALGUNS CONCEITOS DA PSICOLOGIA JUNGUIANA ................................48

1.1. A Visão de Homem e de Mundo .........................................................48

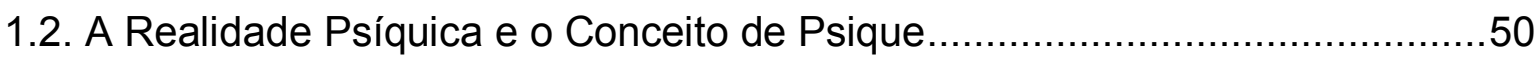

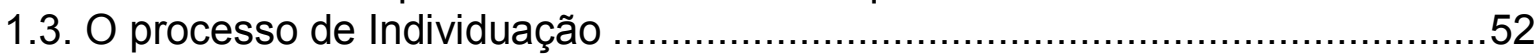

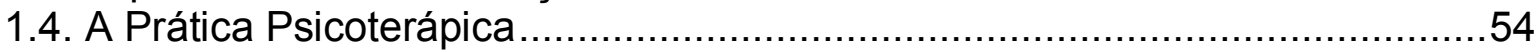

1.4.1. Princípios Básicos da Análise Junguiana .............................................. 54

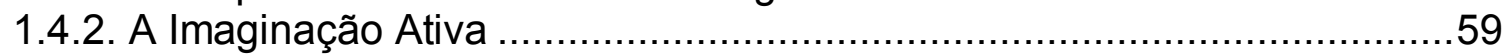

1.4.3. O Uso dos Recursos Expressivos na Psicoterapia ...............................62

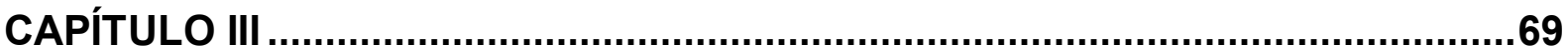

1. O PROCESSO DE ENVELHECIMENTO E O SENTIDO DA VIDA ......................69

1.1. A visão de Jung: O Envelhecimento como Tempo de Revisão de Vida .........69

1.1.1. O Desenvolvimento Humano e as Etapas da Vida.................................69

1.1.2. A Primeira Metade da Vida..................................................................... 72

1.1.3. A Metanóia - Tempo de Revisão de Vida ..........................................73

1.1.4. Fase de Transição entre a Meia-Idade e a Velhice ..................................75

1.1.5. A Velhice ........................................................................................ 77

1.1.6. A Morte e a Vida Pós-Morte ........................................................ 81

1.2. A visão de Hillman: o envelhecimento como momento de moldar a força do

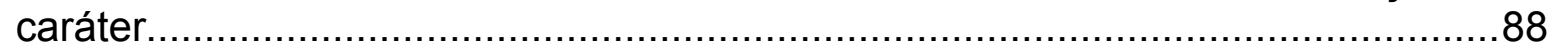

1.2.1. Um Breve Olhar sobre a Psicologia Arquetípica ................................ 88

1.2.2. O Envelhecimento e a Necessidade da Alma .................................. 89



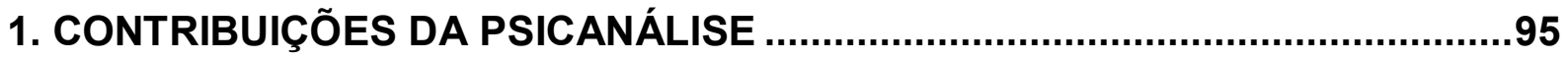

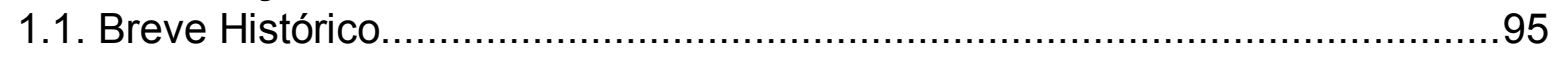




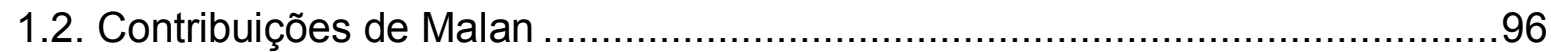

1.3. Contribuições de Ryad Simon ...........................................................100

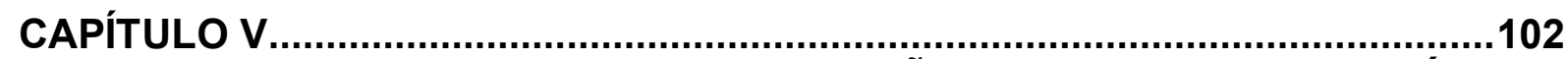
1. DIFERENTES MODALIDADES DE APLICAÇÃO DA PSICOLOGIA ANALÍTICA

1.1. Pressupostos Teóricos da Psicoterapia Grupal de Orientação Junguiana ...102

1.1.1. Alguns Princípios Gerais das Grupoterapias......................................102

1.1.2. Psicoterapia Grupal de Orientação Junguiana ...................................103

1.2. Fundamentos Teóricos para uma Psicoterapia Grupal Breve de Orientação

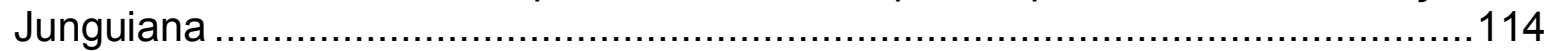

1.2.1. A crise como Possibilidade de Crescimento........................................114

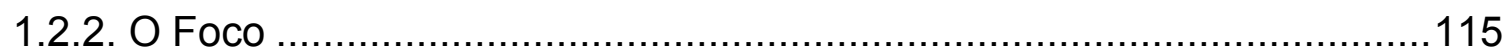

1.2.3. A Importância do Diagnóstico............................................................116

1.2.4. O Planejamento e a Técnica do Processo da Psicoterapia Breve .........119

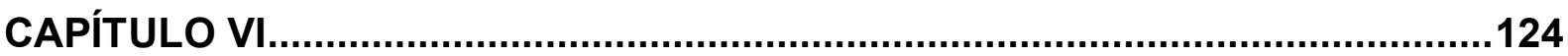

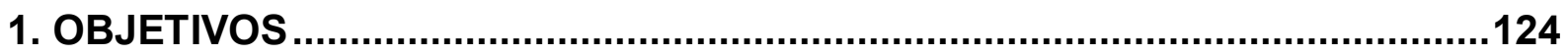

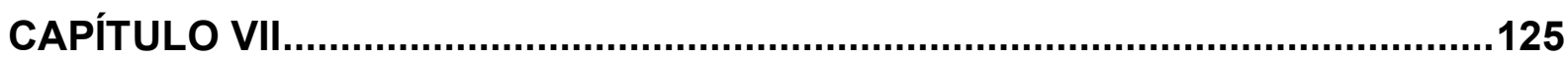

1. MÉTODO

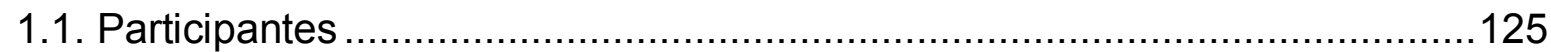

1.2. Procedimento: Fases e instrumentos...............................................125

1.2.1. $1^{\text {a }}$ Fase: Entrevista Individual Aberta ................................................126

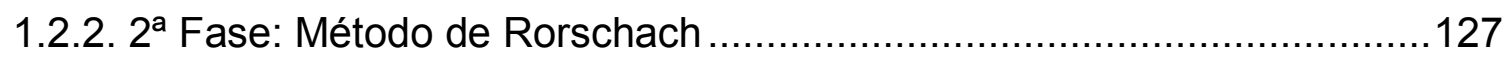

1.2.3. $3^{\mathrm{a}}$ Fase: A Psicoterapia Grupal Breve ...........................................127

1.2.4. $4^{\text {a }}$ Fase: Reaplicação do Método de Rorschach ................................128

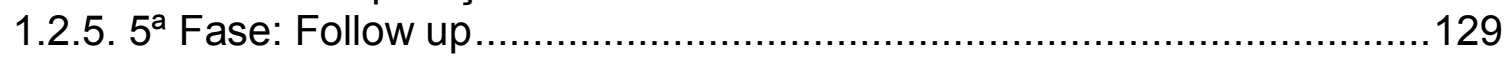

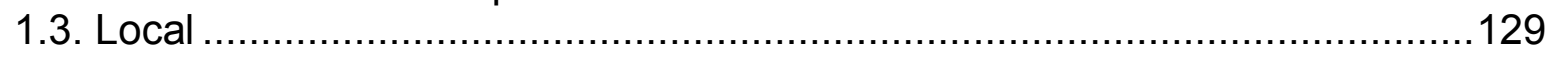

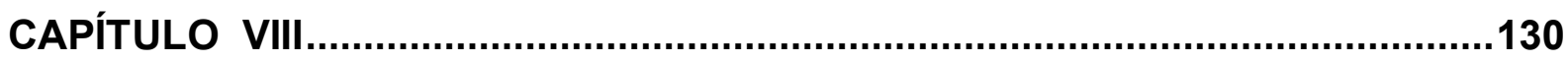

1. RESULTADOS

1.1. Análise Qualitativa das Entrevistas e Perfil do Sujeito Coletivo..................130

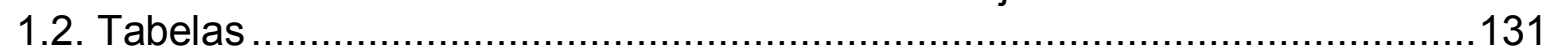

1.2.1. Relação dos Índices Utilizados, de Acordo com o Sistema de Klopfer

(Klopfer \& Kelly, 1946/1972), com a teoria desenvolvida por esse autor .........131

1.3. Análise Comparativa entre os Resultados da Aplicação do Rorschach e os do

Reteste, após o Processo de Psicoterapia Grupal Breve, de Cada Participante.134

1.3.1. Participante Cássia .................................................................... 135

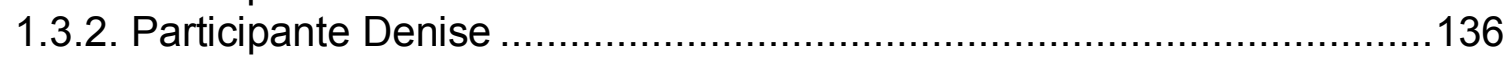

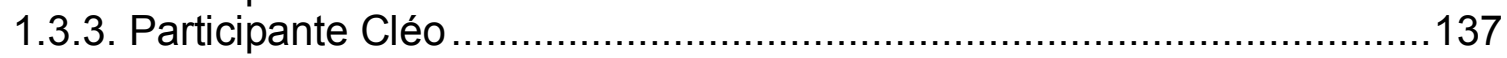

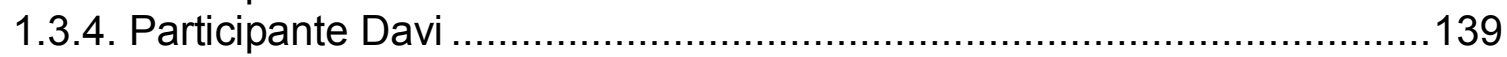

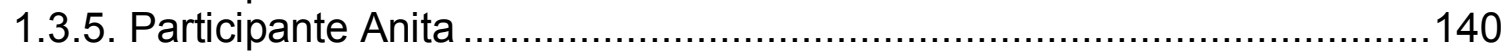



1.3.7. Participante Marta ...................................................................... 144

1.4. Análise Comparativa entre os Resultados do Sujeito Coletivo na Aplicação do

Rorschach e na Reaplicação, após a Psicoterapia Grupal Breve........................145

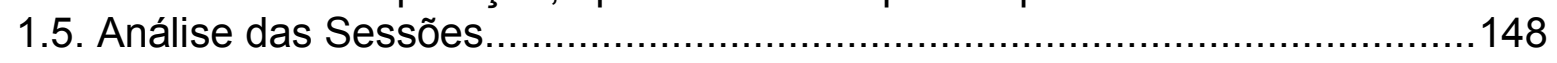

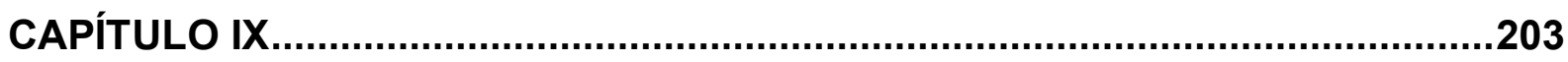




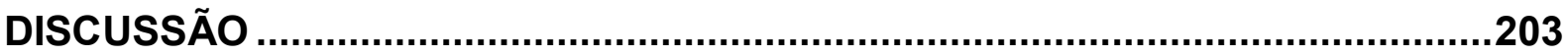

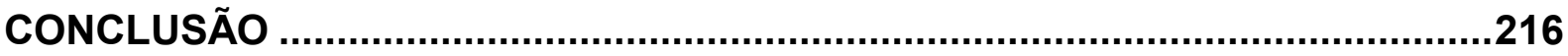

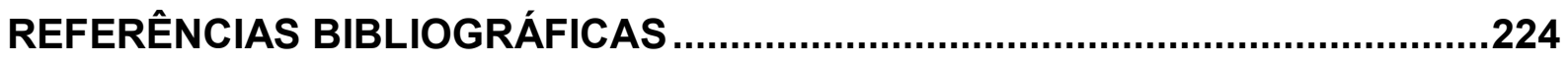

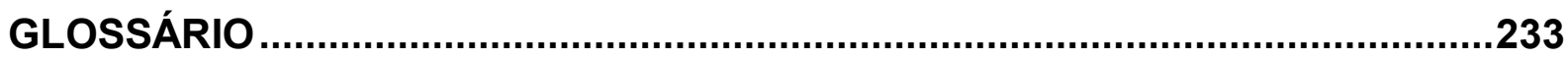

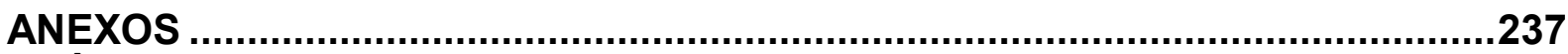

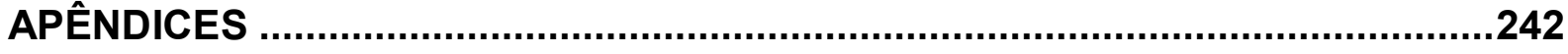




\section{INTRODUÇÃO}

1951...

A década de 1950 revelou-se um período de profundas mudanças num mundo pós-guerra, repleto de revoluções comportamentais e tecnológicas... a descoberta do DNA, a vacina para a Poliomelite, o lançamento do primeiro satélite artificial, o Sputnik I... No Brasil, o início da indústria automobilística, a inauguração do primeiro canal de televisão revolucionando a comunicação etc.

Minha infância...

Os Contos de Fadas, que eram lidos e relidos prazerosamente, alimentavam minha alma e minha imaginação e tornavam meu olhar mais vivo e minha vida mais rica.

$\mathrm{Na}$ adolescência, o prazer pelas artes: o desenho, a pintura, a música preenchiam a minha vida e, com certeza, me ajudavam a lidar com as crises dessa fase. Na época, não havia a profusão de cursos que temos hoje, eu simplesmente ia pintando, desenhando...

Era simples, natural, eu apenas sentia vontade de expressar o que sentia e o fazia. Sentia o equilíbrio que tais atividades propiciavam, seguia minha intuição tal como o animal que instintivamente procura a erva de que necessita para se curar.

O interesse pelos contos, fábulas, rabiscos, pinturas ficou tudo misturado dentro de mim e maravilhosamente emergiu durante minha graduação na PUCSP quando tive contato com uma psicologia que, além de focar o aprendizado conceitual, por meio das várias teorias psicológicas, privilegiava uma compreensão profunda e integrada da psique por meio de diferentes atividades vivenciais e de um trabalho imagético. Participava ativamente da vida universitária através de monitorias, e, sempre que possível, de grupos vivenciais dentro e fora da universidade que serviram para incrementar o meu interesse pelo trabalho psicoterápico com imagens, sob a luz da Psicologia Analítica.

Tinha sensação de que a minha história tinha me preparado para lidar, agora profissionalmente, com um mundo simbólico já conhecido. A cada aula com mestres admiráveis, generosos e ousados, inclusive frente às pressões do meio acadêmico da época, eu me sentia em casa. Eram muitos os mestres e a eles sou muito agradecida: prof. Pethö Sandor, Isabela Di Santis, Maria Cristina de Barros 
Carvalho, Dra. Aniela Ginsberg, Joel Goesling, Tessy, Elvira Mello Vagner, Silvia Portela, Di Loreto, Denise Ramos e muitos outros.

O trabalho interpretativo com as técnicas projetivas gráficas, com as associações a partir das manchas do Método de Rorschach, e com as imagens que emergiam após o relaxamento, me mobilizava, me estimulava a querer saber mais e apontava a existência de um caminho, para a compreensão do fenômeno psíquico, que a ciência positivista não tinha condições de oferecer.

A Psicologia Analítica entrou na minha vida através da minha análise pessoal no segundo ano da graduação, e de imediato eu soube que essa linha teórica contemplava uma visão de ser humano compatível com a minha.

Ainda na graduação eu estranhava a ênfase no estudo do desenvolvimento da criança e do adolescente, aliás, os estudos sobre a psicologia da adolescência estavam na moda. É como se o mais importante da vida terminasse na adolescência... Foi nas supervisões com a professora Elvira Wagner, mais tarde Coordenadora do Curso de Gerontologia do Instituto Sedes Sapientiae, que comecei a aprender sobre a psicologia da meia-idade e do envelhecimento. Nesse período, a maioria das pesquisas ainda era voltada para as mudanças físicas e para as patologias típicas do envelhecimento, e a profesora Elvira foi uma das pioneiras a pesquisar os processos saudáveis dessa fase e a analisá-los sob o enfoque junguiano.

Após o fim da graduação, iniciei meu trabalho como psicóloga clínica me dedicando ao psicodiagnóstico e à psicoterapia, e paralelamente iniciei minha vida docente ministrando, para o Curso de Psicologia do Instituto Metodista de Ensino Superior, hoje Universidade Metodista de São Paulo, disciplinas relacionadas às técnicas de exame psicológico.

Minha prática clínica sempre esteve focada no atendimento individual, mas mais tarde alguns trabalhos (Schwarz, 1998; Schwarz, 2000), com alunos da Universidade Livre da Terceira Idade da Universidade Metodista de São Paulo, apontaram para a possibilidade de um trabalho em grupo e com tempo limitado. A primeira experiência foi desenvolvida durante a disciplina "Oficina de Artes"ministrada para cerca de 60 alunos, com idade entre 45 e 75 anos, que constataram, no fim do curso, que mudanças importantes em suas vidas tinham ocorrido. Eu levava materiais diversos (argila, folhas, lápis de cor, sucata, giz de cera, tintas etc.) e solicitava ou que "brincassem" com os mesmos, ou sugeria um 
tema a partir do qual eles podiam se expressar. Essa primeira experiência me entusiasmou, e passei a desenvolver outros módulos semelhantes.

Em meados de 2000, propus para a mesma Universidade o início de um grupo terapêutico, não mais uma disciplina, para dez pessoas, durante dois meses e duração de uma hora por semana. Essas sessões ocorreram antes do período de aula, na própria sala da instituição. Esse trabalho (Schwarz, 2002) e outros (Schwarz, 2007) que desenvolvi tiveram resultados muito gratificantes e foram fundamentais para que eu pudesse avaliar os aspectos positivos e negativos desse tipo de intervenção.

Neste momento, além da docência, atuo como psicoterapeuta de orientação junguiana em consultório e faço parte do Projeto APOIAR, serviço abrigado no Laboratório de Psicologia Clínica Social do Instituto de Psicologia da USP, atuando no núcleo de atendimento a idosos, sob coordenação da Profa. Livre-Docente Leila S. Cury Tardivo. Nestes anos, o trabalho desenvolvido no APOIAR tem sido muito gratificante e estimulado muitas pesquisas (Schwarz, Altman, \& Tardivo, 2006; Schwarz, Altman \& Tardivo, 2007).

Todas essas experiências foram muito significativas e me estimularam a desenvolver esta tese de doutorado.

O grande desafio para o desenvolvimento deste trabalho que ora apresento foi buscar na literatura da Psicologia Analítica os conceitos que pudessem fundamentar uma modalidade diferente de aplicação da teoria de Jung, especificamente sobre a abordagem grupal breve, e aprofundar os meus conhecimentos sobre o processo de envelhecimento e a velhice.

A proposta de um novo tipo de prática clínica é sempre assustadora e geralmente incômoda por exigir mudanças e "sacudir" idéias já estabelecidas. A escola clássica, que até hoje se mantém fiel às idéias originais de Jung, questiona a prática grupal e também a breve, mas a nossa realidade sociocultural exige a criação de novos meios que possibilitem, de modo mais efetivo, que a Psicologia Analítica contemple questões contemporâneas importantes.

Penso, como Rodrigues (2006), que os problemas que afligem a sociedade atual, especificamente a brasileira, não podem ser resolvidos só a partir do tratamento psicoterápico individual, nos moldes existentes na Europa do século XIX.

O progresso e a evolução tecnológica do nosso século exigem que repensemos os modelos anteriores de aplicação da Psicologia Analítica e que 
possamos, com seriedade e estudo, delinear novas modalidades de atendimento que sejam eficazes e, ao mesmo tempo, acessíveis para nossa população, especialmente a idosa.

Essas novas modalidades não podem perder de vista o conceito de saúde mental e os objetivos de prevenção. A definição de Preston de saúde mental (citado por Knobel, 1986) como a capacidade que tem o ser humano de viver respeitando seus limites físicos, de se relacionar com seus pares, sentir-se feliz, produtivo e não ser um peso para os demais, parece-me muito pertinente para embasar o processo psicoterápico grupal breve de orientação junguiana que irei mais para frente desenvolver.

Concordo com Sant'Anna (2005), quando este assinala que os junguianos têm se preocupado excessivamente com o estilo ou o método junguiano e têm se distanciado de questões essenciais relacionadas a uma prática clínica mais próxima da nossa realidade sociocultural.

Rodrigues (2003) propõe que pensemos sobre os limites entre o plano individual e o coletivo na abordagem junguiana e que reconheçamos a pluralidade de enfoques que podem se dar a partir da obra de Jung.

No desenvolvimento deste trabalho, que visou verificar a eficácia da Psicoterapia Grupal Breve, de orientação junguiana, em idosos, encontrei muitas dificuldades tanto no que se refere à literatura, muito restrita, sobre Psicoterapia Breve realizada por junguianos, quanto sobre a Psicoterapia Grupal, mas, sem dúvida nenhuma a maior dificuldade e os mais intensos sentimentos de angústia, durante meus estudos e pesquisas sobre o significado da velhice, se referem ao confronto com o meu próprio envelhecimento. Mais uma vez meu self escolheu um caminho peculiar para eu lidar com esta fase da minha vida...

Esses meus sentimentos são confirmados pela fala de Barbieri (2003), quando esta autora diz que inevitavelmente toda pesquisa sobre a velhice leva o pesquisador a entrar em contato com o próprio processo de envelhecimento.

Espero que esta pesquisa possa contribuir para questões importantes da contemporaneidade tal como o atendimento grupal breve de idosos. Esta proposta de intervenção visa também garantir que, mesmo com um tempo limitado e com um foco numa determinada situação-problema, a qualidade do atendimento se mantenha a um custo acessível para uma população que, de modo geral, sobrevive às custas apenas da aposentadoria. 
O grupo e o indivíduo têm características diferenciadas, e, como diz Rodrigues (2003), devemos evitar generalizações que nos levem a refletir o grupo como se fosse um indivíduo. Sei que seria irresponsável apenas transpor alguns conceitos, entre eles um central que é a individuação, do campo individual para o grupal. É preciso pesquisa e estudo para que novas modalidades de aplicação da Psicologia Analítica sejam passíveis de utilização.

Zinkin (1998) observa que Jung via os grupos com características mais destrutivas do que criativas e preocupava-se com o perigo que isto poderia representar para o indivíduo, mas esse autor lembra que alguns trabalhos atuais, como os desenvolvidos pelo Instituto C. G. Jung de Nova York e relatados por Greene (citado por Oliveira, 2006), apontam os aspectos positivos da terapia grupal.

Zinkin (1998) reconhece que há algumas diferenças inevitáveis entre o processo individual e grupal, mas assinala que a individuação pode se processar não somente na análise individual, mas também no setting do grupo.

Assim como Rodrigues (2003), ao consultar os anais dos congressos latinoamericanos de psicologia junguiana, entre 2001 e 2003, constatei a preocupação dos junguianos com temas sociais, mas, a respeito de experiências terapêuticas com grupos, encontrei poucos informes, o que revela que continuamos restritos aos nossos consultórios e a um atendimento individual. Quanto à Psicoterapia Breve de orientação junguiana, considero importante destacar 0 trabalho pioneiro desenvolvido por Melo (1998) e Biagioni (2005).

Quando elaborei meu projeto de doutorado focando a Psicoterapia Grupal Breve, sob a luz da Psicologia Analítica, eu sabia das dificuldades que encontraria ao propor uma modalidade diferente de aplicação dos conceitos junguianos, fora do modelo clássico de atendimento. Essas dificuldades se tornaram também a mola propulsora para o desenvolvimento do meu trabalho que visa contribuir para que a psicologia junguiana amplie seu campo de atuação no nosso meio, levando em conta as necessidades da nossa sociedade atual, e, principalmente, da população idosa.

A seguir relaciono os capítulos e o teor de cada um deles. No capítulo 1 apresento algumas pesquisas importantes sobre a velhice e o envelhecimento: durante muitos anos, a maior parte das pesquisas enfocou a psicologia do desenvolvimento da infância e da adolescência, procurando esclarecer fases e mecanismos característicos dessas etapas. Hoje em dia, há maior interesse, tanto 
no Brasil como na maior parte dos países do mundo, pela pesquisa a respeito da psicologia do envelhecimento, o que tem acarretado transformações na própria visão do desenvolvimento do ser humano, desde o seu nascimento até a sua morte. $O$ Brasil enfrenta uma evolução demográfica, e desse movimento uma das conseqüências é o envelhecimento populacional. Atravessamos uma transição demográfica, gerada tanto pela redução das taxas de mortalidade como de natalidade, que exige novos estudos e pesquisas, e vivemos uma época em que o desenvolvimento tecnológico e da medicina possibilita maior qualidade de vida para as pessoas.

Especificamente, na sociedade brasileira, a parcela da população jovem vem caindo, e o Brasil, antes conhecido como "um país jovem", hoje se vê com fios brancos revelando seu envelhecimento. A forma, o jeito de cada pessoa envelhecer depende de vários fatores: condições sociais, culturais, econômicas, físicas e características de personalidade. Apresento nesse capítulo vários estudos que enfocam o processo de envelhecimento e analisam a influência de múltiplos fatores que podem interferir na vivência do envelhecimento e da velhice.

No capítulo 2, discorro sobre alguns conceitos da Psicologia Analítica que estão mais interligados com a modalidade de psicoterapia que estou propondo. No capítulo 3, apresento a visão de Jung sobre o seu próprio envelhecimento e suas principais idéias a respeito da velhice, e o enfoque de Hillman, teórico pósjunguiano, para quem é tarefa do idoso desempenhar o papel que os velhos sempre desempenharam: preservar e transmitir o conhecimento e moldar nas defesas da vida real a força do caráter.

No capítulo 4, exponho as condições históricas que propiciaram o nascimento da Psicoterapia Breve dentro da Psicanálise e as contribuições de dois teóricos importantes: Malan e Ryad Simon. No capítulo 5, desenvolvo os conceitos teóricos que fundamentam a prática da Psicoterapia Grupal e da Psicoterapia Breve, a partir dos pressupostos da teoria junguiana.

No capítulo 6 , apresento os objetivos desta pesquisa e, no capítulo 7 , o método empregado.

No capítulo 8, analiso os resultados obtidos por meio do Método de Rorschach. Este método foi utilizado na forma de teste-reteste, isto é, o Rorschach foi aplicado antes do início da psicoterapia e reaplicado após o seu término, visando obter registros psicodiagnósticos que pudessem indicar o funcionamento intelectual 
e a afetividade dos participantes idosos nos dois momentos, para posterior comparação dos resultados. Os estudos de Fiorini e Peyrú (1978) salientam a importância da correlação entre as observações clínicas e os resultados das provas diagnósticas e constatam que a relação entre as avaliações clínicas e psicológicas pode conferir maior rigor metodológico à investigação do processo psicoterápico, enriquecendo seus resultados. Os dados de cada participante foram comparados, com o objetivo de avaliar o nível de evolução individual. A partir do trabalho desenvolvido por Gavião (2002), busquei verificar as características do sujeito coletivo antes e após a intervenção psicoterápica, comparando os resultados. Algumas tabelas foram elaboradas para facilitar a compreensão do leitor não familiarizado com o Método de Rorschach. Ainda neste capítulo apresento a análise das onze sessões, integrando a teoria junguiana com as questões relativas ao envelhecimento e à velhice.

No capítulo 9, discuto os resultados obtidos, procurando refletir sobre a dinâmica entre as observaçõs clínicas e os resultados do Rorschach. A partir dessas integrações, aponto as mudanças que cada participante e o grupo apresentaram em função do processo psicoterápico grupal breve.

Finalmente apresento as conclusões da pesquisa indicando as transformações que ocorreram em cada participante e no grupo no sentido de um crescimento psicológico significativo. 


\title{
CAPÍTULO I
}

\section{O TEMPO DO ENVELHECIMENTO}

\author{
Quando envelhecer vou usar púrpura \\ Com chapéu vermelho, que não combina \\ Nem fica bem em mim. \\ Vou sentar na calçada quando me cansar... \\ ...tocar campainhas \\ e passar a bengala nas grades das praças \\ e compensar toda a sobriedade de minha juventude. \\ Vou... apanhar flores no jardim dos outros \\ E aprender a cuspir... \\ ...agora temos que pagar aluguel, \\ e ser bom exemplo para as crianças. \\ ...Mas quem sabe eu devia treinar um pouco agora? \\ Assim os outros não vão ficar chocados demais \\ Quando de repente eu for velha e usar vestido púrpura.
}

\subsection{Histórico e Conceito de Velhice}

Começaremos agora a percorrer um caminho difícil, que, por ser associado à morte, é muitas vezes negado de diferentes formas.

É como se fôssemos para dentro de um labirinto... o labirinto do tempo do envelhecimento, um tempo que, se for medido por meio de números, nos leva a questionar se já estamos vivendo mais do que as estatísticas e as tabelas de expectativa de vida estabelecem ou não.

Quantos anos me restam viver, se vivo num país em desenvolvimento?

Viveria mais se vivesse num país do primeiro mundo?

A questão não é quantitativa a meu ver...

As pesquisas diariamente divulgadas a respeito das expectativas de vida fornecem números que, ao mesmo tempo em que nos estimulam, tornam-se um peso, pois priorizam a quantidade de anos que ainda podemos viver, mas não se referem ao como podemos vivê-los de forma harmoniosa conosco mesmos.

É importante lembrar que durante séculos a velhice foi associada, não à morte, mas à vitalidade e ao caráter. 
Utilizarei aqui o termo caráter no sentido que Hillman propõe, desligando-o tanto da religião e da ética e moral, como da ciência.

A palavra caráter deriva-se de kharassein, um termo grego que significa "gravar", "esboçar" ou inscrever: kharakter, que é tanto a pessoa que faz marcas aguçadas e incisivas quanto a marca assim feita, como uma letra num sistema de escrita. Caráter refere-se às qualidades distintas de um indivíduo [...]. (Hillman, 2001, p. 23).

E acrescenta que:

Existe um sentimento intuitivo que impede que os seres humanos saiam demais do rumo ou ultrapassem suas fronteiras envolvendose com mundos que não são autênticos na nossa natureza [...] o caráter age como uma força orientadora... ele é feito de traços, imagens, qualidades. Por definição, o caráter refere-se às marcas que o distinguem e que tornam uma coisa reconhecivelmente diferente de todas as outras coisas. Cada caráter se mantém coeso pelas qualidades que Ihe são peculiares (Hillman, 2001, p. 208).

Esse autor complementa afirmando que:

Parte daquilo que quero dizer com "força do caráter" é a persistência das anomalias incorrigíveis, esses traços que não conseguimos consertar, não conseguimos esconder e não conseguimos aceitar [...]. Resta-nos entender que o caráter é realmente uma força que não pode sucumbir à força da vontade nem pode ser alcançada pela graça [...]. O caráter me força a ir ao encontro de cada acontecimento segundo o meu estilo peculiar. Ele me força a diferir. Caminho pela vida estranhamente - ninguém mais caminha como eu caminho, e esta é a minha coragem, a minha dignidade, a minha integridade, a minha moralidade e a minha ruína. (Hillman, 2001, p. 211) [grifos do autor]

Mas o que é velhice? Como podemos conceituá-la? A partir dos vários autores consultados, é perceptível a grande dificuldade em se determinar o conceito de velhice. O processo de envelhecimento nos parece mais fácil de se compreender do que a conceituação da velhice. Esta dificuldade fica visível inclusive na obra clássica de Simone Beauvoir (1970/1986) A velhice, em que esta, ao alinhavar dados históricos de diversas culturas, em diferentes momentos da história da humanidade, busca delinear aquilo que definiria a velhice. Essa autora não diferencia o processo de envelhecimento da velhice, mas deixa claro que esta fase é real para todos e sofre a influência da cultura. 
Beauvoir ao se reportar ao sentido da velhice nas sociedades primitivas constata que algumas tendiam, em função de uma organização social precária, a abandonar seus idosos, enquanto, outras, em função de condições sociais diferentes, os respeitavam e os valorizavam.

Analisando a velhice no curso da história até o século $X X$, em que organizações sociais diversas predominavam, a mesma autora constata a influência da cultura no tratamento dado a essa fase do desenvolvimento humano e aponta que o conceito de velhice só surgiu realmente após a revolução industrial.

Mucida (2004) afirma que a nossa sociedade atual, tal como as sociedades primitivas e menos organizadas socialmente falando, tem formas diferentes, mas não menos cruéis de abandonar os idosos.

$\mathrm{Na}$ atualidade, o idoso encontra diferentes formas de se deparar com o desamparo. Sua história não encontra lugar diante das novidades do mercado, sua imagem não pode acolher como antes as maquilagens (em francês: maquille-âge, maquiar a idade), mesmo com o mercado das próteses e cirurgias plásticas; o limite persiste. (Mucida, 2004, p. 82) [grifos do autor]

Hamilton (2002) também assinala que o envelhecimento não é exclusividade dos tempos modernos e que só nos últimos cem anos se tornou algo comum. Esse autor afirma que nos tempos pré-históricos a velhice era extremamente rara, no século XVII provavelmente apenas $1 \%$ da população vivia mais de 65 anos, e, que, no século XIX, essa proporção subiu para aproximadamente $4 \%$.

\subsection{Um País de Cabelos Grisalhos}

Em 2040, devemos ter cerca de 14 milhões de idosos, antes que a mudança nos índices de natalidade provoque um relativo declínio.

Antes disso, em 2020, afirma Giannetti (2005), "seremos (com sorte) mais de 1 bilhão de pessoas no mundo com idade acima de sessenta anos (dois terços dos quais nos países em desenvolvimento)" (p.40).

Atualmente podemos nos considerar um país de meia-idade com projeção de sermos, nos próximos 40 anos - conforme dados da ONU -, o país mais 
envelhecido do continente latino-americano, considerando-se a população com mais de 60 anos no conjunto da população brasileira.

De acordo com a Organização Mundial de Saúde - OMS (2005), o Brasil até 2025 será o sexto país do mundo com maior população idosa. Esta organização sugere que seja estimulado o envelhecimento ativo que propicia ao idoso melhores condições de saúde, autonomia e produtividade, portanto, que haja condições para um envelhecimento autônomo e com independência.

Dados do IBGE (2005) apontam os 65 anos como a idade a partir da qual a velhice tem início nos países desenvolvidos, e os 60 anos nos países em desenvolvimento. Em 2003, a população de idosos, com idade acima de 60 anos, era de 16,7 milhões de pessoas. O percentual de mulheres era $55 \%$, na faixa etária de 60 a 74 anos, e $58 \%$ acima de 75 anos. A expectativa de vida da população brasileira estava estimada em 71,3 anos. Os homens vivem, em média, 67,6 anos e as mulheres vivem 75,2 anos, o que representa quase oito anos a mais.

Moragas (1999) assinala que o terceiro milênio deve se caracterizar por contemplar o envelhecimento como ativo, com independência e autonomia e, portanto, com qualidade de vida.

Neri (2001), a partir de estudos que evidenciam a longevidade feminina, conseqüência de múltiplos fatores, tais como, menor exposição a fatores de risco que os homens, maior cuidado com a própria saúde, refere-se a esta condição como a "feminização da velhice". Esta condição, no Brasil, muitas vezes não representa vantagem uma vez que a mulher é fisicamente e socialmente mais frágil que o homem e suas condições para um envelhecimento mais digno e saudável dependem muito da classe social a que pertence.

A maior parte dos autores se refere à importância da revisão e da superação dos estereótipos, principalmente os negativos, relacionados à velhice. Os valores da juventude -beleza física, produtividade, agilidade - influenciam na caracterização da velhice como um período de perdas e limitações. Muitas vezes a palavra velho é utilizada como sinônimo de obsoleto, gasto e, nesse sentido, representa grande parte de estereótipo negativo da velhice e é compreensível que se rejeite essa idéia. Messy (citado por Mucida, 2004), a respeito da palavra velho, em francês (vieux), lembra que esta guarda tanto a palavra vie (vida) como o prenome pessoal eux (eles). Mucida (2004) complementa dizendo que a velhice pode, dessa forma, ser 
vivida como um estranho familiar. A idéia é de que velho é sempre o outro no qual não nos reconhecemos.

Beauvoir (1970/1986) assinala que a "velhice tem uma dimensão existencial: modifica a relação do indivíduo com o tempo e, portanto, sua relação com o mundo e com sua própria história" (p. 15). Essa autora pontua ainda que na velhice, a decadência e a finitude são características percebidas mais pelos outros que convivem com o idoso do que por ele próprio. O sujeito, portanto, vê o seu envelhecimento, a sua velhice, pelo olhar do outro ou ele se vê velho pela imagem que o outro lhe devolve.

Maldonado e Canela (citado por Santos \& Diniz, 2006), sugerem uma reflexão importante acerca da diferenciação entre manter a juventude, que contém 0 preconceito de que o bom é ser jovem, e manter a vitalidade - que aponta mais para a necessidade de cuidar da saúde ressignificando valores e metas, mantendo o interesse pela aprendizagem e curiosidade pela descoberta de coisas novas.

Antigamente, e ainda hoje mais especificamente nos povos orientais, os idosos eram considerados os responsáveis pela divulgação e manutenção dos costumes e lendas, verdadeiros guardiões dos valores e das tradições, e suas vozes eram ouvidas e seus conselhos seguidos. Ao contrário, hoje em dia, principalmente no nosso mundo ocidental, o progresso moderno, ao mesmo tempo em que amplia nosso tempo de vida, desvaloriza o idoso, tornando-o sem funções e alijado do convívio social. É como se a importância da velhice estivesse em relação inversa ao progresso...

Que preço alto pagamos pelo progresso!

Beauvoir (1970/1986), já em 1970, observava que as pessoas tinham dificuldade para aceitar e enfrentar as mudanças que ocorriam com 0 envelhecimento, tendendo a se fixarem no antigo eu visando se sentirem imutáveis. O passado para os idosos representa o que é conhecido e lhes dá segurança, enquanto o presente e o futuro são uma incógnita tanto em relação à sua posição na sociedade como à sua identidade.

Mucida (2004) vai mais além ao assinalar que o idoso tende a recordar insistentemente seu passado porque nesse tempo ele era sujeito de sua história e, ao recordar e recontar os passos vividos, ele tenta atualizar o que já foi. Essa autora acrescenta que esse movimento do idoso no sentido de reconhecer-se como 
contador de sua história é fundamental para sua vida e para se fortalecer frente a uma cultura que tende a despojá-lo de sua posição de sujeito desejante.

\subsection{Envelhecendo e se Desenvolvendo}

As alterações que evidenciam o envelhecimento são sentidas por alguns como abruptas, mas, se estivermos atentos, elas se manifestam no dia-a-dia em pequenos atos e pequenas dificuldades, que muitas vezes são racionalizadas e/ou banalizadas. Segundo Campos (2006), o luto que precisa ser elaborado durante o envelhecer é o da própria vida e isso gera nas pessoas um sentimento de difícil adaptação.

A velhice apenas nos acena pequenos traços, pequenos matizes que não formam nunca um quadro tangível; não percebemos o silêncio pelo qual ela marca suas trilhas em nossa imagem, mesmo que as percebamos no Outro. As diferentes marcas deixadas no real do corpo, as construções possíveis de cada um a partir da atualização do que se foi, o trabalho de luto necessário e constante, enfim, as maneiras como cada um conduz o real, tudo isso não deixa dúvida: cada um envelhece de seu próprio modo. Como um quadro, a velhice depende das mãos de seu pintor, da escolha das tintas, do desenho a ser delineado por um olhar que escapa [...]. (Mucida, 2004, p. 16)

Envelhece quem quer? No mundo atual é como se envelhecer fosse uma questão de escolha. A velhice é sentida pela maioria das pessoas como uma doença que precisa ser extinta e, na impossibilidade disto, deve pelo menos ser vencida utilizando-se para este fim todo tipo de "arma", desde medicamentos até cirurgias "milagrosas". Após vencê-la, busca-se o rejuvenescimento acreditando-se que se pode obter o prolongamento da vida e reverter o próprio processo de envelhecimento.

A falta de conhecimento sobre os processos típicos do envelhecimento, durante muitos anos, levou a confundir o que era próprio do envelhecimento e o que era patológico. Muitas vezes sintomas graves eram considerados inerentes à velhice e não uma condição que exigia diagnóstico e intervenção. Berger (2003) a esse respeito considera que o envelhecimento contempla dois processos: a senescência, envelhecimento primário que corresponde ao desgaste corporal natural, e a 
senilidade, envelhecimento secundário, que abarca o aspecto patológico do envelhecimento. Segundo De Vitta (2000), é uma minoria de idosos que apresenta uma velhice patológica.

A pesquisa de Pellegrino-Rosa e Rosa (1997), com 153 idosos, na faixa etária de 50 a 77 anos, procurou contribuir para uma visão do processo de envelhecimento normal do idoso através da obtenção de variáveis afetivas associadas a este processo. São elas: tristeza, pessimismo, grau geral de depressão medido pelo IDB (Inventário de Depressão de Beck), senso de fracasso, insatisfação, culpabilidade e expectativa de punição, e sete variáveis cognitivas: reprodução visual, aprendizagem associativa, controle mental, memória lógica, compreensão, dígitos e nível de escolaridade.

Birman (1995) refere que na atualidade a velhice passa a ser vista como um fracasso pessoal, havendo uma busca maníaca pelo rejuvenescimento. $O$ indivíduo passa a culpar-se diante da sua impotência frente ao próprio declínio e a nutrir sentimentos depressivos e paranóides, uma vez que a vivência da velhice é incompatível com os padrões sociais atuais.

Santos e Diniz (2006) também afirmam que o envelhecer é muitas vezes percebido como uma questão de escolha e de descuido pessoal. Idosos, principalmente mulheres, que durante a vida não tiveram como prioridade programas de rejuvenescimento e um estilo de vida considerado o mais saudável, tendem a se sentir culpados por envelhecerem.

A respeito das perdas advindas do envelhecimento e da necessidade de elaboração do luto, Mucida afirma:

[a velhice] é um momento no qual muitos rearranjos que o sujeito teceu para enfrentar o real desmoronam e com eles muitos dos ideais. Não podemos negar que, apesar de vivenciarmos perdas durante toda a vida, estas são mais freqüentes a partir de certa idade - variável para cada um - impondo elaborações para a construção de outros ideais. (Mucida, 2004, p. 155)

Quando começamos a envelhecer? O termo envelhecimento tem sido utilizado para identificar a passagem do tempo na velhice, mas na verdade envelhecemos desde o nosso nascimento. No ciclo do desenvolvimento humano, a criança cresce e no seu desabrochar, todas as potencialidades se atualizam gradativamente; o adolescente, de forma barulhenta e estouvada vivencia as 
transformações que se operam na sua vida em direção a um maior equilíbrio e completude, e sabemos que as perdas e os lutos vividos logo serão sobrepujados por novas e surpreendentes aquisições.

A trajetória da velhice é diferente. As mudanças tanto corporais como psíquicas operam lentamente a partir, principalmente, da meia-idade, e as novas aquisições vão ser sentidas como satisfatórias ou não, dependendo da sociedade e da cultura na qual o idoso está inserido.

Portanto, a definição do que é e quando somos velhos é muito importante, embora não haja uma resposta conclusiva. Sabemos que a velhice é a última fase da vida que termina com a morte, e que o significado da velhice, como mencionamos acima, está diretamente ligado à cultura e ao tipo de sociedade. Podemos dizer que o envelhecimento se dá como um processo no decorrer da vida: como o indivíduo viveu, assim será a sua velhice.

Giannetti em suas reflexões sobre o envelhecer comenta que:

O termo envelhecer é ambíguo. Ele denota "ficar mais velho", ou seja, a mera passagem dos anos sem qualquer conotação qualitativa de perda de vigor ou deterioração do organismo (uma jovem que atinge a menarca está "ficando mais velha"); mas ele também é usado no sentido técnico de um progressivo declínio das funções corporais, quer dizer, no sentido de avanço de senectude ou senescência. (Giannetti, 2005, p. 31) [grifos do autor]

Cícero (1997), ao caracterizar, a velhice afirma "Ora, sei de muitos que vivem sua velhice sem jeremiadas, aceitam alegremente estar liberados da carne e são respeitados pelos que os cercam. É, portanto, ao caráter de cada um, e não à velhice propriamente, que devemos imputar todas essas lamentações [...]" (p. 11).

A forma, o jeito de cada pessoa envelhecer depende de vários fatores: condições sociais, culturais, econômicas, físicas e características individuais de personalidade. A influência dos hábitos pessoais e a herança genética também podem interferir na vivência do envelhecimento.

Alguns autores (Abraham et al., citados por Gavião, 1997) consideram o processo de envelhecimento como uma das fases num continuum das crises existenciais que mobilizam o indivíduo no sentido de se questionar e crescer. Daí que esse questionamento, decorrente de um processo introspectivo, pode favorecer o desenvolvimento psíquico do idoso. 


\subsection{A Vivência do Envelhecimento nos Homens e nas Mulheres}

Além da vivência do envelhecimento depender de vários fatores, Campos (2006) chama atenção para o fato desse processo ser uma experiência heterogênea, isto é, há formas diferentes de envelhecer e há uma diferença radical entre como os homens e mulheres envelhecem.

Debert (1994) constatou que as mulheres, ao envelhecer, experimentam uma situação de dupla vulnerabilidade e de "difícil solução", com o peso somado de dois tipos de discriminação: ser mulher e ser idosa.

Oliveira (1999) acrescenta que, além do fator fisiológico, fatores de natureza emocional, social, cultural associados à experiência individual têm um peso significativo na forma como as mulheres vivenciam essa fase. Indícios de envelhecimento, tais como cabelos brancos e rugas, em função de fatores sociais e culturais levam a uma desvalorização do corpo feminino e, conseqüentemente, a uma vivência negativa desse período pelas próprias mulheres.

Muitos autores salientam a influência da mídia a respeito de como deve ser a aparência da mulher que envelhece, ressaltando que, de modo geral, entrevistas, propagandas, programas os mais variados tendem a incutir a idéia de um corpo perfeito que vence a velhice. Tal panorama foi explicitado, por exemplo, na Folha Ilustrada, Folha de S. Paulo, dia 18 de fevereiro de 2007, p. E3, quando diretores de teatro e atrizes veteranas brasileiras afirmam que o mercado obriga atrizes mais velhas a tentar parecer mais jovens, por meio de recursos tecnológicos de ponta ou procedimentos cirúrgicos. De modo geral, a presença de rugas e de um corpo compatível com a idade, têm levado essas profissionais ao desemprego e, conseqüentemente, à perda do seu papel social.

Bergen (1999) afirma que a ciência intervém tecnologicamente no corpo humano alterando suas formas, e, paralelamente, intervém simbolicamente nas relações que o idoso desenvolve com sua própria finitude. Podemos assim dizer que o homem é solicitado a buscar um caminho que o leva a retardar o envelhecimento (mito da eterna juventude) e eliminar a morte. Daí que a juventude passa a ser um ideal a ser conquistado e a velhice um problema.

Bassit (2004) chama atenção para a alteração de papéis sociais nesta fase e para a possibilidade de adoecimento das mulheres que tiveram sua identidade 
baseada, principalmente, no papel de mãe e esposa. Py e Scharfstein (2001), ao contrário, constataram que muitas mulheres, livres dos afazeres domésticos e com filhos já adultos, passam a desenvolver novas atividades fora de casa e a criar novos relacionamentos.

Ruschel (1998) aponta para diferenças importantes na vivência do envelhecimento nos homens e nas mulheres, salientando que para estas últimas as transformações são vivenciadas através do corpo, tendendo a depreciá-lo, enquanto para os homens o marco é a aposentadoria, que também tem efeitos prejudiciais na elaboração do envelhecimento masculino. Py e Scharfstein (2001) assinalam que as mulheres, a partir dessa vivência de um corpo desarmonioso e sem o vigor da juventude, tendem a se sentir discriminadas socialmente.

\subsection{O Envelhecimento e os Papéis Sociais}

G. Zimerman (2005) refere que a perda de papéis sociais para o idoso, tanto homem como mulher, acarreta crise de identidade, mudanças de papéis na família e na sociedade, restrições à independência e à autonomia e diminuição das oportunidades de relacionamento com outros. Tais mudanças são consideradas estressantes e afetam o equilíbrio psicológico do idoso.

Papalia e Olds (2000) afirmam que mudanças significativas na vida do idoso, como perda do papel profissional e perda de convivência com os amigos do trabalho, o casamento ou a vida independente dos filhos e as limitações para assumir novos papéis sociais podem acarretar sentimento de inutilidade, fracasso, de ter que ceder seu lugar para ao mais jovens e esperar a morte.

Mucida (2004) analisa o papel social do idoso e observa a existência de três tipos de idosos: o idoso, que ainda está inserido no mercado como consumidor de bens, é aquele que, geralmente, é absorvido pela indústria farmacêutica e cosmética e luta de todas as formas para apagar as marcas do tempo e preservar uma imagem imutável; os aposentados, que estão fora do mercado, e que nutrem sentimento de vazio e se sentem um fardo social e alijados da vida, e outros que, de alguma forma, estão inseridos no mercado e participam de clubes ou universidades da Terceira Idade, buscando laços sociais e projetos de vida. 
Berger (2003) relaciona a atividade do idoso e suas relações interpessoais. Este autor cita duas teorias importantes a respeito das relações interpessoais na velhice: a teoria do desencargo, criada por Cumming e Henry em 1961, que relaciona a perda do papel profissional com o empobrecimento das relações sociais e considera esse fato inevitável e universal, e a teoria da atividade, criada por Harlow e Cantor em 1996, que relaciona a atividade do idoso a uma maior longevidade. Esta última teoria revela que o estar em atividade traz benefícios tanto físicos como psicossociais.

Para Neri (2001), as relações sociais na velhice, especialmente com colegas da mesma geração, promovem o bem-estar dos idosos, tendo em vista que atendem de forma mais direta às necessidades afetivas dos envolvidos.

\subsection{A Idéia do Tempo na Velhice}

A partir de diferentes teóricos, podemos observar as mais peculiares estratégias que o idoso utiliza para lidar com o tempo.

Goldfarb (1998) a respeito do tempo afirma que entre o nosso nascimento e a nossa morte temos o tempo vivido que é subjetivo e contempla a formação da nossa personalidade. O tempo do envelhecimento está ligado à concepção de finitude que já existe no indivíduo durante toda a sua vida, mas na velhice essa visão adquire a dimensão da realidade e com a proximidade da morte assume uma amplitude incalculável.

A mesma autora complementa:

A "experiência temporal" é própria do ser humano, já que ele é o único ser vivo a se reconhecer finito e a organizar sua vida em torno desta realidade. Esta idéia do tempo se constrói sobre a ilusão de uma sucessão interminável de instantes. Neste constante fluir, cada acontecimento, cada experiência significativa deixa sua marca que guardará uma relação da causalidade com um acontecido antes e com um efeito posterior. (Goldfarb, 1998, p. 67) [grifos da autora]

Quanto ao sentido do envelhecimento Bacelar (citado por Campos, 2006), fala sobre o tempo exterior, inexorável, e o tempo interior que pode contemplar tanto 
perdas quanto ganhos. Ambos não se excluem, mas as transformações decorrentes do envelhecimento podem ser a base para um maior crescimento psicológico.

Bobbio (1997) afirma que a dimensão na qual o velho vive é o passado. O tempo do futuro é para ele breve demais para dedicar seus pensamentos àquilo que está por vir. A velhice dura pouco e deve ser aproveitada para "tentar entender, se pudermos, o sentido ou a falta de sentido de nossa vida" (p. 30). Para esse autor, pensar o processo de envelhecimento e a velhice só a partir de determinantes biológicos significa negar a ação integrada dos muitos fatores sociais, culturais, psíquicos e existenciais, entre outros, que acompanham o ser humano. Assim, a velhice deve ser considerada como totalidade.

\subsection{O papel dos Avós}

Um outro aspecto do papel do idoso se refere ao seu papel de avô (avó). $\mathrm{Na}$ contemporaneidade, o conceito de família assume dimensões novas pois a dinâmica e as estruturas familiares sofrem continuamente alterações decorrentes da separação ou divórcio dos pais e dos novos casamentos. Dentro dessas mudanças, o papel dos avós também se altera.

De acordo com Aratangy e Posternak (2005), a imagem de idoso está diretamente relacionada à imagem de homem que uma determinada sociedade tem. As autoras em sua retrospectiva sobre como os avós têm sido percebidos ao longo do tempo observaram que este papel tem sido relacionado com a velhice e com a morte. Hoje em dia, constatam essas estudiosas, tem havido alteração dessa imagem no sentido de avós que mantêm uma atividade profissional e são socialmente ativos.

Essa mudança no papel dos avós está atrelada a fatores sócio-históricoculturais e familiares, e em função dessas influências ainda se mantém na nossa sociedade o papel de avós cuidadores, que se propõem a zelar pelos netos para que os filhos trabalhem.

A influência dos avós nos netos (Falcão, Dias, Bucher-Maluschke \& Salomão, 2006), pode ser positiva, quando atuam como suporte emocional e fortalecem a autoridade dos pais favorecendo o desenvolvimento do neto em todas as áreas 
vitais, e negativa quando interferem na educação que os pais dão à criança e propiciam que problemas transgeracionais se perpetuem. Essas autoras ainda consideram que o exercício de ser avô traz benefícios para o próprio idoso, pois o contato com o neto representa estar em contato com a própria continuidade e de atuar de uma forma melhor do que atuou como pai/mãe. Esse exercício possibilita também que o idoso se reavalie e se realize.

Aratangy e Posternak (2005) apontam que, independente da influência ser positiva ou não, a presença afetiva dos avós geralmente representa um elo positivo da criança com o mundo que a cerca, inclusive com o envelhecimento e com a morte.

\subsection{O idoso e a Sexualidade}

A questão da sexualidade na velhice merece uma atenção especial. Nossa cultura prescreve a busca do prazer e para isto temos as pílulas milagrosas, os cursos e contatos via internet que ensinam como ter prazer sem parceiro e de formas alternativas, uma vivência da sexualidade sem limites e solitária. Será essa a única saída para o sexo na velhice?

Freud (1905/1972), em sua obra Os três ensaios sobre a teoria da sexualidade afirma que não existem regras sexuais, mas regras sociais, e que a libido não tem idade, estando presente durante toda vida do sujeito.

[...] não é a idade que determina a ausência do desejo e, muito menos, a ausência ou a presença de relações sexuais mesmo que estas possam ser inscritas na velhice sob tecidos diferentes daqueles encontrados na adolescência e na vida adulta, nos quais computar os orgasmos é uma forma usual. A sexualidade do idoso pode encontrar caminhos inéditos nos quais o desejo, que não morre, encontra outras maneiras de inscrição. (Mucida, 2004, p. 41)

Terhorst, Castro e Guerra (1998) afirmam que há muito preconceito em relação à sexualidade do idoso, este tendendo a encará-la como imprópria e desajustada. Essas autoras chamam atenção para essa visão preconceituosa e destrutiva que a nossa cultura propaga e afirmam que a capacidade de sentir prazer perdura por toda vida, não sendo exclusiva da juventude e da vida adulta. 
Pellegrino-Rosa e Rosa (1997) em seu trabalho sobre a sexualidade na terceira idade, concluíram que experiências na infância com uma boa figura paterna têm um peso significativo no desenvolvimento de uma sexualidade saudável na velhice, tanto para o homem quanto para a mulher.

Bacelar (citado por Campos, 2006), constata que as mulheres sofrem mais do que os homens as conseqüências da visão errônea difundida culturalmente sobre a sexualidade no processo de envelhecimento.

Mucida (2004) assinala que o envelhecimento na mulher tem um marco importante que é a menopausa, a qual, muitas vezes, é associada à perda da libido sexual. As modificações corporais e hormonais importantes dessa fase foram e ainda são tomadas como uma patologia geral, na qual há uma associação errônea entre menopausa e perda de valor, a mulher passando a ser vista como frágil, dessesxualizada, vulnerável frente a muitas doenças.

Se a menopausa é ou não valorizada em conformidade com o discurso dominante, é certo que numa cultura que cultua semblantes de novo, de beleza, de performance - dentre outros, a menopausa sinalizará o fracasso da ciência em deter aquilo que insiste em se inscrever apesar das promessas milagrosas de infindáveis objetos [...]. Quando a ciência se detém a falar da menopausa, seu discurso não almeja outra coisa: controlá-la e silenciá-la. Não obstante a reposição hormonal, controlando muitos dos efeitos da menopausa, não se pode anular a incidência desse significante sobre os sujeitos. (Mucida, 2004, p. 163)

Essa autora ainda assinala que tanto a menopausa como o climatério são momentos em que pode advir angústia em função do luto inerente às modificações mencionadas acima. A frustração pela necessidade não satisfeita e a dificuldade do idoso de encontrar novas formas de se satisfazer, mais adequadas às novas exigências da realidade, bem como a inibição do desenvolvimento e um aumento libidinal - o qual deve ser entendido como uma exigência pulsional que em função das mudanças corporais exige novas formas de expressão - perturbam o equilíbrio e podem gerar angústia.

Apesar das discussões a respeito de uma possível andropausa ser ainda inusual, a ciência reconhece que existem mudanças também hormonais incidindo sobre o corpo masculino. 
Não se pode, pois, desconsiderar que, embora não haja na andropausa os mesmos caminhos de impedimento à reprodução que a menopausa impõe à mulher, há um período similar para os homens com efeitos também particulares à forma de se exprimir da sexualidade masculina. (Mucida, 2004, p. 169) [grifo da autora]

Ainda a esse respeito, Mucida (2004) menciona Freud quando este, em seu texto Sobre os critérios para destacar da neurastenia uma síndrome particular intitulada neurose de angústia se reporta à angústia de senectude, como decorrente da dificuldade de controle sobre a excitação somática.

\subsection{Aids na Velhice}

A vivência da sexualidade na velhice, e de como esta pode ser vivida de forma saudável, tem hoje em dia esbarrado numa questão crucial que é a da Aids nessa fase da vida.

Saldanha, Araújo e Felix (2006), utilizando dados do Ministério da Saúde referentes a 2005, constataram que há um crescente número de casos de Aids na faixa etária acima de 50 anos. No Brasil, são 30.827 casos em maiores de 50 anos, sendo 8.339 em pessoas com 60 anos ou mais. Esses dados, com certeza, se distanciam da estatística real em função de fatores como notificações tardias, escassez de pesquisas, diagnósticos incorretos etc.

Lieberman, (citado por Saldanha, Araújo \& Felix, 2006) relaciona o crescente número de casos de Aids na velhice à prática de relações sexuais desprotegidas. 0 homem, usufruindo os recursos da medicina, como o Viagra, e a mulher, livre do risco de gravidez, não se preocupam em utilizar preservativos que os protejam de doenças sexualmente transmissíveis e da Aids.

Podemos pensar que, para os idosos, a possibilidade de ser infectado é considerada remota, em função de valores sociais e culturais introjetados anteriormente. A publicidade veiculada não abrange informações sobre a necessidade de prevenção nessa faixa etária, e podemos inclusive pensar que isto se deve também a uma atitude preconceituosa em relação à vivência da sexualidade na velhice. 
Saldanha, Araújo e Felix (2006) constataram que a Aids acarreta mudanças significativas no modo de viver do idoso, intensificando sentimentos de inadequação, medos e preconceito (o próprio e o do meio). As autoras apontam para a necessidade de orientação às famílias dos idosos infectados, bem como a criação de grupos de auto-ajuda para lidar com a complexidade que está contida no envelhecimento com Aids.

\subsection{Velhice e Morte}

A relação entre velhice e morte exige também uma reflexão cuidadosa. A qualidade de vida do idoso está relacionada a vários fatores já mencionados no decorrer deste trabalho, mas não há dúvida de que é muito influenciada pela atitude deste frente às perdas no decorrer de sua vida, principalmente àquelas inerentes ao processo de envelhecimento e à consciência da finitude.

Antigamente a doença e a morte faziam parte da nossa vida. As famílias, ou viviam sob o mesmo teto ou próximas umas das outras, se visitavam com freqüência, cuidavam dos seus idosos e acompanhavam seu envelhecimento dia-adia, acolhendo-os de todas as formas. Não era um mundo perfeito, conflitos intergeracionais existiam, mas predominava a participação direta dos familiares na evolução das doenças e na preparação para a morte do ente querido.

Atualmente, nos afastamos da doença e da morte como se estas não fizessem parte da vida humana. Na nossa cultura, a doença e a morte devem ficar restritas aos hospitais e às UTIs, repletas de instrumentos e aparelhos de última geração, onde os idosos morrem sozinhos como se fossem apenas um ser dotado de um corpo meramente biológico.

Hoje a doença e a morte foram tiradas de casa para os hospitais. Profissionais de saúde cuidam dos doentes. Parentes e amigos tornaram-se meros espectadores, olhando algo que acontece sem um fluxo contínuo de emoções e experiências com as quais podem aprender. Em cada família se desenvolve uma ecologia de crenças que se torna a base do sentir, pensar e agir de cada um dos seus membros. Também neste caso as crenças moldam o modo como os familiares se adaptam à doença terminal... (Frankel, 2002, pp. 6667) 
De acordo com essa autora, o término, a finitude é o preço que pagamos por ter começado, e só temos condições de avaliar a importância do começo quando temos a consciência do fim.

Frankel (2002), a partir das considerações de Boadella, relaciona a existência de diferentes tipos de luto: o luto frio traz sensação de escuridão e desespero e o luto quente que contempla sentimentos de paz e gratidão e um temor respeitoso perante a morte. Segundo essa autora, as escolhas pelo tipo de luto estão relacionadas à forma como o idoso viveu a sua vida, e como as "pequenas mortes" foram experienciadas e compreendidas. A integração dessas experiências vai gradativamente preparando o indivíduo para lidar com a "grande morte".

Mucida (2004) refere que na velhice o fantasma da finitude fica escancarado através das diferentes mudanças corporais, e seu poder se amplia frente à limitação dos recursos simbólicos do idoso. Para esta autora, o medo da morte está diretamente relacionado à perda do investimento libidinal e à morte do desejo. Essa mesma autora afirma "Morte e luto, fracasso e perda fazem parte da estrutura da vida e, portanto, acompanham o sujeito. Por paradoxal que seja, porque há morte é que sabemos da vida [...]" (p. 145).

De acordo ainda com Mucida, na medida em que o indivíduo envelhece as perdas se tornam mais freqüentes, e a necessidade de acompanhar a morte dos que Ihe são caros, exige a elaboração de diversos lutos, o que, muitas vezes, excede os próprios limites e acarreta depressão. A reinvenção da vida, para muitos idosos, é difícil e estes tendem a comportamentos regredidos, geralmente ineficazes, e lamentações e queixas que revelam a dificuldade com o trabalho de luto.

A respeito da morte, Freud diz:

Se tomarmos como verdade que não conhece exceção o fato de tudo o que vive morre por razões internas (tornar-se mais uma vez inorgânico), seremos compelidos a dizer que o objetivo de toda vida é a morte. (Freud, 1920/1976, p. 56)

Morato (1992), em uma homenagem póstuma à profa. Rachel Rosenberg, apresenta um texto de autoria desta última a respeito do envelhecimento e morte. Neste, vida e morte não são consideradas coisas separadas, mas fazem parte de um mesmo processo em que transformações diversas operam em todos os níveis 
dentro do universo. Para essa autora, o medo da morte não caminha de forma linear com a idade, havendo um grau diferente de medo da morte em momentos individuais de cada pessoa. A preocupação com a morte seria maior nas pessoas mais insatisfeitas com a própria vida e distanciadas do seu valor espiritual. Aquelas pessoas, cuja busca espiritual traz respostas satisfatórias para suas principais questões existenciais, teriam melhores condições de lidar com o envelhecimento e com a morte.

Essa autora ainda assinala que uma forma saudável de envelhecer e de lidar com a morte está diretamente relacionada à possibilidade de o indivíduo transformar seu mundo conhecido e, muitas vezes estreito (filhos, casa, rotina etc.), e ampliar sua visão de realidade, tornando-se mais independente desses fatores e com interesses mais diversificados.

\subsection{Envelhecimento e Depressão}

O processo de envelhecimento populacional em curso no país tem aumentado a freqüência de doenças psiquiátricas, entre as quais, a depressão. Esta é a desordem mais comum nesse segmento etário, e, quando crônica, acarreta a elevação da probabilidade de desenvolvimento da incapacidade funcional.

Em geral as mulheres são mais propensas a desenvolver depressão por viverem mais e dessa forma adoecerem mais.

Leite, Carvalho, Barreto \& Falcão (2006), em pesquisa com 358 (312 mulheres e 46 homens) idosos, de 60 a 80 anos, que freqüentavam um Programa Universidade Aberta à Terceira Idade, identificaram a presença de depressão em 86 participantes, a maioria do sexo feminino. Os pesquisadores consideraram o índice obtido elevado e encontraram significância estatística de associação da depressão apenas com a variável escolaridade. A correlação com a faixa etária revela que a maioria de idosos deprimidos estava no grupo de idosos entre 70 e 79 anos.

Nesse grupo de idosos deprimidos os autores observaram sentimentos de preocupação e insatisfação, perda de interesse ou satisfação pelas coisas, muitos revelando sensação de tristeza e diminuição da capacidade física para atividades rotineiras. 
Gil (2005) em seu trabalho sobre a relação entre envelhecimento e depressão questiona a existência do estado depressivo como conseqüência natural do envelhecimento. Essa autora assinala que a depressão deve ser entendida como "demanda de sofrimento do ser humano e que pode, portanto, atingir a todos, em qualquer nível de idade" (p. 163) e que a depressão do idoso, na verdade, esconde o quanto ele está afastado da sua subjetividade, despersonalizado e ausente de si mesmo. A partir dessa visão, a depressão é colocada pela autora como tendo um valor importante ao sinalizar a necessidade de integração dos aspectos dissociados do self, e o processo terapêutico, no caso, as consultas terapêuticas, pode ser um meio valioso para o idoso retomar um caminho criativo e integrado de crescimento. 


\section{CAPÍTULO II}

\section{ALGUNS CONCEITOS DA PSICOLOGIA JUNGUIANA}

A psique pertence ao âmago do mistério da vida. Jung

\subsection{A Visão de Homem e de Mundo}

Jung, sem dúvida nenhuma, foi um pensador diferenciado, suas idéias originais e ousadas representam contribuições altamente significativas para a compreensão do fenômeno psíquico.

A influência da teoria de Jung sobre o desenvolvimento da prática psicoterápica e sobre diferentes campos da ciência confirma o seu caráter pluralista e ao mesmo tempo profundo.

A busca de Jung sempre esteve apoiada numa visão singular de mundo e de ser humano.

Sendo assim, não é o universal e o regular que caracterizam o indivíduo, mas o único. Ele não deve ser entendido como unidade recorrente, mas como algo único e singular que, em última análise, não pode ser comparada, nem mesmo conhecida. [...] (Jung, 1967/1998, par. 495)

O ser humano, para Jung, caracteriza-se essencialmente por ser um ser simbólico que vive numa dimensão simbólica que contém o biológico, ambiental, cultural e o psicológico. Na mesma obra Jung (p. 528) refere que a psique contém o fenômeno da consciência, sem o qual "não pode haver o mundo, pois este existe como tal enquanto reflexo e expressão de uma psique consciente. A consciência é uma condição do ser". [grifos do autor]

A respeito das determinantes psicológicas do comportamento humano, Jung (1971/1984) afirma que os instintos representam fatores psíquicos que desempenham um papel determinante nesse comportamento e, quando psiquizados, constituem-se na chave compreensiva da própria civilização.

A alma humana vive unida ao corpo, numa unidade indissociável, por isto só artificialmente é que se pode separar a psicologia dos pressupostos básicos da biologia [...] Os fatores psíquicos que 
determinam o comportamento humano são sobretudo os instintos enquanto forças motivadoras do processo psíquico. [...] $\mathrm{O}$ instinto como fenômeno psíquico seria, pelo contrário, uma assimilação do estímulo a uma estrutura psíquica complexa que eu chamo de psiquificação. (Jung, 1971/1984, par. 232-234) [grifos do autor]

Na mesma obra, Jung refere a existência de cinco grupos de instintos: instinto de auto- conservação (fome e sexo), o impulso à ação, o instinto criativo e o instinto da reflexão. Este último inclui o instinto cultural e é responsável pela criação da consciência.

Esse instinto de reflexão assume um papel fundamental no controle e no ajuste da própria natureza instintiva, favorecendo dessa forma o fortalecimento da consciência e, portanto, a construção da civilização.

Jung considera que a nossa civilização está em transição, cabendo ao homem - através da forma como ele lida com a cultura - fazer as necessárias transformações e desenvolver seu potencial de tornar-se o que é, e com isso participar do coletivo de uma forma viva e diferenciada.

A ênfase que o conhecimento científico deu à matéria e à divisão corpo-mente foi o que mobilizou Jung a desenvolver uma teoria que buscasse a compreensão sintética da matéria e da psique, partindo da visão unificada do ser humano e do mundo, e do diálogo entre o consciente e inconsciente. Penna (2003) assinala que o mundo, para Jung, incluiria o meio sócio-histórico-cultural e seria designado de consciência coletiva, mas também abarcaria o inconsciente, ambiente interno, que incluiria sonhos, imaginação, imagens tanto as pertencentes à esfera pessoal como as pertencentes à esfera coletiva. Mundos interno e externo não seriam realmente distintos, mas, ao contrário, complementares.

Essa mesma autora lembra que Jung fez um contraponto à visão racionalista do século XX e introduziu uma forma de pensar diferenciada que enfatiza uma visão do mundo e do homem como uma totalidade, e se baseia numa visão construtiva e na busca do sentido da vida. O homem, na Psicologia Analítica, é concebido como uma totalidade que contém aspectos herdados e inatos, assim como adquiridos na sua relação com o mundo que o cerca. O termo si mesmo designa a totalidade humana, abrangendo o humano arquetípico, o que há de original e de eterno no homem, e, ao mesmo tempo, a personalidade individual.

A respeito da visão construtiva, Jung (1960/1976) esclarece que utiliza esse termo de forma paralela a sintético, referindo-se a construtivo como estruturado e 
como um método oposto ao método redutivo. O método construtivo de Jung abrange elaboração e atividade dos produtos inconscientes, quaisquer que sejam eles.

$\mathrm{Na}$ verdade, a Psicologia Analítica vem ao encontro daqueles que, conforme diz Maroni (1998), "estão doentes devido à falta de sentido e conteúdo de suas vidas, os que sofrem uma espécie de doença que Jung denominou 'neurose contemporânea generalizada'. Ou seja, a psicologia analítica é efetiva nos casos em que os recursos do consciente esgotaram-se" (p. 126). Nesses casos, só a força do inconsciente pode indicar saídas e possibilitar a cura através da transformação do indivíduo, da sua individuação.

Para Jung, o homem está inserido e, ao mesmo tempo, é produto da civilização, dos acontecimentos históricos, dos costumes, das religiões. No caso do homem ocidental, este é percebido e identificado com a função pensamento e com o ego, tal identificação unilateral acarretando a anulação das demais funções e prejuízo ou mesmo incapacidade de simbolização. Este quadro revela a tragédia do homem moderno que, com sua excessiva racionalidade e na ânsia de controlar o mundo, afasta-se da alteridade e do processo de simbolização, e, portanto, da possibilidade de individuar-se.

Maroni (1998) refere que o homem individuado não é um homem mais adaptado, mais equilibrado, não é um homem com características especiais.

O homem individuado, após uma longa e intensa vivência psicológica, alcança uma nova morada, um novo ethos, uma nova subjetividade, não raro muito mal compreendida.[...] Individuar-se, diferenciar-se da cultura em que estamos inseridos e da qual somos, até certo ponto, o produto significa tornar consciente a imagem do mundo e de si mesmo, saber o que o mundo é e o que eu sou. (Maroni, 1998, pp. 24-25)

\subsection{A Realidade Psíquica e o Conceito de Psique}

Quanto à noção de realidade psíquica, Jung, segundo Penna (2003), sempre a considerou tão real como a realidade física, o mundo interior formando uma unidade viva com o mundo exterior e ambos sendo igualmente importantes e fundamentais para a criação da realidade do ser humano. 
A respeito do conceito de personalidade, muitas vezes Jung a define como sinônimo de psique e como a soma do consciente e do inconsciente. Em sua essência, a psique contém tudo interligado: os fenômenos intrapsíquicos, os somáticos e os interpessoais, em suma, todos os níveis da existência e da experiência estão intimamente ligados, havendo um continuum espaço-tempo.

Minha vida, impregnada, tecida, unificada por uma obra, foi centrada num objetivo: o de penetrar no segredo da personalidade. Tudo se explica a partir desse ponto central e toda a minha obra se relaciona com esse tema. (Jung, 1961/1988, p. 182)

Jung (1956/1985), neste sentido, refere-se ao unus mundus, termo retirado da filosofia medieval, que significa a unidade original indiferenciada, na qual mundos físico e psíquico são uma totalidade e o tempo uma unidade que contém passado, presente e futuro. Daí a possibilidade de existência de coincidências significativas entre eventos, fora da concepção das leis naturais e das relações entre causa e efeito.

Emprego, pois, aqui, o conceito geral de sincronicidade, no sentido especial de coincidência, no tempo, de dois ou vários eventos, sem relação causal, mas com o mesmo conteúdo significativo, em contraste com "sincronismo" cujo significado é apenas o de ocorrência simultânea de dois fenômenos. (Jung, 1971/1984, p. 459)

A partir dessa idéia de interligação entre todo tipo de fenômeno é que Jung elabora a sua teoria sobre a estruturação da psique e a sua dinâmica.

A psique abrange a totalidade dos processos psíquicos, tanto da consciência como do inconsciente, cada parte completando a outra e também atuando de forma compensatória. A consciência se desenvolve a partir do inconsciente e do contato com a realidade exterior, tendo o ego como seu centro e responsável pelo sentido de continuidade e identidade.

A estrutura da psique contempla um nível individual - a psique pessoal - e o nível coletivo - a psique objetiva ou coletiva. A psique pessoal abrange o inconsciente pessoal, a consciência, o ego como centro desta e os complexos. Da força egóica depende a qualidade da integração entre os processos inconscientes e conscientes, e a própria integração obtida repercute num maior fortalecimento do próprio ego. 


\subsection{O processo de Individuação}

A idéia da individuação aparece em vários autores desde os antigos filósofos gregos, mas nenhum deles focou os aspectos inconscientes desse processo como o fez Jung.

A individuação significa tender a tornar-se um ser realmente individual; na medida em que entendemos por individualidade a forma de nossa unicidade, a mais íntima, nossa unicidade última e irrevogável; trata-se da realização de seu si mesmo, no que tem de mais pessoal e de mais rebelde a toda comparação. Poder-se-ia, pois, traduzir a palavra "individuação" por "realização de si mesmo", "realização do si mesmo". (Jung, 1961/1988, p. 355) [grifos do autor]

Maroni (1998) ressalta que a "tarefa da individuação é restabelecer o todo (psíquico) a partir de duas metades incongruentes o ego-consciência e 0 inconsciente" (p. 98), esse processo sendo marcado pelo conflito entre essas duas partes. Após o conflito, a meta é sempre a união entre consciente e inconsciente, portanto, uma síntese continuamente crescente entre essas duas polaridades.

Essa autora assinala que os momentos típicos do processo de individuação podem ser resumidos nos seguintes tópicos: o confronto, a diferenciação e a integração dos conteúdos da sombra; a integração dos conteúdos da anima ou do animus; o desenvolvimento de uma nova relação entre o ego e o self.

Maroni (1998, pp. 99-120) destaca também os cinco pontos inter-relacionados no processo de individuação:

1. o tema do sacrifício que, em sua essência, alude à inversão da direção da libido. "Com o sacrifício, determinada organização da consciência será interpelada; determinada hierarquia (instintual/arquetípica) será posta em questão; a relação mesmo da consciência e do inconsciente será redefinida" (p.100). A noção de sacrifício está baseada na existência de um processo contínuo de construção e destruição, de morte e vida, momentos esses que são o cerne do processo de transformação da personalidade;

2. o diálogo entre as "figuras da imaginação" - Jung, a partir da introspecção, propõe o estabelecimento de uma relação e diálogo com as figuras da imaginação/complexos/personalidades parciais, chamando atenção para o fato de que não é o ego/consciência que determina qual figura deve vir à consciência, mas sim o inconsciente é que deve decidir. Jung sugere que se preste atenção às fantasias e aos sonhos que emergem, partindo do fato que essas figuras da imaginação têm 
autonomia própria e que há uma objetividade psíquica. A relação e o diálogo com as figuras da imaginação não resultam em esgotamento dessas figuras, ao contrário, implicam animação. Ainda é importante ressaltar que, ao confrontar-se com as figuras da imaginação, o complexo do eu tem que diferenciar-se delas, com responsabilidade, e se possível realizá-las, sem perder de vista a ética.

3. a relação ego/self - Na obra A natureza da psique, Jung (1971/1984) afirma que durante o processo de individuação, na medida em que há diferenciação dos conteúdos inconscientes e diálogo com as figuras da imaginação, há também transformação da personalidade consciente, isto é, se a estrutura do complexo-do-ego é suficientemente forte, o afluxo de conteúdos inconscientes enriquece e vitaliza a personalidade, a vontade consciente fica subordinada ao self, sem, contudo se deixar ser assimilado por essa nova figura-da-totalidade. Ego e self devem preservar suas peculiaridades e manter seus papéis visando a manutenção do diálogo consciente-inconsciente.

4. a individuação e a criação de valores - Jung afirma que, pelo fato de o processo de individuação implicar uma reorganização da libido, essa transformação implica também um rompimento com a tradição cultural. Maroni explica que a evolução psíquica, para a Psicologia Analítica, "pressupõe a emancipação do indivíduo das regras coletivas e o respeito a sua própria lei [...] Do ponto de vista psicológico, ou seja, do indivíduo, a igualdade é a inconsciência: os indivíduos são iguais somente na medida em que são inconscientes [...]" (pp. 114-115). Na medida em que o homem se emancipa das regras coletivas, ele está no caminho para atingir o que os alquimistas denominavam opus alquímico, e este processo possibilita que o homem individuado produza novos valores para a sociedade.

5. a fantasia ativa e a busca do reino intermediário - A fantasia ativa, a imaginação criadora é a meta de individuação, e é resultante do entrelaçamento dialético e da unidade de todos os opostos, a síntese deles. Jung (1974/1993) refere que a união da verdade racional com a verdade irracional está contida no símbolo, que é vivo, transforma energia, contém em si um arquétipo, um núcleo significativo, indivisível, mas carregado de energia. A natureza do símbolo faz com que ele não possa ser explicado racionalmente, com o risco de ser destruído, mas sim compreendido. Maroni (1990) assinala que "Após o longo trabalho de diferenciação e integração das fantasias coletivas desses complexosarquétipos, eles não se hierarquizam nem desaparecem, mas despotencializam-se" (p. 119). Essa nova subjetividade, resultante da unidade dos opostos em princípio elimina os opostos, mas as necessidades de adaptação ao mundo externo fazem com que um novo ciclo de tipos e funções psíquicas especializadas se desenvolva até um ponto em que novas integrações e sínteses sejam ativadas. É justamente essa a característica essencial do processo de individuação: um processo constante de produção de novas sínteses, de integração contínua de conteúdos inconscientes, que gera uma síntese sempre crescente entre consciente e inconsciente.

É importante ressaltar que embora tudo esteja interligado, durante o desenvolvimento psíquico - para que este ocorra - é preciso haver discriminação da realidade e reconhecimento das próprias projeções e mecanismos do mundo interno.

Só a partir dessa etapa de diferenciação sujeito-objeto, possível graças ao 
desenvolvimento do ego, é que pode fluir um movimento novamente em direção à unificação, à totalidade, o si mesmo. Esse fluxo é parte do processo de individuação da psique.

Muitas vezes, a idéia de individuação é criticada como tendo um cunho individualista.

\subsection{A Prática Psicoterápica}

\subsubsection{Princípios Básicos da Análise Junguiana}

Em relação ao processo psicoterápico e ao modo como este possibilitaria o movimento em direção ao si mesmo, Jung propôs vários princípios que revolucionaram a prática psicanalítica da época.

Afirmava que em psicoterapia o essencial não consistia em apenas aplicar um método e que os conhecimentos técnicos não bastavam, sendo a condição essencial da formação do analista a sua própria análise. Jung enfatizava que todo psicoterapeuta não só tem seu método, mas ele é esse método, e que sua qualidade humana é fundamental e só pode existir se for atrelada à sua atitude ética.

Além do autoconhecimento e da supervisão, Penna aponta outras características que o analista deve apresentar

A apreensão de material inconsciente demanda do observador certas habilidades que vão além da acuidade perceptiva e perspicácia intelectual, exigindo sensibilidade e empatia com o sistema observado. A esfera intelectual é insuficiente como instrumento de captação dos fatos observados. Ou seja, todas as funções da consciência (sentimento, pensamento, sensação e intuição) devem estar disponíveis para o sistema observador ser capaz de captar de forma abrangente o fenômeno psicológico. (Penna, 2003, p. 174) 
Jung (1971/1981), diferentemente da prática psicanalítica, propôs que o atendimento fosse face a face e considerava a psicoterapia um tipo de procedimento dialético, em que o diálogo entre analista e paciente se caracteriza como um sistema psíquico atuando um sobre o outro. Assinalava a necessidade de um confronto entre as averiguações de ambos e que este confronto só poderia acontecer se o analista deixasse de lado seus próprios pressupostos, e desse condições para que o paciente apresentasse seus conteúdos o mais livremente possível.

[...] [Jung] foi o primeiro a enfatizar o fato de que o desenvolvimento é interrompido não apenas por causa de traumas passados, mas também pelo simples medo de dar os passos evolutivos necessários. Ele dava mais ênfase não aos desejos reprimidos, mas aos eventos de vida em curso como precipitantes da regressão vivida na análise. O material oriundo desta regressão era usado para trazer o paciente de volta à realidade com uma nova orientação que pudesse ser aplicada na prática. (Salman, 2002, p. 71)

Essa possibilidade de integrar a tendência causalista à finalista, faz com que a psicoterapia analítica, segundo Penna (2003), possa abarcar tanto a interpretação analítico-redutiva, característica da psicanálise, como a concepção sintética ou analógica.

Maroni (1998) assinala que o objetivo da psicoterapia analítica é "alcançar um estado psíquico de fluidez, mudança e crescimento em que nada está eternamente fixo e, menos ainda, petrificado" (p. 128).

Esse estado de individualização progressiva inclui uma questão importante que é a do papel do tempo no tratamento psicoterápico. Jung (1971/1981) refere que "este método [a psicoterapia analítica] atribui ao tempo uma importante função na cura" (par. 43).

Laureiro (1986) lembra que Kronos, cujo nome significa "tempo", diferentemente de Kairós, "está subjacente à nossa percepção do passado, presente e futuro, ou seja, à nossa orientação no tempo. [...] nos tráz um aspecto essencial à consciência do EGO [...] com Kronos penetramos na era do tempo e da autoconsciência" (p. 89). [grifo do autor]. Kairós, ao contrário, é o tempo com sentido de aproveitamento, é o momento certo.

No tratamento psicoterápico, a vivência é de Kairós, cada paciente tendo o seu tempo próprio e crescendo de acordo com suas possibilidades. 
A respeito do tratamento da neurose, Jung (1974/1993) ressalta que o paciente neurótico está doente no todo de sua personalidade, não havendo um foco isolado da doença, e que esta não contém apenas algo negativo, mas também inclui pontos positivos. Jung considera que na neurose há aspectos da personalidade que ainda não foram desenvolvidos e, que ao tentar "arrancar a neurose", o psicoterapeuta estará destruindo a possibilidade desse potencial de desenvolvimento se atualizar. Essa idéia pode ser sintetizada na afirmação de Jung (1974/1993) de que "Na neurose encontra-se nosso maior amigo ou inimigo" (par. 359), ao paciente cabendo aprender como suportar sua doença e descobrir o seu significado, pois é esta descoberta que propicia a cura.

Salman (2002), discorrendo sobre a importância da conversação entre ego e o resto da psique na análise junguiana, afirma que esse diálogo deve ser contínuo e é esperado que se altere com o decorrer do processo psicoterápico.

Mas a questão central permanece a mesma: manter uma tensão dinâmica e um relacionamento flexível entre o ego e o resto da psique. A análise junguiana não está preocupada em tornar consciente o inconsciente (o que é impossível na concepção de Jung), ou simplesmente analisar as dificuldades passadas (um possível impasse), embora estas duas coisas entrem em jogo. $O$ objetivo é um processo: encontrar um modo de se reconciliar com o inconsciente bem como de lidar com dificuldades futuras. Este processo consiste em manter um diálogo contínuo com o inconsciente que facilite a integração criativa da experiência psicológica. (Salman, 2002, p. 72) [grifo da autora]

Penna (2003) ao discutir as relações e os instrumentos que podem se interpor entre o eu-outro na psicoterapia, acrescenta que:

[...] a relação que se estabelece entre o sistema observante e o sistema observado vai além da relação sujeito-objeto (eu-outro). Entre os dois sistemas pode se interpor um instrumento (relato, teste psicológico, técnica expressiva), como equipamento técnico favorecedor e facilitador da observação do símbolo. A equação de ambos sistemas também se interpõe tanto na emissão da imagem a ser observada como na sua captação. O campo de observação psicológica é um campo simbólico que preenche de significados o processo de observação. (Penna, 2003, p. 172)

Essa autora ainda complementa: 
A observação é condicionada pela visão do observador. A equação psíquica do sistema observador inclui dois aspectos que se somam: a personalidade do observador, sua subjetividade e seu ponto de vista teórico na observação em curso. [...] $O$ processo de observação integra sujeito e objeto em sua totalidade consciente e inconsciente, podendo ser almejado apenas um equilíbrio entre subjetividade e objetividade, que oscila entre a objetividade possível e a subjetividade controlável. (Penna, 2003, p. 175)

Cabe aqui assinalarmos o papel da transferência e da contratransferência dentro do processo psicoterápico. Samuels, Shorter \& Plaut (1988) lembra que "A alquimia torna-se uma metáfora pertinente quando consideramos o relacionamento entre ANALISTA E PACIENTE. A ênfase de Jung sobre o processo dialético e a questão da transformação mútua pode ser ilustrada a partir da alquimia" (p. 23) [grifos do autor]. A transferência, para Jung, é considerada ao mesmo tempo um aspecto central da psicoterapia, algo inevitável e útil, e um limite. Pós-junguianos atenuaram essa ambivalência ao darem valor tanto à análise dos conteúdos simbólicos como ao processo transferencial.

Jung inovou ao apontar aspectos arquetípicos da transferência e ao desenvolver os componentes objetivos desta, tais como, a compensação, a empatia e o relacionamento. Especificamente em relação ao relacionamento é importante lembrar que, para Jung (1971/1981), este é uma condição para a individuação, o ego necessitando do outro sobre quem possa projetar seu material inconsciente, e com isso possibilitar a ligação consciente-inconsciente. A totalidade só pode ser alcançada através da alma, e a existência desta depende do outro lado que está contido na outra pessoa.

Tal como a neurose tem em si mesma um objetivo, sendo sua meta criar um novo equilíbrio para a personalidade ao tornar consciente o conteúdo inconsciente, a transferência é uma tentativa de o paciente autocurar-se e de o sistema psíquico buscar equilíbrio. Daí o fato de o processo de individuação ser considerado inerente à transferência.

Steinberg (1992), ao discutir o tema da transferência, aponta que, para Jung, a utilização de uma abordagem redutiva, durante a etapa da análise em que os conflitos infantis estão sendo resolvidos, é um caminho necessário e útil no processo de Individuação, e que o modo sintético de interpretação para lidar com temas arquetípicos torna-se mais viável quando cessa essa primeira abordagem - a redutiva. 
Jung foi um dos pioneiros a enfatizar a importância da análise didática e o valor terapêutico da contratransferência evocada pela transferência. Em sua obra (1971/1981), aponta o perigo de infecção e contágio psíquico durante a análise em função dos pontos frágeis do analista, assinalando a importância da personalidade do terapeuta como um dos fatores essenciais para a cura, sendo o sofrimento deste um fator curativo fundamental.

Os pós-junguianos ampliaram essa afirmação dizendo que o fator terapêutico essencial para que uma análise se desenvolva a contento é a reação do terapeuta na contratransferência. Segundo Pierri (2002), "o analista deve interpretar suas respostas subjetivas e fantasias e fazer uso delas para dar sentido ao material e às expectativas do analisando. A habilidade e competência do analista no uso desta contratransferência irá em grande parte determinar o sucesso ou fracasso da análise" (p. 159).

$\mathrm{Na}$ relação médico-paciente existem fatores irracionais que produzem transformações mútuas. [...] (quanto à exigência de todo terapeuta seja obrigatoriamente analisado) Ela significa simplesmente que o médico também "está em análise", tanto quanto o paciente. Ele é parte integrante do processo psíquico do tratamento, tanto quanto este último, razão por que também está exposto às influências transformadoras. (Jung, 1971/1981, p. 69) [grifos do autor].

Ainda a respeito do diálogo entre consciente e inconsciente, Maroni (1998) enfatiza que sonhos e fantasias ativas são o objeto desse diálogo em que o terapeuta atua como um hermeneuta, um intérprete, que ajuda na tradução dos conteúdos simbólicos que emergem.

Sobre a importância dos sonhos na Psicologia Analítica, Jung refere que

Tudo o que é consciência separa, mas no sonho entramos no mais profundo, mais geral, mais verdadeiro e mais eterno da pessoa que ainda está no lusco-fusco da noite a começar, quando ainda era o todo e o todo era nela, quando o eu se identificava com a simples natureza. É dessa profundeza que tudo une que nasce o sonho, por mais infantil, grotesco ou imoral que seja [...]. (Jung, 1974/1993, par. 304-305)

$\mathrm{Na}$ mesma obra, Jung relata que pedia para que os pacientes prestassem atenção aos seus sonhos, pois eles eram imparciais e eram produtos espontâneos 
do inconsciente. Nesse sentido, eles expressavam a própria subjetividade do sonhador e podiam indicar a atitude inadequada geradora do desequilíbrio. Em vários momentos de sua obra, Jung nos lembra que sempre sonhamos sobre nós e a partir de nós e que os sonhos têm a importante capacidade de oferecer um novo ponto de vista.

Ocupar-se com os sonhos é uma espécie de tomada de consciência de si. [...] O melhor é tratar um sonho como se fosse um objeto totalmente desconhecido: deve-se olhá-lo de todos os lados, tomá-lo nas mãos, levá-lo de cá para lá, despertar todo tipo de fantasias sobre ele, falar dele com outras pessoas. Os primitivos contavam sempre seus sonhos impressionantes e, quando possível, em reuniões públicas; [...] Tratado assim, o sonho sugere todo tipo de associações que nos levam mais próximos de seu significado. (Jung, 1974/1993, par. 318-320) [grifos do autor]

\subsubsection{A Imaginação Ativa}

Como mencionamos anteriormente, há diferentes formas de se estabelecer um diálogo com o inconsciente, e a Imaginação Ativa é uma forma particular entre elas que exige, ao ser utilizada, o máximo cuidado e respeito em função da natureza volátil do inconsciente.

Inicialmente faz-se necessário diferenciá-la da fantasia livre. Esta última se caracteriza por um afastamento da realidade, não levando a ações no plano da realidade concreta, enquanto na Imaginação Ativa há uma participação ativa do ego, este funcionando como o fio de ligação para que conteúdos do inconsciente coletivo se manifestem. A posição do ego neste sentido é de liderança, e, ao mesmo tempo, de equilíbrio entre a liberdade de manifestação dos conteúdos inconscientes e os interesses do consciente.

Na Imaginação Ativa, não existe nenhuma meta a ser atingida, a pessoa, conforme diz Von Franz (1999) "simplesmente começa com o que vem de dentro dela, com uma situação de sonho relativamente inconclusiva ou uma momentânea modificação do estado de espírito. Se surge um obstáculo, a pessoa que medita é livre para considerá-lo ou não como tal; é ela que resolve como deve reagir diante dele" (p. 179). 
Essa autora complementa afirmando que cabe ao próprio paciente explorar sozinho o que emerge e tomar a melhor decisão frente à situação, como o faria na vida externa, não cabendo ao psicoterapeuta intervir sugerindo ou indicando um caminho.

A expressão do material inconsciente por si só não propicia a ampliação da consciência, o que só pode ocorrer através da compreensão por analogia.

Descobri que, quando alguém tem dúvidas sobre a validade universal daquilo que o inconsciente produziu, a amplificação por analogia supera esse sentimento e que, por meio de tal procedimento, o indivíduo se torna mais capaz de entender e aceitar o mito e os mistérios de sua própria alma. Ele pode descobrir material analógico que o força a aceitar sua própria vinculação com a totalidade da raça humana e seus fundamentos intrínsecos. (Weaver, 1996, p. 46)

Pretat (1997) aponta para o valor da Imaginação Ativa lembrando que o próprio Jung salientava que o "envolvimento voluntário com uma fantasia pode parecer uma psicose, mas existe uma enorme diferença, pois em vez de sermos inundados por incontroláveis fantasias que emergem do inconsciente, um envolvimento voluntário com a imaginação ativa tem um objetivo" (p. 135).

Na medida em que conseguia traduzir as emoções em imagens, isto é, ao encontrar as imagens que se ocultavam nas emoções, eu readquiria a paz interior. Se tivesse permanecido no plano da emoção possivelmente eu teria sido dilacerado pelos conteúdos do inconsciente (o que seria uma psicose). Ou, talvez, se os tivesse reprimido, seria fatalmente vítima de uma neurose e os conteúdos do inconsciente destruir-me-iam do mesmo modo. Minha experiência ensinou-me o quanto é salutar, do ponto de vista terapêutico, tornar conscientes as imagens que residem por detrás das emoções. (Jung, 1961/1988, p. 158)

Von Franz (1999) divide o processo de Imaginação Ativa em quatro fases:

1) Esvaziamento da nossa consciência egóica e interrupção do fluxo do pensamento.

2) A imagem de fantasia proveniente do inconsciente flui para o campo da percepção interior, ela é acolhida e o paciente se fixa nela e passa a concentrar sua atenção nela.

3) A imagem de fantasia é expressa de alguma forma: pela escrita, pintura, escultura, linguagem corporal, música etc. 
4) A confrontação moral com o material inconsciente manifesto.

A aplicação no dia-a-dia do que foi aprendido com esse processo é um momento importante que pode revelar se a confrontação moral foi realmente completa ou não.

A mesma autora aponta para aspectos importantes da Imaginação Ativa: é uma forma de influenciar o inconsciente e seu efeito é mais poderoso que a interpretação correta de um sonho, pois permite que o paciente se organize e com isto se torne menos dependente do analista, ficando mais autônomo e mais responsável por si mesmo; possibilita "um extraordinário trabalho direto com afetos que podem fornecer uma saída para o impasse da supressão ou da ab-reação, das quais a primeira é pouco saudável e a segunda freqüentemente impossível externamente" (p. 172), e é um veículo poderoso para o processo de individuação.

Samuels, Shorter \& Plaut (1988) sintetiza o processo de Imaginação Ativa.

Jung usou o termo [Imaginação Ativa] em 1935 para descrever um processo de sonhar com olhos abertos [...]. De saída, o indivíduo concentra-se em um ponto específico, uma disposição, quadro ou evento específicos, em seguida permite que uma cadeia de FANTASIAS associadas se desenvolvam e gradativamente assumam um caráter dramático. Depois, as imagens ganham vida própria e desenvolvem-se de acordo com uma lógica própria. A dúvida consciente deve ser superada e conseqüentemente que haja permissão para que qualquer coisa incida na consciência. Psicologicamente, isso cria uma nova situação. Conteúdos anteriormente isolados tornam-se mais ou menos claros e articulados. Uma vez suscitado o sentimento, o EGO consciente é estimulado para reagir mais imediata e diretamente que no caso verificado com os SONHOS. (Samuels, Shorter \& Plaut, 1988, p. 99) [grifos dos autores]

Von Franz (1999) salienta que "a imaginação ativa confere expressão ao fator psíquico que Jung chamou de função transcendente. [...]. Por conseguinte, a imaginação ativa efetua algo semelhante a um amadurecimento da personalidade mais intenso e acelerado (em comparação apenas com a análise dos sonhos)" (pp. 166-167).

Pretat (1997), a partir da sua experiência psicoterápica com idosos, afirma que "a imaginação ativa nos anos de declínio pode nos fazer mergulhar mais profundamente na psique do que qualquer outra coisa que já tenhamos feito antes" (p. 137). 
Jung, a partir de seus estudos alquímicos, constatou que, ao vivenciar o processo evolutivo juntamente com o paciente, o próprio analista também se transformava, e que essa condição era básica para que a análise se desenvolvesse. A cura, portanto, na abordagem da Psicologia Analítica, significa tornar sadio um paciente através da transformação e do desenvolvimento dos recursos criativos da sua psique. Grande parte do trabalho analítico, segundo Salman (2002, p. 75), visa "diferenciar o pessoal do arquetípico, e ao mesmo tempo integrar, por meio da simbolização, a experiência pessoal e arquetípica” . [grifos da autora] Dessa forma, o movimento terapêutico se processa no sentido da busca da individuação: o paciente se torna aquilo que de fato ele é.

\subsubsection{O Uso dos Recursos Expressivos na Psicoterapia}

Há uma escassez muito grande de informação sobre o uso de desenhos no contexto psicoterápico, seja no atendimento individual ou grupal, de orientação junguiana.

Segundo Furth (2004), conteúdos psíquicos inconscientes importantes são transmitidos pelos desenhos dos pacientes e se estes são analisados podem favorecer insights terapêuticos de grande valor. Não se pode considerar nenhum ponto como definitivo sobre o que está acontecendo na psique do paciente, mas a análise do material verbal e de outros desenhos pode favorecer um diagnóstico ou prognóstico com mais confiança.

Jung enfatizou a importância dos símbolos, e uma das formas pelas quais os símbolos se expressam é por meio dos desenhos. Através deles aproximamo-nos do uso dos símbolos como agentes de cura. Esse agente faz parte, tanto somática quanto psicologicamente, do desenvolvimento do que Jung chama de processo de individuação.

A palavra, como outros sinais, na sua finitude e no seu caráter explicativo e analítico, tem tomado espaço demasiado na nossa cultura em detrimento da linguagem simbólica, que na sua infinitude e invisibilidade, ficou relegada aos conteúdos dogmáticos e fenômenos religiosos. Enquanto a palavra esgota-se em si mesma, assim como outros sinais culturalmente determinados, o símbolo, por ser polivalente, não ser explicável e sim exigir compreensão, 
contém o "divino" e o incomensurável. (Schwarz, 1999, p. 19) [grifo da autora]

Como já foi mencionado, as imagens provenientes do inconsciente coletivo são arquetípicas e se manifestam nos sonhos e nas fantasias, nos mitos e na religião. Segundo Furth (2004), "quando essas imagens surgem, somos 'tocados" de alguma forma, como se soubéssemos que elas pertencem a nós, que são verdadeiras e que trazem um sentido que não podemos explicar" (p. 31). [grifo do autor] No desenho, regiões profundas do inconsciente deslocam-se para a consciência e aí há a possibilidade de diálogo entre o consciente e o inconsciente.

Este mesmo autor assinala que nos desenhos podem emergir do inconsciente, tanto complexos positivos como negativos, e por meio do símbolo podemos chegar ao complexo com o qual o problema, causador do sofrimento psíquico, se mistura. Ao ativarmos o complexo, a energia ligada a ele é liberada e pode novamente fluir e ser trazida para a consciência, e essa redistribuição da energia psíquica é fundamental para o equilíbrio da psique.

Esse trabalho com os complexos, através dos recursos expressivos, pode gerar crescimento e desenvolvimento da psique individual, inclusive porque, diferentemente da linguagem oral, os desenhos não comportam a influência da racionalidade e, portanto, comunicam diretamente a situação psíquica do sujeito.

Furth (2004) lembra que ao fazermos contato com qualquer aspecto de um complexo, a sua estrutura geral é sempre afetada. Independentemente da parte do complexo que é "tocada", ele e a sua potência serão alterados. O que importa é que no desenho o complexo está entrelaçado com todos os seus componentes de uma forma altamente intrincada e, ao ativarmos um ponto, estamos mobilizando todo o resto.

Esse autor considera também que, na análise do material gráfico, devemos estar atentos para os pontos focais do desenho que podem revelar onde a energia está situada, se ela está fluindo ou bloqueada.

Ele lembra que o desenho, como os sonhos, não se encontram alinhados com a atitude ou a intenção consciente, são independentes e existem por si só. Jung se refere a esta condição como "a autonomia do inconsciente". Quando um conteúdo inconsciente coincide com o mundo consciente, dizemos que os dois mundos se complementam, o que difere da compensação. Nesta última predomina a oposição 
ao mundo consciente, o que gera um efeito equilibrador na psique. Como nos sonhos, é importante no desenho descobrirmos se a figura desenhada está compensando ou complementando a psique, posteriormente, é fundamental perceber o que a pessoa é capaz de aprender a partir dessa informação.

Furth (2004) retoma a teoria dobre a dinâmica da energia psíquica ao se referir à atuação compensatória ou complementar de um símbolo do inconsciente, frente a uma determinada situação do consciente. Um símbolo compensatório expressa a área negligenciada, tanto por meio de um sonho ou fantasia quanto de um desenho, na tentativa de trazê-la à atenção da consciência e promover uma mudança na atitude consciente. A área negligenciada sempre exige atenção de alguma forma. Desse modo, o símbolo possui uma influência curadora, esforçandose por alcançar um equilíbrio e uma totalidade.

Entre as características do símbolo, esse autor assinala que a linguagem simbólica refere-se a algo tão profundo e complexo que a consciência, com seus limites, não tem condições de captar o seu significado de uma só vez. O símbolo sempre carrega um elemento do desconhecido e inexplicável, daquilo que não é acessível às palavras e que, muitas vezes, possui uma qualidade numinosa. Jung (1961/1988) assinala que esta qualidade se refere àquilo que é "o inexprimível, tremendo, o 'totalmente outro', propriedades que possibilitam a experiência imediata do divino" (p. 357).

O próprio fato de o símbolo existir indica que, em algum nível, o indivíduo sabe ou sente o significado que ele contém. Nessa tensão entre saber e não saber, entre consciente e inconsciente, existe uma grande quantidade de energia psíquica.

Furth (2004) chama atenção para o fato de que a liberação da energia psíquica inconsciente através do símbolo tem um efeito transformador. A liberação de um quantum de energia possibilita que o indivíduo se relacione com seus conteúdos inconscientes e encontre meios de solucionar o problema.

Harding (citado por Furth, 2004), acrescenta

Parece que para um símbolo reconciliador ou redentor ser eficaz é necessário o cumprimento de quatro etapas. Primeiro, o indivíduo deve estar profundamente preocupado com a sua situação; segundo, ele deve ter feito tudo o que estava ao seu alcance para encontrar uma resolução consciente para o seu dilema; terceiro, o símbolo deve, ele próprio, expressar o processo vital do inconsciente, ativo nesse indivíduo em particular; e, por último, o 
indivíduo deve captar o significado do símbolo que lhe é apresentado, não apenas com o intelecto, mas também com o coração, devendo, então, deixar-se influenciar por seus ensinamentos. (Furth, 2004, p. 45)

Furth (2004) pontua que, diferentemente do artista, que está interessado na estética e na técnica, o paciente quando utiliza os recursos expressivos, além de estar motivado por uma necessidade interna de produzir, o que está diretamente relacionado à psique individual, manifesta nos seus desenhos conteúdos inconscientes significativos principalmente por sua tonalidade afetiva. $\mathrm{O}$ valor aí contido está justamente na sua própria expressão psíquica, na força dos elementos inconscientes ativados.

Esse mesmo autor afirma que qualquer desenho possui um efeito catártico e essa catarse permite que o símbolo mova a energia psíquica interna e dê início ao processo de cura.

Quando as figuras emergem do inconsciente, diz Furth, elas carregam uma enorme quantidade de informação psíquica, e por meio da figura podemos acompanhar a jornada da psique e saber onde ela se encontra no momento em que o desenho foi feito.

Jung, em vários momentos na sua obra, remete à importância da expressão gráfica no processo psicoterápico, como meio de ativar o sentido que a fantasia possa conter. Diz ele (1971/1981) "[...] Mas é porque a sua fantasia não lhe parece totalmente desprovida de sentido que, ao ativá-la, o efeito se acentua" (p. 46).

Jung, entre 1918-1919, pintou suas primeiras mandalas e começou a compreender o significado das mesmas.

Meus desenhos de mandalas eram criptogramas que me eram diariamente comunicados acerca do estado de meu "Si mesmo". Eu podia ver como meu "Si mesmo", isto é, minha totalidade, estava em ação. (Jung, 1961/1988, p. 173) [grifos do autor]

Em sua obra A prática da psicoterapia, Jung (1971/1981), ao relatar como trabalhava com os sonhos dos pacientes, revela que muitas vezes os estimulava a pintar o que eles viam no sonho ou na fantasia, enfatizando que o importante não era o valor artístico, mas "o esforço de traduzir o indizível em formas visíveis" (p. 46), isto é, que o sentido da vida individual pudesse se manifestar. Na mesma obra, Jung afirma que o paciente, a partir desse método, pode, não só falar dos assuntos da 
sua vida, mas executá-los e assim tornar-se independente em sua criatividade. "[...] o que pinta são fantasias ativas - aquilo que está mobilizado dentro de si” (p. 47).

Nise da Silveira (1981), em sua obra Imagens do inconsciente, relata: "Por meio desse método (expressão do mundo interno através de qualquer tipo de arte) onde se conjugam imagem e ação, Jung descobriu o desdobramento de um processo inconsciente, o da individuação, que é o próprio eixo de sua psicologia" ( $p$. 102).

Païn e Jarreau (1996) apontam que os diferentes trabalhos: a lápis, em aquarela, a água, a óleo, a argila, conduzem os participantes a investimentos diferentes e os mobilizam de formas diversas.

Um outro autor que nos traz uma reflexão interessante sobre a importância das imagens psíquicas é Sant Anna (2005). Diz ele que "Para a Psicologia Analítica, a imagem não é apenas uma representação visual, resultado da percepção sensorial, da atividade mnemônica ou da transferência da energia psíquica, mas é a linguagem básica da psique, criativa e autogeradora em si mesma" (p. 19). Esse autor acrescenta que a imagem é uma idéia e uma emoção ao mesmo tempo, e essa condição multifacetada decorre do fato de ela conter um componente ideativo associado a uma constelação emocional.

[...] a imagem é a consciência em seu estado puro; ocorre toda vez que a experiência do indivíduo encontra expressão na psique, seja pela via da percepção - visual, tátil, olfativa, gustativa ou auditiva -, seja pela intuição, da emoção, da linguagem ou do sentido. Nesses casos forma-se uma gestalt, que, embora inicialmente não possa ser apreendida racionalmente, pode ser reconhecida pela consciência, o que the possibilita a captação do experienciado. (Sant'Anna, 2005, p. 20)

A ativação da imagem acarreta um movimento da consciência no sentido de buscar compreensão e o sentido nela contido. Sant'Anna complementa afirmando que é "por intermédio da imagem que a consciência pode se auto-observar em sua eterna constituição, em seu fluxo criativo. Sua expressão é fluida e dinâmica, uma vez que reflete o processo psíquico em seu desenvolvimento contínuo [...]" (p. 21). Por ser a imagem a matéria-prima da psique, qualquer abordagem racional tem um efeito redutor e desvitalizador, daí a necessidade de adoção de uma abordagem compreensiva, não-interpretativa, que capte sua natureza fluida e dinâmica. 
O mesmo autor aponta que atualmente todas as linhas psicoterápicas, em sua prática clínica, incluem, às vezes de formas diferentes, o trabalho com estas produções, seja através do desenho, da pintura, da análise dos sonhos ou visualizações, visando ao diálogo entre consciente e inconsciente.

Como Furth (2004), Sant'Anna reconhece o valor adaptativo, criativo e terapêutico da produção de imagens psíquicas, e propõe, no trabalho com as imagens, o estabelecimento de uma conexão emocional e vivencial com elas, como um meio bastante eficaz de aproximação da realidade psíquica do paciente.

Samuels (1989), ao apresentar o eixo de desenvolvimento da Psicologia Analítica, aponta que as diferentes escolas trabalham com a imagem de formas diversas em função de aspectos teórico-práticos peculiares a cada uma delas.

Sant'Anna (2005), retomando as propostas de Hillman, assinala que o processo de trabalho com a imagem acontece a partir do desenvolvimento de uma "consciência de alma", isto é, de uma consciência metafórica. Nessa abordagem imagética, as imagens são consideradas, não como símbolos que devem ser interpretados, mas como fenômenos psíquicos, formas de expressão da psique repletas de emoção e significado e que só podem ser vivenciadas e experimentadas emocionalmente.

Sant'Anna ainda destaca a força da imagem como elemento mediador, mobilizador e potencializador dos processos psíquicos, alertando para o perigo de uma teoria psicológica sobre as imagens psíquicas favorecer o desenvolvimento de conceitos pautados na racionalidade e se distanciar da sua natureza emocional.

A abordagem imagética proposta pela escola arquetípica favorece, portanto, a potencialização do movimento auto-regulador da psique. Cabe aqui ressaltar que esse tipo de abordagem da imagem representa desafios para a atuação do terapeuta, na medida em que vai ser a fluência imagética deste e suas habilidades para atuar, também de forma fluida e intuitiva, que vão favorecer, como diz Sant'Anna, a criação de um setting analítico fluido em que predomina a condição do paciente dialogar com suas imagens internas e tê-las como referenciais de seu processo.

É preciso considerar, no trabalho com imagens, que o que se manifesta está diretamente ligado à importância e ao enfoque que o terapeuta dá a ela. Se o terapeuta não vê nada na imagem, não pode levar o paciente a fazê-lo; se ele busca encaixar as imagens 
nos modelos de desenvolvimento imagético que conhece, vai reduzilas a esses modelos; mas se ele enxerga na imagem um processo vivo em andamento, vai potencializar esse processo. (Sant'Anna, 2005, p. 34)

Esse autor afirma ainda que em psicoterapia de orientação junguiana há uma diversidade de técnicas utilizadas para se trabalhar com imagens, como: a imaginação ativa, o sonho, inclusive os sonhos em grupos, os recursos expressivos - como o desenho, a pintura, o jogo de areia - os mitos, os contos de fadas, o trabalho corporal etc.

Em relação ao trabalho com sonhos em grupo, Sant'Anna refere que "é um trabalho predominantemente vivencial, que busca a aproximação direta com o sonho, mediante o qual o grupo funciona como mediador e amplificador da imagem" (p. 35). Como condição para que este trabalho aconteça de forma satisfatória, o autor considera que, além da anotação dos sonhos, deve haver um contexto grupal seguro que favoreça intimidade, afetividade e sigilo entre os membros do grupo.

Em relação ao uso do desenho, Sant'Anna afirma que através desse recurso "é possível objetivar a imagem e dialogar com ela, bem como despontencializá-la em momentos de intensa atividade psíquica" (p. 35). O trabalho bem-sucedido com esse tipo de recurso depende da expressão gráfica por parte do paciente e do estabelecimento de uma ponte entre consciência e inconsciente.

O uso dessas técnicas, no trabalho com imagens, aponta Sant'Anna, "é sobretudo uma construção dialética, realizada no confronto direto com a imagem" ( $p$. 36), e, nesse sentido, a técnica sozinha não garante um trabalho satisfatório e eficaz se a relação terapêutica não for satisfatória e se a personalidade do paciente não estiver bem estruturada.

Ainda a respeito dos recursos que podem ser utilizados no trabalho com as imagens, Sant'Anna indica a amplificação, recurso este que " torna presente e enriquece a imagem por meio do processo associativo" (p. 37).

A amplificação, no contexto grupal, ocorre quando a imagem é enriquecida pelos diversos enfoques que os diferentes elementos do grupo atribuem a uma imagem. Seja por meio de perguntas que visam recuperar a imagem e explorar as associações que o sujeito faz com elas, seja por meio da troca de impressões ou sobreposição de imagens, oportunidade em que se amplifica a imagem inicial até que se obtenha uma resposta pessoal em relação a ela. (Sant'Anna, 2005, p. 38) 


\section{CAPÍTULO III}

\section{O PROCESSO DE ENVELHECIMENTO E O SENTIDO DA VIDA}

\section{Vida}

\subsection{A visão de Jung: $O$ Envelhecimento como Tempo de Revisão de}

Coube à Psicologia Analítica a proposta de uma mudança profunda na visão dos mecanismos inerentes ao envelhecimento, como a introversão, os conflitos existenciais e a depressão, considerando-os como molas propulsoras ao crescimento psíquico que deveriam ser "trabalhados", e que constituem elementos necessários a novas maneiras de ser.

Jung foi um dos pioneiros da teoria de curso de vida, introduziu a perspectiva da vida como um todo, seu modelo contemplava os mundos interno e externo, a importância do contexto cultural, a questão da religiosidade e o aspecto filogenético. $\mathrm{Na}$ verdade, seu modelo procurava levar em conta o homem por inteiro.

Em relação especificamente à velhice, Jung afirmava que os últimos anos são preciosos para se fazer uma revisão da vida e para reparar erros, e, portanto, a vivência dessa etapa era fundamental para o desenvolvimento pleno da personalidade.

\subsubsection{O Desenvolvimento Humano e as Etapas da Vida}

Atualmente, entre os diversos autores da psicologia do desenvolvimento, podemos citar Erik Erikson (1998) como um estudioso cuja teoria mais se aproximou 
dos conceitos de desenvolvimento humano de Jung. Erikson descreveu oito estágios básicos, sendo os primeiros seis aplicados à primeira infância até a vida adulta e os dois restantes `a velhice. O modelo que utiliza para descrever os estágios e a forma como estão interligados é passível de ser ampliado e essa ampliação o aproxima muito da forma como Jung percebe o desenvolvimento da pessoa.

Samuels (1989) aponta que há três formas diferentes, entre os autores pósjunguianos, de tratar o desenvolvimento humano. A Escola Clássica se refere a um desenvolvimento em espiral, a Escola Arquetípica parte da noção de que o desenvolvimento se dá de forma circular e a Escola de Desenvolvimento focaliza os estágios e, portanto, encara o desenvolvimento humano de forma linear.

A respeito da história do desenvolvimento psicológico de uma pessoa, destacam-se os trabalhos de Neumann (1995) que apontam para o fato de que um ego saudável está alicerçado em sentimentos básicos de segurança, um legado da mãe, e da relação primal. Esse sentimento de confiança funciona como uma base para o desenvolvimento de todas as demais relações humanas durante a vida e como fonte de energia para lidar com todo tipo de conflito. A influência do pai é no sentido de fortalecer esse sentimento primário, validá-lo e favorecer gradativamente, na vida futura, o sentimento de ser capaz e de possuir instrumental para construir seus próprios caminhos e superar obstáculos a partir da sua própria força.

Segundo Salman (2002), a visão de Jung sobre o desenvolvimento psicológico contempla a articulação da dimensão arquetípica da psique e a experiência pessoal dela, a importância do arquétipo feminino para ambos os sexos, os aspectos masculinos (animus) e femininos (anima) da psique presentes na mulher e no homem respectivamente, ambos sendo igualmente importantes e o postulado de que o desenvolvimento psicológico se dá durante toda a vida adulta.

Stevens (1993), analista junguiano londrino, assinala que, para Jung, toda a vida é um ato de equilíbrio entre o pessoal e o coletivo e isto decorre do fato de todas as estruturas arquetípicas serem, ao mesmo tempo, universais em suas formas essenciais e singulares, e únicas em suas manifestações individuais.

A probabilidade é que o si mesmo com o qual nascemos já esteja estruturado, sob muitos aspectos importantes, como um si mesmo masculino ou feminino, e isso fornece o substrato sobre o qual os estereótipos masculino e feminino da cultura dentro da qual nascemos começam a realizar a sua tarefa. [...] o ser humano, ao nascer, não é nenhuma tabula rasa que se submete passivamente 
ao registro das lições da vida, mas um participante ativo no processo de desenvolvimento. Embora aceitasse facilmente a idéia de que os fatores ambientais exercem enorme influência sobre o desenvolvimento psicológico do indivíduo, mesmo assim, Jung insistia em afirmar que o que esses fatores influenciam são as predisposições e as "aptidões subjetivas" com as quais todas as crianças já nascem. (Stevens, 1993, pp. 87-88) [grifos do autor]

A visão do desenvolvimento humano, adotada por Jung, parte então do pressuposto de que as etapas da vida são arquetipicamente determinadas, e que desde o nascimento o indivíduo, nas diferentes fases, é levado a buscar a realização mais completa possível do si mesmo. O meio ambiente pode favorecer ou não esta realização, havendo uma frustração do intento arquetípico quando o meio não supre as necessidades para que o desenvolvimento do indivíduo ocorra de forma satisfatória.

Jung, segundo Stevens (1993), propõe a existência de um projeto arquetípico para a vida no qual a "herança arquetípica com a qual cada um de nós nasceu pressupõe o ciclo de vida natural da humanidade, [...] e o projeto de vida reside na realização progressiva deste programa arquetípico que está inserido de forma tão marcante no si mesmo" (p. 94).

Uma vez que nenhum indivíduo jamais consegue manifestar todas
as qualidades que estão em estado de dormência na natureza
humana, o si mesmo encoberto está sempre iminente. Todos
aqueles aspectos do si mesmo que ainda estão para ser vividos
oferecem uma dinâmica prospectiva que proporciona um objetivo e
um sentido à existência humana. [...] do ponto de vista da terapia
junguiana o que conta não é tanto o que nós somos, ou o que
fomos, mas o que estamos em processo de ser no futuro. Esta é a
própria essência do processo de individuação. (Stevens, 1993, pp.
94-95)

Wagner (1989) lembra que o indivíduo é também agente do seu processo evolutivo único, e, do nascimento até sua morte, ele possui, como característica fundamental, a capacidade de ser transformado e de transformar. O desenvolvimento psíquico inicia-se, portanto, num estado de totalidade indiferenciada e evolui em direção a uma diferenciação crescente, cada vez mais equilibrada e unificada. 


\subsubsection{A Primeira Metade da Vida}

Em relação às mudanças que se operam durante os diferentes ciclos da vida, Jung enfatizou que, na primeira fase, o indivíduo, numa jornada empreendida basicamente pelo ego, tem de enfrentar problemas relacionados à sua posição no mundo, tendo de procriar, manter sua prole e posicionar-se socialmente, enquanto que, na segunda metade da vida, agora guiado pelo si mesmo, seu objetivo é cultural.

Neumann (1991), na sua obra História da origem da consciência se refere à importância do eixo ego-si mesmo no desenvolvimento do indivíduo.

Edinger (1989) afirma que o ego está inicialmente contido no si mesmo, como elemento potencial, e, conforme o desenvolvimento se processa, ele vai gradativamente se diferenciando. "A linha que serve à conexão entre o centro do ego e o centro do Si mesmo representa o eixo ego-Si mesmo - o vínculo vital que faz a ligação entre o ego e o Si mesmo e que assegura a integridade do ego" (p. 25).

Esse mesmo autor esclarece que "os diagramas servem ao propósito de ilustrar a tese segundo a qual o desenvolvimento psicológico se caracteriza pela existência de dois processos simultâneos: de um lado, a progressiva separação entre o ego e o Si mesmo; de outro, o aparecimento cada vez mais claro, na consciência, do eixo ego-Si mesmo" (p. 26).

De acordo com Jung (1971/1984), o desenvolvimento psíquico se processa a partir de uma forma inicial de consciência baseada na percepção de algumas conexões entre conteúdos diretamente ligados à criança formando "ilhas de consciência" (par. 755), em que ainda não há problemas. O ego vai gradativamente enfrentando o inconsciente, vai se fortalecendo, se estruturando e ampliando os limites da consciência. As mudanças corporais da adolescência, somadas às exigências do mundo externo ou mesmo do mundo interno, acarretam uma limitação interior e originam um estado de dualidade e, portanto, uma situação-problema que exige do adolescente uma atitude de enfrentamento e, conseqüentemente, maior ampliação da consciência. Nessa fase, a maior parte dos problemas origina-se do apego excessivo ao nível de consciência infantil, predominando uma persistência no 
estágio anterior e uma resistência para abrir-se para a vida e assumir os riscos que esta ampliação de horizontes possa conter.

Para Jung, o enfrentamento dos problemas possibilita a ampliação da consciência e o desligamento da nossa infantilidade inconsciente. A busca de uma vida segura, tranqüila e de certezas, bem como a dúvida e o medo, muitas vezes impedem a ampliação da consciência, nos mantendo inconscientes e identificados com a natureza. Como refere Jung (1971/1984), "Sem consciência, não existem problemas" (par. 754).

Os grandes problemas da vida nunca são resolvidos de maneira definitiva e total. E mesmo que aparentemente o tenham sido, tal fato acarreta sempre uma perda. Parece-me que a significação e a finalidade de um problema não estão na sua solução, mas no fato de trabalharmos incessantemente sobre ele. (Jung, 1971/1984, par. 771)

Durante o período da juventude, a afirmação da nossa atitude pessoal e da nossa posição social vai, portanto, reger o nosso processo adaptativo frente às exigências da realidade, e com isto aspectos importantes que poderiam ser também vividos são deixados de lado, o que representa um prejuízo para a totalidade da personalidade.

\subsubsection{A Metanóia - Tempo de Revisão de Vida}

$\mathrm{Na}$ sua autobiografia Jung (1961/1988) relatou visões e sonhos que o atormentaram durante a meia-idade e entre os sessenta e setenta anos e que sinalizavam tanto profundas mudanças internas, como externas relacionadas à I Guerra Mundial e à expansão do movimento nazista na Europa. Esse momento de crise, permeado com sentimentos de desorientação e desamparo, gerou uma grande mudança de atitude consciente e, como é característica do processo de individuação, transformações profundas aconteceram. 
nessa época da minha vida. Quando jovem pretendia contribuir com algo de válido no domínio da ciência à qual me devotava. Mas encontrei esta corrente de lava e a paixão nascida de seu fogo transformou e coordenou minha vida. Tal corrente de lava foi a matéria-prima que se impôs e minha obra é um esforço, mais ou menos decidido, de incluir essa matéria ardente na concepção do mundo do meu tempo. (Jung, 1961/1988, p. 176)

Entre 35 e 40 anos, a fase da metanóia, mudanças importantes que se iniciaram no inconsciente se manifestam na forma de uma revisão de vida em que alguns interesses antigos podem ser substituídos por novos, traços e convicções podem reaparecer ou, ao contrário, podem se enrijecer. Nessa fase, observamos uma inversão dos valores que direcionaram a primeira etapa da vida, e a sensação é de uma morte egóica e perda das referências da consciência. Ao ego é exigido que volte sua atenção a aspectos antes negligenciados ou não desenvolvidos e tal mudança acarreta a construção de um novo centro da personalidade, entre o ego e o self.

Na segunda metade da vida a regulação psíquica pode se dar pelo diálogo mais fluente entre consciência e inconsciente, conseguido através da vivência criativa do sacrifício do ego, que costuma ser simbolizado como uma morte e posterior renascimento. (Freitas, 1992, p. 118)

Maroni (1998) afirma que "a metanóia é, em si mesma, um meio natural de curar o nosso espantoso estado de alienação chamado de normalidade" (p. 126).

A forma como a meia-idade é vivida sinaliza o modo como o envelhecimento será vivido e se há condições de o processo de individuação se desenvolver. Freitas (1992) assinala que há mecanismos desviantes na vivência da metanóia e um deles é a "idade do lobo", caracterizado pela busca, por parte dos homens quarentões, de parceiras muito jovens, como meio de negar o seu envelhecimento e evitar as transformações inerentes a essa fase. O medo da vida leva o homem a querer permanecer numa etapa anterior, portanto, um processo neurótico, que constitui um desvio perigoso no processo de individuação.

Ao se referir às dificuldades sentidas nessa fase de transição, Jung as considera como profundas e altamente significativas e as compara com o curso diário do sol. 
Suponhamos um sol dotado de sentimentos humanos e de uma consciência humana relativa ao momento presente. De manhã, o Sol se eleva do mar noturno do inconsciente e olha para a vastidão do mundo colorido que se torna tanto mais amplo, quanto mais alto ele ascende no firmamento. O Sol descobrirá sua significação nessa extensão cada vez maior de ser campo de ação produzida pela ascensão e se dará conta de que seu objetivo supremo está em alcançar a maior altura possível e, conseqüentemente, a mais ampla disseminação possível de suas bênçãos sobre a terra. Apoiado nesta convicção, ele se encaminha para o zênite imprevisto imprevisto, porque sua existência individual e única é incapaz de prever o seu ponto culminante. Precisamente ao meio-dia, o Sol começa a declinar e este declínio significa uma inversão de todos os valores e ideais cultivados durante a manhã. O Sol torna-se, então, contraditório consigo mesmo. É como se recolhesse dentro de si mesmo seus próprios raios, em vez de emiti-los. A luz e o calor diminuem e por fim se extinguem. (Jung, 1971/1984, par. 778)

\subsubsection{Fase de Transição entre a Meia-Idade e a Velhice}

Pretát (1997) chama atenção também para uma outra fase importante que se situa entre a meia-idade e a velhice, em torno dos 50 a 60 anos, em que mudanças corporais e a acuidade sensorial e mental sofrem progressivo declínio. Nessa fase de transição, não estamos na meia-idade, e tampouco somos velhos, vivenciando em alguns momentos o vigor da juventude, e em outros os limites da velhice. Tais alterações podem acarretar sentimentos depressivos e sensação de perda da identidade, mas não há dúvida, conforme afirma Pretat, que "o corpo que envelhece também pode ser a fonte da criatividade e de uma nova energia vital que espera para ser liberada" (p. 14), e que as experiências sentidas como desorientadoras estão ativando transformações profundas na nossa consciência e abrindo possibilidades de crescimento.

Atualmente nossa cultura, de modo geral, tem poucos rituais de passagem para marcar os diversos pontos de transição, e isto é mais evidente no que se refere ao início das idades mais avançadas, mas mesmo assim o próprio desenvolvimento psicológico exige que esses rituais aconteçam guiados, nessa fase, pelo si mesmo. Tais rituais podem se manifestar de formas diversas: a mudança na rotina diária, o desenvolvimento de uma atividade nova, uma maior atenção em relação aos cuidados para com o nosso próprio corpo etc. 
Pretat (1997) assinala que muitas vezes uma crise nessa fase de transição se manifesta através do nosso corpo exigindo uma atenção especial, e mudanças corporais exigem que aumentemos nossa atenção à psique. "Uma das tarefas necessárias à individuação parece ser nos sentirmos à vontade com nosso ser físico. Às vezes isso assume a forma de uma doença grave” (pp. 38-39).

Nessa fase, o rosto e o corpo jovem sofrem mudanças mais acentuadas, as antigas máscaras da persona não são mais adequadas. Não apenas nossa percepção consciente e rotineira de nós mesmos, construída no decorrer da nossa vida, muda, mas nossa psique e nosso corpo são atingidos de forma irreversível e a vida muda de forma inexorável.

As diferentes personas que sempre foram utilizadas até essa etapa, tanto pelo homem como para a mulher, já não são satisfatórias para essa importante jornada interior iniciada na meia-idade. As dores, as doenças, bem como desejos sexuais que se manifestam de forma diferente, exigindo mais tempo, dedicação e também criatividade, contêm um significado simbólico que deve ser compreendido e é essa compreensão que pode gerar transformação e crescimento.

$\mathrm{Na}$ nossa cultura, que valoriza uma persona juvenil, os esforços para manter "eternamente" uma máscara de jovialidade podem, conforme Pretat (1997), "nos salvar da inflação de nos identificarmos com o arquétipo da velha ou do velho sábio, mas nos privam do acesso à sabedoria, criatividade e poder do envelhecimento natural" (p. 60).

Apesar dos inconvenientes do envelhecimento, o período liminartardio (a transição entre a meia-idade e a velhice) pode introduzir uma nova sensação de liberdade e individualidade. [...] As pessoas mais velhas podem improvisar mais, pois já não sentem a necessidade de venerar padrões familiares antigos e freqüentemente disfuncionais. [...] Elas podem se tornar mais corajosas e afirmar sua diversidade, sentir-se mais fiéis ao seu verdadeiro ser e preocupar-se menos em agradar aos outros. Elas ousam até ser extravagantes, adotar personas que se ajustam ao seu gosto pessoal e não nos padrões coletivos. (Pretat, 1997, pp. 30-31) [grifo da autora]

Essa autora afirma que é difícil enfrentar a necessidade de mudança, pois nosso temor frente ao novo tem o sabor de morte, e aponta que é necessário alterar a nossa antiga maneira de estar no mundo para abrirmos caminho para o novo. Esse posicionamento implica que precisamos enfrentar a realidade concreta e que 
só essa vivência, mesmo que dolorosa, é que possibilita a transformação necessária para a totalidade.

A perda da antiga persona nesse período de transição muitas vezes resulta num sentimento de invisibilidade, isto é, um sentimento de não ser vista ou reconhecida que aumenta ainda mais o temor de ter perdido a antiga identidade e de não ter uma outra. Esse temor, característico de qualquer iniciação e que está relacionado ao movimento da energia psíquica em direção ao inconsciente, se for muito acentuado pode dificultar o processo de transformação.

É de esperar que, especialmente quando atravessamos nossos anos de declínio, também possamos alcançar um lugar onde vivenciemos a vitória nas nossas derrota. Aceitar a nós mesmos e a nossa vida é uma lição que todos gostaríamos de aprender. Tanto essa lição quanto o desenvolvimento de um ego que suporte a verdade e não se imiscua no destino parecem ser metas que todos procuramos alcançar enquanto transpomos a passagem de transição do envelhecimento. (Pretat, 1997, p. 57)

\subsubsection{A Velhice}

O ser humano não chegaria aos setenta ou oitenta anos, se esta longevidade não tivesse um significado para a sua espécie. Por isso, a tarde da vida humana deve ter também um significado e uma finalidade próprios, e não pode ser apenas um lastimoso apêndice da manhã da vida. (Jung, 1971/1984, par. 787)

Pretat (1997) assinala que o trabalho de individuação da velhice é complexo e altamente individual, visando em sua essência à busca de partes da nossa personalidade que foram abandonadas durante a nossa vida. Daí que ao ego nessa fase é exigido um trabalho duplo: um movimento regressivo em direção a níveis profundos do inconsciente em busca dessas partes, e, ao mesmo tempo, uma atenção ao mundo externo necessária para preservar o contato com a realidade. Essa mesma autora complementa dizendo que "a experiência do descomprometimento (em relação aos valores do mundo externo) e da introversão é vital para a individuação" (p. 95).

Ao tentarmos permitir a dissolução dos nossos mais estimados padrões de existência, seguir aquilo que nos conduz às nossas 
profundezas, lutamos com as energias de luz e sombra tanto do nosso corpo quanto da nossa psique. As escolhas são nossas, mas as jornadas que podemos empreender poderão nos levar além de qualquer coisa que nossa mente racional possa esperar. Elas podem nos levar ao medo e aos sentimentos de desespero. Podemos achar que estamos enlouquecendo e que não somos mais capazes de usar o corpo. Podemos ficar esquecidos e desligados. Podemos perder a noção de quem éramos antes. Mas também podemos conquistar um tesouro, uma vida mais fértil. (Pretat, 1997, p. 138)

Nesse enfrentamento nos deparamos tanto com nossos medos mais profundos como com nossos recursos criativos. Deparamo-nos também com a realidade do nosso corpo mortal. É esse contato com nossas dificuldades e essa descida ao nosso mundo subterrâneo que possibilitam que novas potencialidades se manifestem.

Nos mitos é que encontramos a compreensão dos aspectos mais profundos da natureza humana, e tanto estes como as lendas sempre revelam que todo tipo de transformação é possível. Na velhice essas transformações podem ocorrer no sentido de aprendermos mais a respeito do nosso corpo e de suas limitações e de respeitá-las, do nosso papel na família e na comunidade numa dimensão diferente das fases anteriores. Segundo Pretat (1997), "Alcançamos um conhecimento profundo dos ciclos da mudança e do papel que neles representamos. A verdadeira metanóia é na verdade uma acumulação quase imperceptível de mudanças cotidianas" (p. 138).

Pretat (1997) salienta ainda a importância, durante 0 processo de envelhecimento, da vivência do arquétipo da velha sábia, dizendo que essa experiência pode constelar nosso curador interno e facilitar a aceitação das exigências arquetípicas do nosso envelhecimento. "A velha sábia encarna as novas possibilidades da juventude, a produtividade da meia-idade, e tanto a privação quanto o sábio carinho da velhice" (p. 141). Ela possui qualidades sombrias, mas também o segredo da regeneração e a expressão criativa.

Vivemos numa época em que os mitos são esquecidos, mas Pretat aponta que a história da deusa Deméter (Anexo B), figura que personifica a velha sábia tanto em seus aspectos sombrios como luminosos, pode amplificar o caminho do envelhecimento e as dificuldades inerentes a este.

À medida que envelhecemos, tal como Deméter, sentimos a dor das diferentes perdas (aposentadoria, a saída dos filhos de casa, a morte dos amigos e 
parentes), nos angustiamos, não temos esperança de recuperar o que foi perdido, nos sentimos áridos, sem criatividade e sem rumo.

A necessária descida ao mundo subterrâneo e a abertura para que nossa energia seja redirecionada e se desenvolva acarretam um novo tipo de relacionamento entre o ego e o si mesmo, uma ampliação da consciência que nos fortalece para que novas possibilidades surjam e possamos adotar atitudes visando a um maior equilíbrio. A qualquer momento da nossa jornada podemos sentir a necessidade de buscar pela nossa Perséfone, procurar pela criança interior que ficou perdida durante nosso trajeto pela vida, e é justamente essa recuperação que pode nos transformar e nos libertar. Conforme Jung (1971/1984), é a partir dessa experiência que podemos consolidar nosso próprio destino.

Segundo Jung (1971/1984), o declínio característico da velhice pode causar sofrimento quando o idoso mantém valores infantilizados ou adolescentes num período em que deveria estar voltado para sustentar a cultura e assim atender ao chamado para a individuação. Quando, nessa fase, não conseguimos desenvolver uma nova atitude ficamos aprisionados no lado sombrio e regressivo do envelhecimento, predominando preocupações excessivas, e muitas vezes desnecessárias, com a saúde física, sentimentos de desvitalização e bloqueio dos recursos criativos e imaginativos. A interrupção do fluxo energético gera um sentimento de vazio interior insuportável que, muitas vezes, prejudica todas as áreas vitais.

Embora algumas pessoas tendam a identificar o idoso à criança, no sentido de ambos necessitarem de cuidados e representarem, na fala de Jung (1971/1984), "uma espécie de problema para os outros" (par. 795), na verdade, a infância e a velhice diferem na medida em que na primeira fase há um desenvolvimento a partir do inconsciente, enquanto na segunda há um mergulho progressivo nele.

A pessoa que se aproxima da velhice com sentimentos de frustração e aspirações não realizadas tende a manter seus olhos fixados no passado e isso é fatal num momento em que deveria ter uma perspectiva e um objetivo fixados no futuro.

Com efeito, tenho observado que uma vida orientada para um objetivo em geral é melhor, mais rica e mais saudável do que uma vida sem objetivo, e que é melhor seguir em frente acompanhando o curso do tempo, do que marchar para trás e contra o tempo. [...] o 
velho que for incapaz de se separar da vida é tão fraco e tão doentio quanto o jovem que não é capaz de construí-la. [...] seria aconselhável que só pudéssemos pensar na morte como uma transição, como parte de um processo vital cuja extensão e duração escapam inteiramente ao nosso conhecimento. (Jung,1971/1984, par. 789-792)

Jung ressalta, então, que, mesmo que não compreendamos a idéia da continuação da vida, faz parte da natureza humana a necessidade de aceitar as imagens primordiais relacionadas à idéia de imortalidade.

Aos 69 anos, Jung fraturou o pé e teve um enfarte cardíaco. Durante o período em que ficou inconsciente teve delírios e várias visões que o tocaram profundamente. Quando esses estados visionários cessaram, Jung (1961/1988) ficou com a impressão de que “'a vida' é este fragmento da existência, que se desenrola num sistema universal de três dimensões com essa finalidade específica" (p. 257), e ficou claro para ele que "Tudo o que ocorre no tempo concentrava-se numa totalidade objetiva. Nada estava cindido no tempo e nem podia ser medido por conceitos temporais [...]. Um todo indescritível no qual estamos mergulhados e que, no entanto, podemos perceber com plena objetividade" (p. 258).

Após os 70 anos, Jung concebeu suas principais obras, ousando na sua forma de se expressar e respeitando o fluxo dos seus pensamentos. Em sua autobiografia, afirma que após a doença teve a exata compreensão da importância de aceitar-se tal como era e de aceitar o destino e suas intenções. A aceitação dos pensamentos espontâneos como parte da realidade, sem a limitação imposta pelos julgamentos subjetivos, também passou a ser considerada um ponto importante.

Jung sempre buscou ampliar o conhecimento que tinha a respeito de si mesmo e dos outros, mas, mesmo assim, no final da sua vida, confessou ter dúvidas a respeito da sua própria vida e do valor desta. Sentimentos de insegurança a respeito de si mesmo coexistiam com sentimentos de encantamento por se sentir ligado a todas as coisas e criaturas do mundo.

Estou espantado, decepcionado, satisfeito comigo mesmo. Sinto-me triste, acabrunhado, entusiasta. Sou tudo isso e não posso chegar a uma soma, a um resultado final. É para mim impossível constatar um valor ou um não valor definitivos; não posso julgar a vida ou a mim mesmo. Não estou certo de nada. Não tenho mesmo nenhuma convicção definitiva - a respeito do que quer que seja. Sei apenas que nasci e que existo; experimento o sentimento de ser levado pelas coisas. Existo à base de algo que não conheço. Apesar de 
toda incerteza, sinto a solidez do que existe e a continuidade do meu ser, como sou [...] Quando Lao-Tse diz "Todos os seres são claros, só eu sou turvo" exprime o que sinto em minha idade avançada [...] expressando o que eu agora sinto, na idade avançada [...] Assim, a idade avançada é... uma limitação, um estreitamento. $\mathrm{E}$, no entanto, acrescentou em mim tantas coisas: as plantas, os animais, as nuvens, o dia e a noite e o eterno no homem. Quanto mais se acentuou a incerteza em relação a mim mesmo, mais aumentou meu sentimento de parentesco com as coisas. Sim, é como se essa estranheza que há tanto tempo me separava do mundo tivesse agora se interiorizado, revelando-me uma dimensão desconhecida e inesperada de mim mesmo. (Jung, 1961/1988, pp. 309-310)

\subsubsection{A Morte e a Vida Pós-Morte}

Jung observou que os idosos que mais temiam a morte foram jovens que temiam a vida, que se amedrontavam frente às dificuldades e às situações que fazem parte da realidade.

A partir da noção de vida como um processo energético, irreversível e direcionado para um objetivo, Jung considera a morte como o fim desse processo. Ainda relacionando nossa vida com uma curva parabólica, em que nascimento e morte são pontos opostos, Jung (1971/1984) ressalta que "o impulso teleológico da vida não cessa quando se atinge o amadurecimento e o zênite da vida biológica. [...] porque a meta não está no cume, mas no vale, onde a subida começou" (par. 798).

A vida natural é o solo em que se nutre a alma. Quem não consegue acompanhar essa vida, permanece enrijecido e parado em pleno ar. É por isso que muitas pessoas se petrificam na idade madura, olham para trás e se agarram ao passado, com um medo secreto da morte no coração. [...] do meio da vida em diante, só aquele que se dispõe a morrer conserva a vitalidade, porque na hora secreta do meio-dia inverte-se a parábola e nasce a morte. A segunda metade da vida não significa subida, expansão, crescimento, exuberância, mas morte, porque o seu alvo é o seu término. A recusa em aceitar a plenitude da vida equivale a não aceitar o seu fim. (Jung, 1971/1984, par. 800)

A respeito da vida depois da morte, Jung não tem uma teoria, mas sim idéias que não concebe como verdadeiras ou falsas, mas como pensamentos que emergem e que precisam ser levados em conta, sem preconceitos ou posturas racionais que não ajudam na sua compreensão. 
Jung (1961/1988) lembra que, para muitas pessoas, a questão da imortalidade é premente e profunda e não pode ser desconsiderada. A razão não oferece condições para que esse nível de existência seja compreendido, mas o inconsciente, por conter um espaço e tempo próprios, tem melhores fontes de informação.

[sobre o sonho de uma pessoa que temia a morte] Ora, o problema da morte deveria constituir o "centro de interesse" essencial para o homem que está envelhecendo, como também a oportunidade de familiarizar-se precisamente com essa possibilidade. Uma inelutável interrogação lhe é colocada e é necessário uma resposta de sua parte. Para esse fim ele deveria dispor de um mito da morte, porque a "razão" só lhe oferece o fosso escuro no qual está prestes a entrar; o mito poderia colocar sob seus olhos outras imagens, imagens auxiliares e enriquecedoras da vida no país dos mortos. Quem acredita nisso ou lhe concede algum crédito tem tanta razão como aquele que não crê. Mas aquele que nega avança para o nada; o outro, o que obedece ao arquétipo, segue os traços da vida até à morte. Certamente um e outro estão na incerteza, mas um vai contra o instinto, enquanto o outro caminha com ele, o que constitui uma diferença e uma vantagem para o segundo. (Jung, 1961/1988, pp. 265-266) [grifos do autor]

A questão da imortalidade nos remete à religião. Jung considera a religião como um fenômeno válido, genuíno, mas cujo conceito não se assemelha ao de uma religião dogmática. Ele refere que as religiões e seus símbolos provêm do inconsciente e sua função básica é criar um sistema de preparações para a morte, pois admitem que o significado da existência só se afirma e se completa com o seu término: a morte é a realização plena do sentido da vida e sua verdadeira meta.

Jung, filho de pastor protestante e com vários tios pastores, desde a infância sentia conflitos em relação aos ensinamentos que the foram passados de forma dogmática a respeito de Deus e a sua experiência subjetiva de Deus.

Foi uma experiência do numinoso na infância, a partir de uma visão de Deus sentado em um trono de ouro e um excremento enorme caindo sobre o teto de uma igreja, que Jung sentiu alívio em relação a esse conflito e experimentou o significado de Deus dentro de si mesmo.

Para ele, o homem é naturalmente religioso e essa religiosidade é inerente à sua psique, uma função tão forte e natural como os instintos sexuais e agressivos.

A religião, utilizada por Jung no sentido de religio, isto é, de re-ligação do consciente com determinados fatores do inconsciente - fatores estes dotados de 
alta carga energética e acentuado dinamismo, é vista como uma atitude da mente. Como diz Samuels, Shorter \& Plaut (1988) "é uma cuidadosa consideração e observação com relação a certos 'poderes': espíritos, demônios, deuses, leis, ideais - ou, na realidade, uma atitude com relação a qualquer coisa que impressionasse uma pessoa o bastante para mobilizá-la à adoração, obediência, reverência e amor" (p.188). Von Franz (1999) afirma que "esse tipo de consideração cuidadosa pressupõe certa atitude humilde, sincera e simples da consciência em face do numinosum, atitude essa, que no caso de muitas pessoas exigirá grande esforço" ( $p$. 225) [grifo da autora].

Jung afirma que o termo "religião" não abrange credo ou dogma, mas implica uma atitude singular da consciência que sofreu transformação por ter sido tocada por uma experiência numinosa; o autoconhecimento representando uma condição essencial para a vivência dessa experiência.

Uma resposta positiva ao problema da experiência religiosa apenas pode-se oferecer se o homem estiver disposto a satisfazer as exigências de um exame e conhecimento rigoroso de si mesmo. Se assim fizer, não só descobrirá algumas verdades importantes sobre si mesmo, mas também obterá uma vantagem psicológica: terá conseguido julgar a si mesmo como pessoa digna de toda consideração e simpatia. [...] $\mathrm{O}$ inconsciente é somente o meio do qual parece brotar a experiência religiosa. (Jung, 1974/1988, par. 565)

Samuels, Shorter \& Plaut (1988) assinala que a experiência do numinoso depende de uma abertura do indivíduo para vivê-la, pois ela "é mais que uma experiência de uma força tremenda e compulsiva; é um confronto com uma força que encerra um SIGNIFICADO ainda não revelado, atrativo e profético ou fatídico" (p. 136) [grifo do autor].

É a religião que nos conecta com o mito eterno, e é justamente isso que a torna universal e válida para toda humanidade.

Deus, para Jung (1974/1988), era "uma experiência imediata das mais certas", e nos últimos anos declarou que não precisava acreditar em Deus, ele "sabia"; o próprio numinoso correspondendo a uma imagem de Deus no homem.

Quanto à existência de Deus, Jung afirma

Esta questão (da existência de Deus), na verdade, é vã, pois a numinosidade subjetiva, poderosa e radical da vivência é por si só 
uma resposta. Quem teve essa vivência, fez a experiência de ser tomado, sendo por isso incapaz de tecer considerações de ordem metafísica ou epistemológica. Aquilo que tem o máximo grau de certeza é evidente em si mesmo e não necessita de provas antropomórficas. (Jung, 1974/1988, par. 566) [grifo do autor]

Dentro de nós é o self que representa a imagem de Deus, é o princípio que orienta e ordena a personalidade e que reflete a totalidade psíquica, cabendo à função transcendente, através do símbolo, fazer a ponte entre o homem e Deus, ou entre o indivíduo e a sua essência.

O próprio processo de individuação contempla uma significação religiosa na medida em que representa uma busca de realização que só pode se processar quando o indivíduo, a partir do seu esforço pessoal, busca equilibrar os opostos dentro de si mesmo.

A função religiosa pode se manifestar de muitas formas diferentes, em função das mudanças culturais e sociais. Silveira (1971) lembra que "Como toda função, a religiosidade é suscetível de ser desenvolvida, cultivada e aprofundada, e poderá também ser negligenciada, deturpada ou reprimida" (p. 143).

Esta autora aponta também que a vivência direta do numinoso pode representar perigo, caso o indivíduo não tenha uma estruturação de personalidade saudável. Daí a importância dos rituais como elementos protetores que "funcionam como anteparo entre o divino e o humano, isto é, entre o arquétipo da imagem de Deus, presente no inconsciente coletivo e o ego" (p.150). [grifos da autora]. Jung (1971/1978) afirma que em todos os seus pacientes que estavam na metanóia o problema central estava relacionado à sua atitude religiosa. Sua doença era decorrente da perda daquilo que uma religião viva sempre fornecera, e sua cura só poderia se processar através do resgate dessa atitude religiosa autêntica, o que independe da vinculação com uma determinada igreja ou credo.

Acerca dos valores religiosos, como a existência do bem e do mal, Whitmont (1991) afirma que "nenhum impulso ou motivação é em si bom ou mau. A maneira como lidamos com ele é que Ihe confere tal atributo" (p. 251). Jung (1974/1993) assinala que é difícil dizer o que é exatamente algo mau, e que, muitas vezes, o que nos parece mau, na verdade não o é. Só Deus teria o conhecimento do bem e do mal, e nós, humanos, com um conhecimento apenas superficial do mundo, teríamos apenas um conhecimento abstrato sobre o bem e o mal. 
Para Whitmont (1991), "bem e mal são avaliações emocionais que surgem das profundezas da psique, não havendo padrões fixos capazes de nos permitir prever de modo racional se uma dada situação em particular será um bem ou um mal" (p. 252).

Esse mesmo autor lembra que o que é realmente nocivo para o ser humano é a não aceitação em "colaborar com o crescimento e com as exigências da vida, as próprias e as alheias - e o intento consciente e deliberado de destruir ou ferir por mera satisfação pessoal” (p. 251).

O enfrentamento da velhice e da morte faz, portanto, parte desse movimento visando ao crescimento.

Jung, sobre a relação do idoso com a morte, afirma que, na verdade, a natureza nos prepara para a morte e isto é perceptível quando o idoso, mesmo tendendo a olhar para trás, apresenta idéias que antecipam o futuro, inclusive a morte.

Com o andar dos anos, acumulam-se assustadoramente os pensamentos sobre a morte. O homem que envelhece - quer queira quer não - prepara-se para a morte. Por isso eu penso que a própria natureza se prepara para o fim. [...] De fato, é tão neurótico não se orientar, na velhice, para a morte como um fim, quanto reprimir, na juventude, fantasias que se ocupam com o futuro. (Jung, 1971/1984, par. 808)

Frey-Rohn (1989), a partir de seus estudos sobre a experiência da morte, aponta que é muito importante que a pessoa, ao se confrontar com a sua morte, valorize o campo simbólico contido nessa experiência, pois é este contato que possibilitará a elaboração do processo de transformação e a conexão com a totalidade na qual está inserida.

A partir de suas experiências com os sonhos, Jung refere que após a morte haveria continuação do desenvolvimento espiritual, e, portanto, o nível de consciência atingido na vida terrestre seria a base a partir da qual o crescimento poderia continuar na vida pós-morte.

Em sua autobiografia (1961/1988) Jung ainda reflete sobre a coexistência de dois pontos de vista diferentes sobre a morte: como uma terrível brutalidade e como um evento alegre em que "a alma recupera a metade que lhe falta e atinge a totalidade" (pp. 272-273). 
A respeito dos diferentes mitos sobre a vida após a morte, Jung, na mesma obra, se refere à reencarnação e ao carma, não se propondo a responder sobre a relação entre essas duas idéias, considerando-as obscuras. "Quando morrer meus atos me seguirão. É pelo menos, o que imagino. Levarei comigo o que fiz, tendo a esperança, contudo, de não chegar ao fim de meus dias com as mãos vazias" (p. 275).

Ainda sobre suas idéias da vida pós-morte, Jung sugere que esta seria próxima da vida da psique em que o espaço e o tempo não existem e predominam as imagens.

Do ponto de vista psicológico, a "vida no além" aparece como uma seqüência lógica da vida psíquica na velhice. Com efeito, à medida que o homem progride em idade, a contemplação, a reflexão e as imagens interiores desempenham, o que é natural, um papel cada vez maior [...]. Na velhice deixamos que as lembranças se desenrolem diante do olho interior e encontramo-nos a nós mesmos através das imagens interiores e exteriores do passado. É como se fosse o primeiro passo, uma preparação para a existência no além [...] (Jung, 1961/1988, p. 277) [grifos do autor]

Se alguma coisa em nós se mantém eternamente ou não, Jung assume não ter condições de afirmar nada a respeito, mas chama nossa atenção para o fato de que é a partir do critério de se aceitar ou não o infinito que a nossa vida pode ter sentido: se considerarmos o infinito como essencial, a nossa avaliação das coisas do dia-a-dia terá um peso menor e relativo, caso contrário, se estivermos nesta vida não ligados ao infinito, nossas motivações e ações se alteram.

Se compreendermos e sentirmos que já nesta vida estamos relacionados com o infinito, os desejos e atitudes se modificam. Finalmente, só valemos pelo essencial e se não acedemos a ele a vida foi desperdiçada. Em nossas relações com os outros é também decisivo saber se o infinito se exprime ou não. Mas só alcanço o sentimento do ilimitado se me limito ao extremo. A maior limitação do homem é o Si mesmo [...]. Somente a consciência de minha estreita limitação no meu Si mesmo me vincula ao ilimitado do inconsciente. $\dot{E}$ quando me torno consciente disso que me sinto ao mesmo tempo limitado e eterno. (Jung, 1961/1988, pp. 281-282)

“Espaço e tempo não são as certezas mais imediatas e mais primitivas, como são também empiricamente observáveis, porque tudo o que é perceptível acontece como se estivesse no tempo e no espaço" (Jung, 1971/1984, par. 814). Este é o 
campo da consciência, mas é possível, segundo Jung, que a psique possa abranger uma dimensão independente do espaço e tempo que conhecemos conscientemente. Essas idéias, expressas aos 59 anos, foram, após cerca de vinte e cinco anos mais tarde, retomadas confirmando a noção de que o tempo e espaço não eram essenciais para a psique e que "até certo ponto, a alma não está sujeita à mutação e à transitoriedade". (Jaffé, 1989, p. 20).

A respeito da atitude da consciência com o processo de morrer, Jung (1971/1984) ressalta que a limitação da consciência no tempo e no espaço é uma realidade inquestionável, e tal característica, se de um lado favorece o conhecimento consciente, de outro impossibilita o verdadeiro conhecimento do processo psíquico como um processo contínuo. Só a psique inconsciente, por sua "natureza transespacial e transtemporal" (par. 813) tem condições de transpor as barreiras espaço-temporais e se interligar àquilo que é eterno.

Como já foi mencionado, Jung não teorizava e não buscava explicações científicas para suas considerações a respeito da morte e da vida pós-morte, apenas se propunha a apresentar suas idéias seja na sua autobiografia, seja nas cartas que trocava com diferentes interlocutores. Nestas últimas (Jaffé, Frey-Rohn \& Von Franz, 1989), Jung expunha como compreendia a vida, o próprio envelhecimento e sua dificuldade de aceitar a morte: as semelhanças que via entre o desejo de viver e o de morrer, o fato de o processo de individuação ser uma preparação para a morte, a noção de que a "morte é o 'desapego' total, a anulação do Eu e do mundo consciente do interior de um não-Eu desconhecido e sombrio" (p. 13) [grifo do autor]. A vida, para Jung, seria então "um breve episódio entre dois grandes mistérios que, de fato, se resumem em apenas um [...] um recorte da existência entre eternidade e eternidade" (p. 15), em que o mistério encobre tanto o antes, como o sentido da vida, como o depois.

Em uma carta para o Dr. J. Fierz, datada de 21/11/1956, Jung, aos 69 anos, escreveu.

Em meu longo caminho encontram-se embrulhos descartados, testemunhos de numerosas trocas de pele, inclusive essas relicta que se chamam livros. Eles revelam tanto quanto escondem. Cada degrau é símbolo dos próximos. Quem sobe uma escada não demora nos degraus nem olha para trás sobre eles, mesmo que a idade convide a demorar ou a retardar o passo. O grande vento do cume sussurra com maior veemência. Os últimos degraus são os 
mais belos e os mais preciosos pois conduzem àquela plenitude para a qual nasceu a essência mais íntima da pessoa. (Jung,1972/2002, Vol.1, p. 407) [grifo do autor].

Tal fala não exclui outras que revelam a sua percepção do lado trágico da morte, quando esta leva pessoas queridas muito cedo ou quando suas vidas não estão totalmente realizadas. Aos 71 anos, confessou sentir medo frente às limitações físicas e à proximidade da morte, temendo uma doença prolongada, sentindo nesta ocasião que seu processo de individuação ainda precisava ser completado.

Aos 78 anos, em uma carta a Aniela Jaffé (Jung, 1972/2002, Vol. 2), revelou a sua dor frente à consciência da sua mortalidade.

Um ano antes da sua morte Jung, embora lúcido, percebia que se sentia num processo de progressivo desligamento do tempo e do espaço da nossa realidade, como se sua "alma já estivesse retornando ao misterioso solo do seu Ser, fora do tempo e do espaço. Apesar de todos os momentos depressivos, isso conferia a Jung uma sensação fundamental de alegria".(Jaffé, 1989, p. 23).

Nesta época, em carta endereçada a Earl von Sandwich, Jung escreveu.

A velhice tem apenas a metade da graça que se costuma atribuirIhe. De qualquer modo é a gradual sucumbência da máquina corporal, com que nos identifica a loucura. Exige de fato um esforço gigantesco - a magnum opus - escapar a tempo do aperto de seu abraço e libertar nossa mente para a visão da imensidade do mundo do qual constituímos uma parte infinitesimal. Apesar da enormidade de nosso conhecimento científico, estamos apenas ao pé da escada, mas ao menos já chegamos ao ponto de reconhecer a insignificância de nosso saber. (Jung, 1972/2002, Vol. 3, p. 277) [grifos do autor]

\subsection{A visão de Hillman: o envelhecimento como momento de moldar a força do caráter}

\subsubsection{Um Breve Olhar sobre a Psicologia Arquetípica}

No início de 1970, James Hillman fundou a escola de "psicologia arquetípica" ou "psicologia imaginal" numa tentativa de elaborar de forma crítica a teoria e a 
prática propostas originalmente por Jung. A característica principal dessa abordagem é a valorização do imagético, o imaginal sendo considerado tão real quanto a realidade externa. Para os pós-junguianos que seguem as propostas de Hillman toda e qualquer imagem, por mais simples que seja, pode ser considerada arquetípica.

Segundo Adams (2002), "Para expressar o que pretende, a psique seleciona uma imagem particularmente adequada de todas as imagens disponíveis na experiência do indivíduo para servir a uma finalidade metafórica bastante específica" (p. 114). O método utilizado durante a análise envolve o estímulo à imaginação e a atenção às imagens que emergem. Hillman concede mais autonomia à imaginação do que Jung concedia originalmente, e basicamente propõe que se atente à imagem como fenômeno em si, descartando a interpretação e a tendência de abordar o fenômeno intelectualmente.

Para Hillman (citado por Adams, 2002), a psicologia imaginal é considerada uma psicologia da alma, termo este que contempla "vulnerabilidade, melancolia e profundidade [...] A feitura da alma no mundo envolve um aprofundamento da experiência, no qual o ego é rebaixado e aí mantido. [...] a psicologia imaginal enfatiza que não apenas os indivíduos têm alma mas que o mundo tem alma - ou que os objetos materiais no mundo têm alma" (p. 121).

Em sua obra O código do ser, Hillman (1997) desenvolve a "teoria da semente de carvalho" em que discorre sobre a idéia de que cada vida é formada por uma vocação, que traz em seu cerne todas as possibilidades que serão desenvolvidas futuramente, tal como a semente que contém o destino do carvalho adulto. Ainda nesse livro Hillman afirma que cada pessoa deve descobrir o seu daimon, aquilo que está registrado dentro de si e que faz parte da sua singularidade, e suas possibilidades de desenvolvimento. A busca do caráter e da vocação pessoal é uma exigência da vida, não havendo como fugir desse "chamado".

\subsubsection{O Envelhecimento e a Necessidade da Alma}

A ampliação dessas idéias para o estudo do envelhecimento faz com que Hillman (2001) afirme que a velhice não é acidental, ao contrário, é necessária à 
condição humana, uma necessidade da alma para que o seu desenvolvimento se complete. "O caráter necessita desses anos adicionais [...] Os últimos anos confirmam e realizam o caráter" (p. 11).

Para esse autor, a explicação de como o envelhecimento ocorre baseia-se nos estudos da biologia, genética, fisiologia e outras áreas da ciência, mas a compreensão do envelhecimento exige que a idéia do caráter seja levada em conta.

O caráter age como uma força orientadora.

O caráter atua como um instinto subjacente, sublinhando incisivamente as ações que cometemos, as palavras que dizemos, marcando o estilo delas. É uma força imaginadora, e é preciso ter inteligência imaginativa para rastrear suas marcas.[...] O caráter é sempre qualificado. Ele é feito de traços, imagens, qualidades. Por definição, o caráter refere-se às marcas que o distinguem e que tornam uma coisa reconhecivelmente diferente de todas as outras coisas. Cada caráter se mantém coeso pelas qualidades que lhe são peculiares. Ele é necessariamente limitado por seus próprios qualificativos. (Hillman, 2001, pp. 207-208)

É do caráter que emerge a ética com uma particularidade e peculiaridade próprias. O caráter de cada pessoa contém tanto o bem como o mal, os valores e os traços que são duradouros, que muitas vezes tentamos inclusive esconder, e cuja existência não depende da nossa vontade consciente mantê-los ou corrigi-los.

Hillman (2001) complementa afirmando que o caráter ganha vida tanto com elementos do corpo como da alma.

Muito antes de termos partido, já temos em nós um emaranhado de imagens que comprimem nossa complexidade na forma de um "caráter", afetando as outras pessoas como uma força vital imaginativa. [...] Assim o que fica de nós depois que partimos é o caráter, a imagem em camadas que desde o início vinha dando forma aos nossos potenciais e limites. Os anos da velhice definem mais claramente esse caráter à medida que as histórias repetitivas e as fantasias eróticas, as vigílias noturnas e a busca insistente através dos corredores da memória forçam sobre nós a singularidade do nosso caráter. (Hillman, 2001, pp.186-187) [grifos do autor]

O modo como a pessoa envelhece, o seu comportamento diário e o estilo da sua imagem revelam o seu caráter em funcionamento. "Assim como o caráter dirige o envelhecimento, o envelhecimento revela o caráter" (p. 15). As singularidades que 
uma pessoa tenta abafar durante sua vida vêm à tona na velhice para compor a imagem que é deixada.

Quando ficamos atentos ao nosso caráter e ao dos outros estamos na verdade buscando conhecer a essência que pode se manifestar a qualquer momento, desde que tenhamos um olhar experiente que vá além dos fatos e comportamentos aparentes.

Hillman (2001) salienta que o que torna a velhice feia não é a velhice em si, mas o distanciamento da força orientadora que existe em todos nós, o abandono do caráter. Esse autor acrescenta que olhar a velhice através dos estudos da fisiologia limita a nossa percepção e impede que captemos a beleza dessa fase, cujos conflitos são antigos. Na mitologia, podemos ver no confronto entre Hércules e Geras, figura que personificava a velhice entre os gregos, um clássico confronto do herói arquetípico com uma imagem do envelhecimento.

Hoje a luta heróica contra o envelhecimento assume novas facetas, as vitaminas e os tratamentos anti-envelhecimento e as promessas de juventude eterna revelam que a essência da luta está mais viva do que nunca, porque ela é mítica. A principal patologia da velhice, para esse autor, é a nossa idéia da velhice. Envelhecer, atualmente, tornou-se o maior medo de uma geração.

Platão (1984) menciona o diálogo entre Sócrates e Céfalo em que este, ao ser questionado sobre a sua idéia de velhice, afirma que a única causa para as queixas dos idosos não é o envelhecimento em si, mas o caráter do homem e os defeitos do caráter que sempre existiram nele, e as qualidades, que geralmente são tidas como inerentes ao processo de envelhecimento, têm suas raízes no caráter e fazem parte do indivíduo desde sempre.

Hillman (2001) chama atenção para o fato de que, ao buscarmos o prolongamento da vida de forma numérica, inevitavelmente estamos tentando afastar o fantasma do fim da nossa existência e colocar a morte atrás do muro. $\mathrm{O}$ tempo não é apenas destrutivo, diz esse autor, ele segue sempre em frente, ora fortalecendo, ora debilitando, portanto, não é ele o inimigo que deve ser destruído.

A questão do tempo na velhice é muito importante. Para o idoso é como se um pedaço da sua alma estivesse sempre ancorado no passado, e esta necessitasse retornar, tentando alternar o fluxo do tempo que é, na verdade, inexorável. 
Daí o mito do eterno retorno que parte da premissa de que o tempo é cíclico. O corpo na sua humanidade tende a viver o tempo secular, tomando a direção reta, enquanto a alma, vivendo a partir do tempo sagrado, move-se em círculos em direção a si mesma, sempre visando ao seu desenvolvimento contínuo.

Se queremos que a nossa vida não se desvie demais da nossa alma, precisamos fazer constantemente pequenos ajustes para que nossa linha de ação não se afaste do círculo da alma. Nesses ajustes constantes pelos quais tentamos manter a alma e o corpo em contato, somos muito parecidos com o marujo que segura o timão, corrigindo o curso para um lado e para o outro, o dia inteiro. 0 marujo sabe que nunca está totalmente no curso certo, sempre um pouquinho desviado, sempre precisando de pequenos ajustes. (Hillman, 2001, p. 158)

Outro mito muito importante é o da imortalidade. Se nos tornamos imortais nos igualamos a Deus, mas nossa essência é outra: somos mortais e temos os mais diversos limites. Hilman fala então em "durabilidade": quanto mais uma pessoa "dura", mais ela quer perdurar e este desejo tráz em si o sentido de vencer a morte.

O mesmo autor assinala que se mudarmos o termo perdurar para partir mudará também a nossa atitude básica, de agarrar-nos para soltar-nos. Perdurar, afirma ele, parece estar relacionado ao nosso instinto de autopreservação, e a nossa partida é sentida como uma derrota, e não como um momento de transformação como outros na nossa vida.

A mudança de perdurar para partir muda a nossa atitude básica, de agarrar-nos para soltar-nos. É uma grande troca de paradigma, um movimento de arquétipos. Perdurar nos sustentou porque expressa o instinto de autopreservação, que é considerado "a primeira lei da natureza”. A sensação é de que a própria vida quer perdurar, sentimos que partir é uma derrota. [...] O inevitável chegou; partir só pode significar uma coisa: morrer.[...] O que está morrendo, no entanto, é o compromisso de nos agarrarmos a essas atitudes que pertencem a perdurar e que até agora nos preservaram. (Hillman, 2001, p.83) [grifos do autor]

E qual é então o papel do idoso nesse caminho?

Hillman (2001) afirma que cabe ao idoso desempenhar o papel que os velhos sempre desempenharam: preservar e transmitir o conhecimento e moldar nas defesas da vida real a força do caráter.

Esse autor acrescenta 
$\mathrm{Na}$ velhice, os sentimentos de altruísmo e bondade para com as pessoas desconhecidas desempenham um papel maior, como se os fatores psicológicos e culturais redirecionassem, ou até mesmo dominassem, a herança genética e seu propósito de propagação. O caráter começa a dominar as decisões da vida cada vez com mais pertinência, e permanentemente. Os valores são submetidos a mais escrutínios, e qualidades tais como decência e gratidão tornam-se mais preciosas do que acuidade e eficiência [...] (Hillman, 2001, p. 85)

Os últimos anos são importantes para uma revisão de vida e para corrigir erros, para "especulações cósmicas e para transformar lembranças em histórias, para usufruir sensorialmente as imagens do mundo e para ligar-se a espíritos e a ancestrais - valores que a nossa cultura deixou fenecer" (p. 47). O idoso só poderá servir à sociedade se o seu caráter refinou sua inteligência, ampliou o seu conhecimento e foi testado em crises.

Quando nos reportamos a esse papel do idoso e à importância da força do caráter, fica difícil entender a ênfase que é dada apenas à duração e ao aumento das estatísticas de expectativa de vida. A idéia de longevidade deve contemplar também a compreensão da velhice como um estado de ser e o "velho" como um fenômeno arquetípico, com seus próprios mitos e significados.

A partir dessa idéia, pode-se constatar que a gerontologia, ciência que é um produto do século $X X$ e que focaliza a biologia do envelhecimento, não aborda de forma ampla e profunda o caráter do idoso. Hillman (2001) pontua que "uma ciência do envelhecimento que começa com a fisiologia da mudança em vez de começar com a sua importância para o indivíduo não está falando com a pessoa que envelhece" (p. 85).

Concordamos com Hillman quando este diz que é necessária uma revolução no estudo da velhice e que este deve ir além dos modelos e atitudes da ciência. Corroborando a visão desse autor, entendemos que a saída seria um enfoque mais humanista, direcionando nossas pesquisas para "aquilo que mais nutre a velhice: companheirismo, liberdade, todas as artes, natureza, silêncio, serviço, simplicidade e segurança" (p. 86).

Neste sentido, percebo o quanto a Psicologia Analítica pode colaborar para que compreendamos o processo de envelhecimento de forma mais profunda e completa, e possamos propor novas formas de intervenção que propiciem que o 
idoso siga desenvolvendo suas potencialidades e, dessa forma, levem, até o fim, a experiência da própria vida.

Como bem diz Hillman:

Envelhecer não é um acidente. É algo necessário à condição humana e pretendido pela alma [...]. Não posso apoiar a teoria de que a longevidade humana é o resultado artificial da civilização, sua ciência e suas redes sociais, produzindo uma safra de múmias vivas, paradoxos suspensos numa zona crepuscular [...] os últimos anos confirmam e realizam o caráter. (Hillman, 2001, p.11) 


\section{CAPÍTULO IV}

\section{CONTRIBUIÇÕES DA PSICANÁLISE}

\subsection{Breve Histórico}

O desenvolvimento da Psicoterapia Breve deu-se no período pós-guerra, a partir da tentativa de psicanalistas que questionavam 0 processo psicanalítico tradicional. Lemgruber (1984) assinala que a Psicoterapia Breve "surgiu como o único tratamento adequado às necessidades da guerra, com objetivos específicos ligados à remoção ou melhora dos sintomas podendo atender mais prontamente à demanda da população gerada pelo aumento da necessidade de serviços psicoterápicos" (p. 30).

Esse tipo de tratamento tornou-se uma importante alternativa de intervenção clínico-institucional em função da grande procura por atendimentos que não fossem tão onerosos e longos quanto os tradicionais.

A literatura (Yoshida, 1990; Melo, 1998, entre outros) apresenta vários eixos teóricos que podem fundamentar a Psicoterapia Breve: a teoria psicanalítica, a fenomenológica-existencial, a cognitiva e a teoria junguiana.

No desenvolvimento histórico da Psicoterapia Breve, o trabalho de Freud tem uma importância inquestionável, seja pela reflexão sobre o significado da duração de um processo analítico, seja pela importância dada à relação terapeuta-paciente. Freud, já na Conferência de Budapeste, em 1918, chamou atenção para a necessidade de um tipo de intervenção que fosse mais acessível à população. Ferenczi, um dos precursores da Psicoterapia Breve, em 1926, destacou que um bom vínculo terapeuta-paciente favoreceria uma atuação mais ativa por parte do terapeuta, o que agilizaria o processo psicoterápico dos pacientes muito resistentes. Otto Rank focalizou a questão da Separação-Individuação, considerando que o tempo limitado poderia favorecer a elaboração dos conflitos relacionados à separação. Lemgruber (1997), citando Franz Alexander, refere que a Noção de Experiência Emocional Corretiva envolveria a exposição do paciente, em condições 
mais satisfatórias, a situações emocionais que não puderam ser resolvidas anteriormente. Neste caso, a atuação do terapeuta poderia ser mais adequada pois esta se basearia numa avaliação da personalidade e dos problemas que o paciente estivesse enfrentando. A Psicoterapia Breve, a partir dessas contribuições, passou a ser vista como um tipo de intervenção que, mesmo tendo um tempo reduzido, não é superficial, ao contrário, a mudança na relação terapêutica favorece que o paciente reestruture suas vivências passadas e que seu processo seja agilizado.

A Psicoterapia Breve, então, pode ser conceituada, de modo geral, como uma técnica com características bem definidas, incluindo o tempo limitado, a delimitação do foco e o planejamento estratégico. Esta modalidade de tratamento, portanto, não visa à reestruturação da personalidade, mas sim a uma melhora do padrão adaptativo em um momento de crise, sendo um fator primordial a motivação do paciente.

Apresento aqui as idéias desenvolvidas por dois grandes psicanalistas, considerando que os conceitos por eles articulados podem trazer contribuições importantes para a fundamentação teórica da Psicoterapia Breve de Orientação Junguiana.

\subsection{Contribuições de Malan}

Em 1963, Malan, a partir de observações importantes sobre a psicoterapia psicanalítica e a possibilidade de esta fornecer a base para uma psicoterapia focal, apresentou um vasto trabalho em que analisava as propostas de terapeutas conservadores e de terapeutas radicais. Estes propunham uma Psicoterapia Breve de base psicanalítica que poderia, a partir da adoção alguns critérios, alcançar resultados satisfatórios e permanentes.

O mérito de Malan, a partir de pesquisas e de atendimento clínico, foi afirmar que era possível fazer uma Psicoterapia Breve de base psicanalítica.

Malan (1981) assinala que um grande número de pessoas precisa ser ajudado devido a doenças mentais, faltando-lhes condições financeiras e tempo para que esse tratamento se desenvolva a contento. Esse mesmo autor, a respeito da aplicação prática dos métodos de Psicoterapia Breve, lembra os trabalhos de 
Caplan (1966) sobre a importância do tratamento durante a crise e a visão desta como uma oportunidade de crescimento. O emprego de métodos de Psicoterapia Breve com pacientes fora de crise também se revelou eficaz, conforme vários estudos apresentados por Malan (1981).

Este mesmo autor, citando as contribuições de Sifneos à prática da Psicoterapia Breve, relaciona os critérios de seleção: a motivação do paciente, o uso da palavra foco e a delimitação dos sintomas neuróticos. Outros critérios adicionais são assinalados, tais como, ter inteligência acima da média, ter desenvolvido pelo menos uma relação significativa com outra pessoa, uma crise emocional, capacidade de interagir bem com o terapeuta e de expressar sentimentos, motivação para engajar-se no tratamento psicoterápico e apresentar uma queixa principal específica. Em relação à motivação, Malan enfatiza que esta deve, além de estar relacionada ao tratamento, estar direcionada ao insight.

Nessa mesma obra, Malan, identificando-se com Sifneos, considera que a presença de uma psicopatologia grave não contra-indicaria a terapia breve, e relata que ele mesmo obteve êxito em pacientes com psicopatologia severa.

A visão inicial preconceituosa de que a Psicoterapia Breve obtinha resultados temporários e paliativos, foi gradativamente sendo alterada no sentido de que ela poderia ser indicada a pacientes com conflitos atuais agudos, e que a resolução desses conflitos poderia levar a uma mudança permanente, favorecendo a retomada do desenvolvimento psíquico.

Outro critério importante destacado por Malan (1981) refere-se à atuação do terapeuta. Na Psicoterapia Breve, este adota uma atitude ativa, baseada num planejamento feito a partir de um diagnóstico, e direcionada a um determinado objetivo, estabelecido em função do foco. Desta forma, o terapeuta, baseado no foco do tratamento, faz interpretações seletivas e desenvolve uma atenção seletiva para limitar o paciente em suas associações.

Pode-se formular o objetivo limitado em termos de um efeito terapêutico desejado, mas, uma vez serem os efeitos terapêuticos difíceis de prever, provavelmente seja melhor formular o objetivo em termos de uma área específica que necessite ser trabalhada e, desta maneira, um tema específico para interpretações. Como estas dependem do material que o paciente traz, surge a necessidade de uma forma mais tática de "atividade", ou seja, de orientar o paciente durante as consultas por meio de 
interpretações seletivas, atenção seletiva e negligência seletiva. (Malan, 1981, p. 44) [grifos do autor]

Ainda a respeito do foco, termo este introduzido por Balint, Malan (1981) relata que Mann e Sifneos enfatizaram que o foco ou problema central deveria ser definido no início do tratamento, a partir dos dados obtidos na anamnese. Estes autores entendem por foco um tema unificador que possa se constituir na base das interpretações.

Outros pontos importantes que suscitaram muitas controvérsias no uso da Psicoterapia Breve referem-se ao número de sessões, limites de duração e a alta. Malan (1981), em princípio, estabeleceu um limite máximo de quarenta sessões, prazo considerado por ele mesmo como arbitrário, e mostrou-se reticente quanto à delimitação do tempo de tratamento. Os diversos estudiosos da técnica diferem quanto ao número ideal de sessões, mas todos são unânimes ao apontar a necessidade de um limite a ser combinado com o paciente no início do tratamento. Mann (citado por Malan, 1981) constatou a pertinência de se estabelecer um limite de tempo desde o início do tratamento, o que seria benéfico uma vez que a questão da alta já ficaria estabelecida desde o princípio. A respeito desta, Mann salienta que o conhecimento da data para a conclusão do tratamento favorece o aparecimento de conflitos passados e alimenta, após a alta, uma relação terapêutica satisfatória e uma internalização positiva do terapeuta, o que possibilita o desenvolvimento de uma separação madura.

Quanto à avaliação de pacientes para psicoterapia, Malan (1981) enfatiza a importância de se fazer uma avaliação psicodinâmica exaustiva inicial que visa: compreender profundamente a doença do paciente, prever o que acontecerá a ele durante o processo, verificar quem tem condições de usufruir deste tipo de tratamento e, caso não o seja, encaminhá-lo ao tratamento mais adequado, e escolher um planejamento terapêutico. Este último ponto depende da avaliação psicodinâmica que inclui uma história psiquiátrica adequada e uma história psicodinâmica completa, que, muitas vezes, coincide com a anterior.

A história psicodinâmica deve abarcar uma descrição pormenorizada das relações de objeto do paciente e visa compreender as relações emocionais, como elas colaboraram para a doença atual e como o paciente enfrenta as dificuldades e lida com suas ansiedades. Outro aspecto importante desta avaliação está na 
observação da qualidade da própria entrevista, de como se desenvolve o relacionamento paciente-entrevistador.

Embora Malan considere interessante que se façam interpretações, assinala que estas devem ser cuidadosamente elaboradas, visando atingir os objetivos da entrevista avaliativa.

A motivação do paciente é também considerada um fator fundamental nessa fase de avaliação, pois uma forte motivação pode favorecer um bom desenvolvimento do tratamento breve.

Ao final do levantamento da história psiquiátrica e da história psicodinâmica, o terapeuta é capaz de fazer um diagnóstico psicodinâmico completo, com condições de verificar se o paciente apresenta algum sintoma patológico significativo que deva ser levado em conta no desenvolvimento do planejamento terapêutico, de avaliar a capacidade do paciente ter insight e de compreender as interpretações e responder a elas, seus recursos internos para lidar com situações ansiógenas e sua motivação para lidar com fases difíceis inerentes ao tratamento e ir até o fim do mesmo.

Ainda a respeito do trabalho de Malan (1981), é importante relacionar os critérios usados por este autor para avaliar aqueles pacientes considerados inadequados para a Psicoterapia Breve. As condições abaixo relacionadas, que acarretavam a recusa do paciente para um tratamento breve, foram extraídas da obra de Malan (1981): incapacidade de estabelecer contato; necessidade de um tratamento prolongado com a finalidade de gerar motivação no tratamento; necessidade de trabalho prolongado a fim de penetrar defesas rígidas (o perigo específico em relação a essas condições seria a incapacidade de iniciar um tratamento efetivo em curto prazo); inevitável envolvimento em questões complexas e profundamente arraigadas, aparentemente sem possibilidades de serem elaboradas em curto prazo; séria dependência ou outras formas de transferência intensa desfavorável (o perigo específico em relação a essas condições seria a dificuldade de concluir o tratamento); intensificação de perturbação depressiva ou psicótica (o perigo aqui seria um surto depressivo ou psicótico).

Malan dava importância tanto aos recursos internos do paciente, já mencionados no início deste trabalho, como aos recursos externos, tais como família, emprego e condições socioeconômicas. 


\subsection{Contribuições de Ryad Simon}

No Brasil, entre outros brilhantes pesquisadores da Psicoterapia Breve, destaca-se o professor Titular Ryad Simon cujo mérito foi ter sistematizado a Psicoterapia Breve.

Simon (2000) enumera os principais fatores que contribuíram para que ocorressem mudanças na prática da psicanálise.

[...] as vicissitudes por que passou a economia brasileira, que concorreram para o empobrecimento da classe média, obrigando-a a reduzir o número de sessões e a reivindicar o barateamento de seu custo, [...] outros fatores concorreram de forma indireta, entre os quais a ampliação das distâncias, os congestionamentos, mudanças culturais e tecnológicas como a internet e a informática que, sobremaneira, intensificaram o desejo de resultados e soluções mais rápidas e exacerbaram a tendência ao consumismo, pois, cada vez mais, um menor número de pessoas tem paciência, o que evidencia uma menor tolerância à frustração. (Simon, 2000, p. 1)

Segundo esse autor, fatores materiais e culturais influenciaram na disposição da clientela. Atualmente temos a pressão da classe média para um tratamento mais acessível, e as pessoas mais carentes necessitando de atendimento emergencial para seu sofrimento psíquico.

Simon (1990) afirma que a Psicoterapia Breve está diretamente ligada a situações de crise. Esse autor (1989) classifica as crises em crises por perda, que se caracterizam por sentimentos de depressão e culpa, e crises por aquisição, em que predominam sentimentos de insegurança, inferioridade e inadequação. Os fatores que acarretam uma crise podem ser os mais diversos, internos ou externos, positivos ou negativos, podendo aumentar ou diminuir as condições adaptativas do paciente. Para esse autor, a Psicoterapia Breve não tem um objetivo ambicioso de resolver totalmente um determinado problema, nem visa à reestruturação da personalidade, mas busca evitar que as dificuldades se estendam e prejudiquem a vida futura, e obter a melhor adaptação possível.

Simon (1990) estabeleceu os pressupostos teóricos da Psicoterapia Breve a partir da noção de que, quando o paciente se encontra em crise, a dor vivida o motiva para superar ou analisar seus problemas emocionais e isto o mobilizaria para 
uma Psicoterapia Breve. A característica fundamental de uma situação de crise é que ela representa o novo, o desestruturante, o desconhecido e, ao mesmo tempo, novas possibilidades de transformação e de crescimento psíquico.

Simon também considera, como Malan, que a Psicoterapia Breve é viável quando o paciente tem recursos intelectuais medianos, tem capacidade de insight e está motivado para o tratamento. Neste tipo de intervenção, o terapeuta tem uma atuação ativa, diretiva, evita associações livres prolongadas, interpreta e, ao mesmo tempo, ajuda o paciente na elaboração. A esse respeito, é importante ressaltar que o cuidado com as interpretações tem que ser redobrado, pois uma interpretação errônea numa Psicoterapia Breve tem um peso maior que numa terapia convencional.

Simon (2000) ainda enfatiza que, conforme as circunstâncias, o terapeuta pode utilizar recursos suportivos, como, por exemplo, a sugestão, reasseguramento, orientação e catarse. Embora a intervenção na Psicoterapia Breve não seja voltada para a transferência, o profissional deve evitar a transferência negativa e estimular a transferência positiva, da qual retira a possibilidade de colaboração e confiança do paciente.

Simon (1989) aponta, como Malan, para a importância do diagnóstico para que a intervenção seja bem desenvolvida. Para isto criou um método de avaliação diagnóstica, a Escala Diagnóstica Adaptativa Operacionalizada (EDAO) que, de forma breve, a partir do critério adaptativo, permite classificar um paciente ou um grupo de pacientes. 


\section{CAPÍTULO V}

\section{DIFERENTES MODALIDADES DE APLICAÇÃO DA PSICOLOGIA ANALÍTICA}

\subsection{Pressupostos Teóricos da Psicoterapia Grupal de Orientação Junguiana}

\subsubsection{Alguns Princípios Gerais das Grupoterapias}

Zimerman (2000), psicanalista especializado em grupoterapia, assinala os requisitos que caracterizam um grupo: a) um grupo não é apenas a soma de pessoas; b) todos os integrantes têm uma meta comum; c) o número de integrantes deve considerar as condições para uma boa comunicação; d) algumas regras, como local apropriado, horário, faltas, na verdade, a constituição de um enquadre deve ser claramente definido; e) o grupo é uma unidade que se manifesta como uma totalidade; f) a preservação da identidade grupal é tão importante quanto a preservação da identidade individual; $\mathbf{g}$ ) a existência de uma relação afetiva entre os integrantes; $\mathbf{h}$ ) a coexistência de forças opostas (de coesão e de desintegração); i) a formação de uma psicodinâmica grupal que contempla medos, ansiedades, fantasias, processos identificatórios etc.

Esse mesmo autor (2000) aponta quatro aspectos importantes relacionados à função de "continente" do grupo: 1. o enquadre grupal se constitui como um "continente"; 2. a capacidade do terapeuta grupal acolher todo tipo de identificações projetivas; 3. cada integrante do grupo deve desenvolver gradativamente a capacidade de ser continente das próprias angústias e das dos seus pares; 4. o próprio grupo, como uma entidade, atua como um importante continente.

Zimerman, na mesma obra, chama atenção para as condições necessárias para um grupoterapeuta: os conhecimentos técnicos e teóricos, as habilidades resultantes da atividade profissional supervisionada e as atitudes do terapeuta que resultam tanto da estrutura da sua personalidade, como de condições pessoais diferenciadas que transcendem sua comunicação verbal. Esse mesmo autor salienta 
a importância do terapeuta grupal gostar de trabalhar com grupos, ter paciência, ser continente, ter capacidade de empatia, ser intuitivo, ter capacidade de discriminar aspectos importantes na dinâmica grupal, ter senso de ética, entre outros atributos.

Em relação a esta pesquisa com idosos, podemos salientar também a importância do terapeuta de grupo gostar de trabalhar com essa faixa etária, o que implica sensibilidade para se comunicar e acolher o idoso em suas particularidades.

Bisker (citado por Osório, 1986) reconhece que os benefícios da psicoterapia grupal são decorrentes tanto do trabalho terapêutico em si, como do processo que se desenvolve fora do âmbito da sessão. Podemos, então, pensar que as conversas antes do início da sessão, como após, também têm efeito terapêutico e fortalecem os vínculos afetivos entre os integrantes do grupo.

\subsubsection{Psicoterapia Grupal de Orientação Junguiana}

Após essa introdução focando as condições necessárias para o desenvolvimento de um processo psicoterápico grupal, considero importante retomar uma das questões centrais desta pesquisa que é o processo de individuação na terceira idade e como uma psicoterapia grupal pode favorecer seu desenvolvimento.

O autoconhecimento, para Jung, não é uma escolha da consciência, mas sim um impulso arquetípico cuja conscientização por parte do ego, juntamente com as influências do meio em que o homem vive, visa ao conhecimento e à autorealização.

Essa busca de conhecimento, que também é arquetípica, e de autoconhecimento está na psicologia junguiana estreitamente ligada à busca de sentido da vida, que é uma das questões centrais do processo de envelhecimento e dos conflitos dessa fase.

As propostas de psicoterapia grupal, a partir de Psicologia Analítica, geralmente encontram críticas questionando a possibilidade de o processo de individuação ocorrer fora do âmbito da terapia individual.

Por que um grupo, de uma forma diferente, não pode propiciar condições para que esse processo se desenvolva? 
A respeito da possibilidade de psicoterapia grupal, Jung, na sua carta ao Dr. Hans A. Illing, datada em 26 de janeiro de 1955, (Jung, 2002, Vol. 2) afirma que qualquer perturbação psíquica (neurose ou psicose) é uma doença individual e, dessa forma, a pessoa deve ser tratada individualmente.

No trabalho grupal, diz ele, a pessoa só é atingida na medida em que é membro do mesmo e isto seria um fator limitante para o processo de individuação. Esta condição, inicialmente, representa um grande alívio, pois, no grupo, a pessoa é protegida pelo grupo e afastada de si mesma, o sentimento de segurança é maior, embora o sentimento de responsabilidade seja menor.

Jung, na mesma carta, aponta que, nas situações grupais, geralmente as pessoas são influenciadas, tanto de forma positiva como negativa, perdendo a liberdade e passando a apresentar comportamentos que por si só nunca apresentariam. A discordância com a posição do grupo levaria a uma situação de pressão por parte deste visando à concordância máxima.

[...] sugestionabilidade elevada significa não liberdade individual, porque o indivíduo está a mercê das influências ambientais, sejam elas boas ou más. A capacidade de discernir está enfraquecida bem como a responsabilidade individual [...]. Mesmo um grupo pequeno é regido por um espírito sugestivo de grupo, que, sendo bom, pode ter efeitos sociais benéficos, às custas no entanto da independência mental e moral do indivíduo. O grupo enaltece o eu, a pessoa tornase mais corajosa, mais pretensiosa, mais segura, mais atrevida e imprudente, mas o si mesmo é minimizado e relegado ao plano de fundo em benefício da média geral [...]. (Jung, 2002, Vol. 2, p. 387) [grifos do autor]

Ainda questionando o tipo de relação que se estabelece no grupo, Jung afirma.

[...] A influência niveladora do grupo sobre o indivíduo é compensada pelo fato de que um deles se identifica com o espírito do grupo e se torna líder. Por isso haverá no grupo sempre conflitos de prestígio e poder que se baseiam no egoísmo exacerbado da pessoa grupal. O egocentrismo social multiplica-se de certa forma com o maior número de membros do grupo. (Jung, 2002, Vol. 2, p. 387) [grifo do autor]

Na mesma carta, a respeito da terapia de grupo, Jung ressalta. 
Não tenho objeções práticas contra a terapia de grupo [...] Eu mesmo fundei há quase 40 anos um grupo, constituído de pessoas "analisadas" com a finalidade de constelar a atitude social do indivíduo. A atitude social não entra em função no funcionamento dialético entre paciente e médico e pode, por isso, ficar num estado de desadaptação, como aconteceu com a maioria dos meus pacientes. Este obstáculo só se manifestou na formação do grupo e precisou de um mútuo polimento. (Jung, 2002, Vol. 2, p. 387) [grifo do autor]

Em outro momento, Jung (1971/1981) menciona que pode haver aspectos positivos nas relações do indivíduo com o grupo, este promovendo coragem e dignidade ao indivíduo.

De modo geral, Jung refere que a terapia de grupo só é capaz de educar a pessoa social, não podendo por isso substituir a terapia individual, cujo processo dialético entre dois indivíduos e a discussão intrapsíquica subseqüente, o diálogo com o inconsciente, são condições básicas para o desenvolvimento psíquico. Concluindo sua argumentação, Jung afirma que a terapia de grupo é necessária para a educação da pessoa social e que ela não substitui a análise individual. Jung salienta que as duas formas de psicoterapia se complementam, mas ressalta que o risco da terapia de grupo é levar o indivíduo a ficar parado no nível coletivo, enquanto o perigo da análise individual é menosprezar sua adaptação social.

Von Franz (1999) reflete sobre essas idéias de Jung pontuando que, se o espírito sugestivo do grupo for bom, poderá haver efeitos sociais positivos, mas que o preço, mesmo assim, seria alto, pois a independência mental e ética do indivíduo ficaria prejudicada.

À medida que o grupo reforça o ego, a pessoa fica mais corajosa, ou até impertinente, mas o Si mesmo é empurrado para os bastidores. É por isso que os fracos e inseguros querem pertencer a organizações. A pessoa então se sente poderosa, mas perde o $\mathbf{S i}$ mesmo (o demônio captura a alma dela) e o discernimento individual. (Von Franz, 1999, p. 317) [grifos da autora]

Quanto às motivações dos analistas para uma terapia grupal, Von Franz (1999) cita que, a seu ver, o maior ganho por sessão e a dificuldade de alguns analistas de lidar com a transferência de seus pacientes têm um peso considerável. $\mathrm{Na}$ terapia grupal geralmente os fenômenos da transferência, para essa autora, são 
enfraquecidos, e isto ajuda a reduzir a pressão das transferências, o que pode prejudicar o tratamento na medida em que a transferência sempre foi considerada por Jung como veículo do processo de individuação, trazendo consigo toda a transformação curativa do indivíduo.

Von Franz ressalta ainda a importância do processo de individuação, baseado na transferência, apontando-o como condição básica do verdadeiro comportamento social. A relação consigo mesmo, afirma esta autora, favorecida pela transferência, é a ponte para um verdadeiro relacionamento com o outro. Jung (1948/1972) considera esta relação como a essência do fenômeno da transferência. Von Franz ainda assinala que o efeito redutor da terapia em grupo, no que diz respeito à transferência, é claramente prejudicial, pois facilita o afastamento do analista frente a uma possível transferência poderosa.

Samuels (1989), ao se referir às modalidades diferentes de aplicação da Psicologia Analítica, afirma que esta tem sido aplicada na terapia de grupo, enfatizando que "a teoria de Jung sobre o self como continente e regulador de todas as partes díspares da personalidade é aplicável à psicologia de grupo, e a base arquetípica do processo e dos temas de grupo tem sido elaborada (por exemplo, Hobson, 1959; Whitmont, 1964; Fiumara, 1976; Jung. Eb., 1983)" (p. 243).

Esse mesmo autor, ao discutir o conceito de individuação para Jung e para os pós-junguianos, como Hillman e Fordham, enfatiza que é preciso ligar a individuação ao funcionamento grupal e social, e afirma não ver motivo teórico para que os elementos centrais da individuação, principalmente após a reformulação feita pelos pós-junguianos, não sejam aplicados à vida social.

Freitas também refletindo sobre a posição de Jung em relação aos trabalhos com grupos afirma.

No entanto, parece difícil compreender tal recusa [de Jung em trabalhar com grupos] num autor que enfatizou tanto a totalidade quanto a multiplicidade da vivência psíquica, a importância da interação entre polaridades e propôs, como pilares, os conceitos de processo de individuação e de inconsciente coletivo. De alguma maneira, o individual e o coletivo encontram-se estabelecidos em seu referencial teórico e, parece-nos que, embora a individuação implique a ampliação e constante estruturação dinâmica da consciência, o indivíduo não é sinônimo de ou equivalente à consciência, e tampouco coletividade corresponde a inconsciente. (Freitas, 2005, p. 51) 
Podemos também lembrar a importante afirmação de Jung (1971/1981) a respeito do processo de individuação e de como o desenvolvimento psicológico do indivíduo está atrelado às suas relações com os demais seres humanos: "A individuação é 'tornar-se um' consigo mesmo, e ao mesmo tempo com a humanidade toda, em que também nos incluímos" (par. 227) [grifos do autor].

Neumann (1991), ao diferenciar grupo e massa, assinala que no início da humanidade, objetivos comuns favoreciam a formação dos grupos e esta formação era condição essencial para o desenvolvimento da consciência. A racionalidade extremada e, portanto, o desenvolvimento unilateral do ser humano acarretou a ausência de vinculação afetiva entre as pessoas e, conseqüentemente, a dissolução do processo grupal. Daí o surgimento das massas, que, para Neumann (1991), não passa de "uma agregação de indivíduos que não estão vinculados emocionalmente, entre os quais não ocorre nenhum processo inconsciente de projeção" (p. 296). No grupo, os membros estão emocionalmente ligados uns aos outros, sendo sua formação decorrente da existência de participation mystique entre esses e de processos inconscientes de projeção. Os laços inconscientes entre os membros de um grupo asseguram também o caráter permanente deste, e esta condição de permanência lhe confere caráter histórico.

Hillman (citado por Samuels, 1989) aponta que o processo de individuação, para alguns, gera limitações nos relacionamentos interpessoais, mas, para outros, ao contrário, essas relações afetivas são essenciais para que esse processo de integração se desenvolva a contento.

Ainda a respeito da viabilidade de se trabalhar com grupos e o processo de individuação, Samuels afirma.

Agora precisamos ligar a individuação ao funcionamento grupal e social. Muitos junguianos "não sabem lidar com grupos" (ou dizem isso) [...] Não imagino nenhuma razão teórica segundo a qual os elementos centrais da individuação, sobretudo de como foram modificados e reconstruídos pelos pós-junguianos, não possam ser aplicados à vida social em geral. (Samuels, 1989, p. 140) [grifos do autor]

A psicoterapia grupal, neste sentido, pode atender a essas questões umavez que, paralelamente ao processo interior de integração das partes da personalidade, há condições, dentro do grupo, de desenvolvimento em direção a um desenvolvimento do self grupal. 
[...] se destacam dois pontos fundamentais para trabalhar com o grupo com a psicologia do Self: a) a importância de um Self grupal; b) a relação Self individual versus Self grupal, [...] A idéia central pela qual o grupo se reúne é que designa o Self grupal, que inclui um fator temporal "duradouro" podendo vir a mudar na medida em que o grupo muda sua personalidade. (Alt, 2000, p. 155) [grifos da autora]

Freitas (2005), analista junguiana e docente do Instituto de Psicologia da USP, no seu trabalho com grupos vivenciais sob uma perspectiva junguiana, refere que o grupo define uma totalidade considerada por essa autora como self grupal e este seria uma ampliação do conceito de self individual.

Whitmont (citado por Freitas, 2005) afirma que a exploração do inconsciente, numa situação de psicoterapia grupal, é tão importante quanto analisá-lo por meio de recursos introspectivos direcionados aos processos oníricos ou imaginação ativa. Esse autor menciona as vantagens na "análise num setting grupal": o sentimento por parte do membro do grupo de pertencer a algo maior, experienciando tanto seus aspectos singulares como comuns ao grupo, a condição de se sentir apoiado e se auto-apoiar, de lidar com pessoas com características de personalidade diferentes e visões diversas, a possibilidade de um trabalho mais amplo com os conteúdos projetados e de desenvolvimento de relações afetivas mais autênticas. Todas essas condições possibilitam que o arquétipo do grupo possa ser "vivenciado tanto na dimensão que envolve sentir-se pertencendo, quanto na que implica valores e leis" (p. 51).

Freitas (2005), baseando-se em outro trabalho de Whitmont (1991), acrescenta que, para esse autor, num trabalho grupal, a experiência vivida tem que ser valorizada, mais do que os preceitos pré-estabelecidos, assim como a retirada das projeções e a consideração pelo enfoque do outro. Os sentimentos de acolhimento e "uma exploração lúdica sustentada por uma atitude de permanente busca, na qual a espontaneidade e a auto-disciplina coexistam, numa constante auto-descoberta e aperfeiçoamento de relacionamentos baseados em confiança e aceitação mútuas, tanto individual quanto coletivamente" (p. 52) são aspectos significativos no trabalho grupal.

A relação humanizada construída durante a psicoterapia grupal faz com que as mais diferentes experiências emocionais, positivas ou não, não necessitem ser 
atuadas, mas possam ser meditadas, e que manifestações do arquétipo sombra sejam percebidas de forma construtiva, levando-se em conta seu potencial transformador. A aceitação de como se é e a busca de inclusão e integração de todo tipo de característica pessoal, desejável ou não, como parte da própria realidade psíquica possibilitam que a vivência grupal se torne fonte de crescimento pessoal e de desenvolvimento das relações sociais.

Nessa mesma obra, Whitmont discorre sobre os elementos importantes que fazem parte dos rituais e que são fundamentais para sua eficácia. Freitas (2005) os relaciona e assinala que, no trabalho grupal, predomina o "deslocamento do foco do ego para o self e para a relação com o outro e com o grupo" (p. 52).

Zinkin (1998), analista junguiano e com formação em análise de grupo, destaca-se por valorizar o trabalho grupal e ver neste tipo de intervenção condições para o desenvolvimento do processo de individuação.

A tarefa da individuação não é apenas garantir a própria individualidade contra uma multidão que ameaça destruí-la, mas perceber que ninguém vive isolado e que a vida não tem sentido por si só. Seu significado deriva da coletividade, da qual cada um é parte, e Jung, ao propor o centro da personalidade como o self, que é muito maior do que o ego, enfatiza a dimensão coletiva. (Freitas, 2005, p. 55) [grifo da autora]

Zinkin (1998) percebe o indivíduo integrado ao coletivo e, a partir dessa percepção, desenvolveu o conceito de inconsciente cultural. Esse autor enfatiza o papel da cultura, e põe em relevo a função primordial dos arquétipos, que dependem das interações sociais para adquirirem forma e facilitar a interação e os contatos com os demais seres humanos. Dessa forma, a teoria de psicoterapia grupal desenvolvida por Zinkin, está centrada na idéia de interação: as relações afetivas no início da nossa vida vão modular todas as demais relações, as relações intrapsíquicas dependem das relações interpessoais, e dessas relações, desenvolvidas no âmbito da terapia individual ou grupal, vão decorrer também a forma como o indivíduo se vê na análise.

Ao contrário de Jung, que preconizava que o grupo exercia efeito limitante para o processo de individuação do indivíduo, Zinkin concebe a influência do grupo como favorável para este desenvolvimento. 
Zinkin, baseado em Bion, diferentemente de Zimerman (2000), considera o grupo como continente e conteúdo, assinalando que, se, de início é o terapeuta quem propicia a continência grupal, através do enquadre e das condições de acolhimento e segurança de que o grupo necessita. Com o decorrer da terapia, o próprio grupo vai promovendo a condição continente, e com as transformações que se operam em cada membro do grupo, novas transformações no grupo vão se processando, sempre de forma que integração e continência vão se interligando e se construindo.

Nesse sentido, esse autor assinala que continente e conteúdo estão sempre interagindo, em constante movimento visando ao equilíbrio.

Freitas (2005), ao refletir sobre a teoria de Zinkin diz que "quando os participantes falam do 'grupo', instaura-se uma ambigüidade e não se sabe mais se eles são o grupo, os conteúdos do grupo ou o continente do grupo" (p.56). Essa situação ambígua, em que se depara com a impossibilidade de diferenciar indivíduo e continente, tem aspectos positivos pois favorece transformações $\mathrm{e}$ conscientização. A interação, que se desenvolve e que caracteriza o processo analítico grupal, vai então além da relação intrapsíquica e do diálogo da consciência com o inconsciente, abarcando as relações interpessoais que contemplam o confronto de visões diferentes.

Assim, o diálogo é concebido como princípio conciliador e a relação mostra que há dois sujeitos, em interação, e o senso de self de cada um é favorecido precisamente por sua incompletude sem o outro. O sujeito é descentrado, mas não eliminado. Aceitação mútua não significa concordância, mas aceitação das diferenças, e a partir dela cada um poderá afirmar e confirmar o outro, e ambos beneficiam-se com a troca. (Freitas, 2005, p. 56) [grifos da autora]

No seu trabalho, Freitas estabelece relações entre Héstia, deusa grega que enfatiza a interioridade e o anonimato, e a experiência dos grupos vivenciais. Diz a autora que Héstia está relacionada à focalização e ao acolhimento que aquece, protege e gera confiança. Dessa forma, essas características existentes no campo psicológico, criado nos grupos vivenciais, transcendem as condições inerentes a uma simples reunião de pessoas, e o transformam em "um campo simbólico constelado que acolhe e conduz ao conceito de self grupal' (p. 58) [ grifos da 
autora] em que forças dinâmicas de separação e coesão atuam, se harmonizam e geram vitalidade.

Freitas também chama atenção para as características do local onde o grupo se reúne, apontando-o como também uma força estruturante no grupo, e que traz em sua essência a possibilidade de que o que é físico se transforme em psíquico.

Ainda relacionando a deusa Héstia com a experiência grupal, Freitas (2005) faz considerações sobre as possibilidades que um espaço centralizado contém.

[...] O centro que nos oferece é aquele que organiza um espaço, redondo, simultaneamente centrífugo e centrípeto, de onde se irradiam luz e calor e todo um campo simbólico pode ser definido, dando continência a aspectos diferentes que, em outros contextos, poderiam ser contraditórios ou mesmo patológicos. (Freitas, 2005, p. 59)

A autora acrescenta que as condições de monotonia e de repetição próprias do desenvolvimento das sessões têm também efeito estruturante, na medida em que fornecem uma base sólida e segura, e dão condições para que haja rebaixamento das funções da consciência e com isto imagens do inconsciente possam mais facilmente emergir.

A respeito do uso de recursos expressivos durante o trabalho grupal, Freitas considera que através de diferentes formas - desenho, modelagem, palavras, gestualidade - os símbolos podem se apresentar à consciência.

A utilização de recursos expressivos tem-se mostrado de grande valia para a emergência de imagens numa forma mais precisa e contextualizada, Desde que não se façam consignas muito restritivas, há uma exploração espontânea do recurso e do material, que favorece a definição do que está pronto para ser trabalhado e ocupar o lugar de "figura" para a consciência, e do que servirá como "fundo", num dinâmico processo de focalização, a cada momento ou etapa do processo de self grupal. (Freitas, 2005, p. 60) [grifos da autora]

A autora discorre ainda sobre a importância da vivência da crise, salientando o fato de esta conter a exigência de mudança de focalização, o que pode propiciar ampliação da consciência.

A respeito do papel do coordenador do grupo, Freitas (2005) o concebe como aquele que é responsável pela "manutenção de um campo fértil para a vivência do 
self grupal" (p. 61) [grifos da autora], sabendo aguardar a manifestação do inconsciente e como focalizá-lo. Cabe também ao coordenador cuidados relativos quanto à sua conduta, evitando atitudes racionais e explicativas que podem desvitalizar e dissecar a experiência vivida, bem como reações movidas essencialmente pelas forças inconscientes, o que pode afetar sua função básica de assegurar a centralidade e objetividade do trabalho.

O coordenador deve também cuidar para que a estabilidade e a coerência prevaleçam, mantendo-se atento e dedicando-se ao máximo para que o trabalho grupal se desenvolva da melhor forma possível.

Freitas (2005) assim sintetiza as funções do coordenador.

[...] cuida das condições para a criação e manutenção de um campo simbólico, acolhe e protege o que ali se apresenta, mais do que dirige, opina ou procura viver relacionamentos humanos. Ele, paradoxalmente, é quase ninguém e tem uma presença fundamental, ao possibilitar o espaço para a experiência psicológica se dar, para as imagens se apresentarem e serem focalizadas. (Freitas, 2005, p. 63)

O self grupal, diz Freitas, essencialmente representa o porto seguro, a base que serve de sustentação para que as trocas realizadas no mundo externo sejam compartilhadas e para a focalização, o acolhimento e a expressão das imagens significativas. Esse compartilhar é fundamental e as diferentes reações por parte dos membros do grupo, integradas às demais situações vividas, constroem a história do grupo e o acervo do self grupal.

Freitas (2005) sintetiza suas idéias a respeito do trabalho grupal assinalando que o acolhimento, a afetividade, a solidariedade, a convivência e a empatia, enfim, a construção de um self relacional assegura o sentido de unidade e integração, condições estas essenciais para que os conteúdos inconscientes, que devem vir à consciência, possam emergir através de imagens ou de outros meios, e que a experiência psicológica se desenvolva.

Oliveira (2006), arte-terapeuta de orientação junguiana, em sua dissertação de mestrado, relatou uma experiência com processos grupais, com mulheres, utilizando uma abordagem imagético-apresentativa. Nesse trabalho, a autora reflete sobre o papel da materialidade como intermediadora de um diálogo dessas mulheres com partes desconhecidas de si mesmas e, também, com o grupo. A materialidade 
nesse grupo terapêutico-vivencial ocupava o ponto central que unificava as idéias e as emoções das participantes, não sendo utilizada como recurso expressivo que exige uma postura interpretativa, mas como um trabalho imagético com as imagens psíquicas dentro do grupo. Na conclusão do trabalho, a autora relata ter observado transformações positivas no grupo indicando que o trabalho, inicialmente considerado como um processo de arteterapia, "se encaminhou para uma experiência de psicoterapia de grupo com resultados objetivos para a maioria das participantes" (p. 102).

A respeito do trabalho grupal especificamente com idosos, Amado (2004), especialista em psicoterapia analítica de grupo (membro do IAGP), considera que para a população idosa esse tipo de intervenção pode ser de grande ajuda, pois o idoso, em função das inúmeras perdas, "teria necessidade de um narcisismo suficientemente forte para atravessar este período sem cair na depressão" (pp. 8487), e tendência a comportamentos regressivos, visando suprir sua necessidade de proteção e cuidados. Para aqueles idosos cujo narcisismo e mecanismos regressivos estivessem alterados, a terapia grupal seria especialmente eficaz.

Amado complementa assinalando que o trabalho grupal possibilita que os idosos interajam de uma "forma menos egoísta e defensiva como geralmente acontece. Também contribui para o desenvolvimento da socialização o fato de se sentiram compreendidos um pelo outro em razão de compartilharem uma mesma linguagem, o que facilita o processo de comunicação" (pp. 84-87).

A relação com o grupo é, de maneira geral, muito eficaz e terapêutica, principalmente para aqueles idosos que têm como queixa a solidão.

Essa autora ainda aponta um outro ponto positivo do trabalho grupal: a função de espelho, através da qual o idoso, a partir do grupo, pode desenvolver a "capacidade de reconhecer a si próprio, de reconhecer o outro e, mais ainda, de reconhecer-se através do outro" (pp. 84-87).

Assim, aquele narcisismo do idoso, somente preocupado com a sua vida, pode melhor ser trabalhado e entendido num grupo [...]. É devido a este narcisismo que, na terapia de grupo com idosos, a matriz grupal demora a se estabelecer. [...] Resumindo, seria quando todos os indivíduos que fazem parte do grupo passam a se interessar por um assunto em comum: a terapia deixa de ser de vários indivíduos no grupo para ser uma terapia de grupo. (Amado, 2004, pp. 86-87) 
Para essa autora (2004), o grupo favorece que o esquecido seja re-lembrado e que o idoso supra sua necessidade de ser reconhecido pelos outros. De acordo com a sua experiência, a terapia grupal não deve basear-se em interpretações, mas deve procurar "reassegurar a confiança, proporcionar abertura, ajudar a operacionalizar mudanças" (p. 87).

1.2. Fundamentos Teóricos para uma Psicoterapia Grupal Breve de Orientação Junguiana

\subsubsection{A crise como Possibilidade de Crescimento}

De modo geral, a busca por um tratamento psicoterápico decorre de uma vivência de crise, seja ela causada por fatores externos ou internos.

A palavra crise tem raízes no grego e contém em sua essência tanto o perigo e a derrocada, como a possibilidade de transformação e crescimento.

A energia psíquica dispendida numa situação de crise mobiliza um arquétipo e esta mobilização atua sobre a consciência de formas diversas: se a consciência tiver condições de compreender e de integrar os conteúdos inconscientes ativados, esse arquétipo agirá no sentido de uma reorganização positiva da psique, caso contrário, pode haver um desequilíbrio psíquico.

Crise pode ser definida como sendo um desequilíbrio no processo energético da psique. A energia psíquica migra, se transforma e retira-se para o inconsciente, reaparecendo sob forma de sintoma (denúncia de que há um desequilíbrio no processo energético). (Biagioni, 2005, p. 13)

Aqui podemos também relacionar crise e a forma como Jung concebe os problemas.

Os problemas, portanto, nos compelem a um estado de soledade e de orfandade absoluta, onde nos sentimos abandonados inclusive pela natureza e onde somos obrigados a tornar-nos conscientes. Não temos outra via de saída, e somos forçados a substituir nossa 
confiança nos acontecimentos naturais por decisões e soluções conscientes. Cada problema, portanto, implica a possibilidade de ampliar a consciência, mas também a necessidade de nos desprendermos de qualquer traço de infantilismo e de confiança inconsciente em a natureza.(Jung, 1971/1984, par. 751)

Vemos, então, que as crises, como os problemas, se confrontados, contêm em si as possibilidades de crescimento.

Biagioni (2005) acrescenta que a crise, como forma de o inconsciente sinalizar a necessidade de transformação, pode ser do tipo evolutiva, que se caracterizaria por ser previsível e fazer parte dos ciclos da vida, e do tipo acidental, imprevisível e muitas vezes decorrente de influências externas. As situações de crise podem se caracterizar por "agudização de uma situação psicológica, desorganização da identidade, falta de recursos diante de uma situação nova e ausência de perspectiva" (p. 13).

Durante a crise, o funcionamento egóico falha na captação dos conteúdos inconscientes, daí a importância de se iniciar a Psicoterapia Breve ainda no começo da crise e intervir através de uma ação suportiva.

O sintoma surge a partir de uma situação de desequilíbrio no processo energético da psique e vai sinalizar qual o foco que pode ser trabalhado numa Psicoterapia Breve.

\subsubsection{O Foco}

O foco é o "tema dominante", o ponto central das dificuldades psicológicas do cliente, e a partir da sua delimitação o psicoterapeuta vai selecionar quais técnicas podem ser utilizadas para lidar com o que está bloqueando a "ação transformadora". Nas palavras de Biagioni (2005), "o foco é o cerne do problema psicológico sobre o qual psicoterapeuta e cliente deterão a atenção para o desenvolvimento do tratamento psicoterapêutico" (p. 13). Essa autora assinala a diferença operacional entre a noção tradicional de "foco" (reforço das associações e insights do cliente em direção ao foco) e o trabalho analítico com ele através da mobilização do potencial criativo do cliente.

As contribuições de Malan devem aqui ser relembradas. 
Pode-se formular o objetivo limitado em termos de um efeito terapêutico desejado, mas, uma vez serem os efeitos terapêuticos difíceis de prever, provavelmente seja melhor formular o objetivo em termos de uma área específica que necessite ser trabalhada e, desta maneira, um tema específico para interpretações. Como estas dependem do material que o paciente traz, surge a necessidade de uma forma mais tática de "atividade", ou seja, de orientar o paciente durante as consultas por meio de interpretações seletivas, atenção seletiva e negligência seletiva. (Malan, 1981, p. 44) [grifos do autor]

A interpretação seletiva implica que não é qualquer conteúdo que deve ser interpretado, mas apenas aqueles que estão relacionados com o foco. A atenção seletiva, por parte do terapeuta, visa fazer com que este não perca de vista o tema dominante e os conteúdos relacionados a ele, e esse tipo de atenção impõe a capacidade de o terapeuta negligenciar assuntos que, embora sejam importantes para o cliente, possam acarretar desvio do foco e causar dispersão.

Quando afirmamos que psicoterapeuta e cliente, num trabalho breve, devem focar a atenção sobre um determinado tema dominante, que está bloqueando o fluxo energético e impedindo que processos criativos se desenvolvam, não queremos afirmar que esta focalização deve ser rígida. A atenção do psicoterapeuta tem que ser seletiva, para que não se perca o foco, mas pode contemplar algumas mudanças em função de novos eventos que surjam durante o processo e que precisam também ser abordados e relacionados ao tema dominante.

\subsubsection{A Importância do Diagnóstico}

Mas a delimitação do foco não é um trabalho simples, é preciso que uma visão diagnóstica da personalidade do cliente nos ajude a identificar os complexos que estão atuando e os recursos internos disponíveis para que uma intervenção breve seja bem- sucedida.

Os mais importantes teóricos sobre Psicoterapia Breve, como já foi mencionado no capítulo 4, assinalam que independentemente das técnicas utilizadas - entrevistas clínicas, testes psicológicos, observações do comportamento - a fase de diagnóstico é fundamental. A realização de entrevistas diagnósticas, com 
o levantamento de toda a história de vida do cliente, e, quando necessário, o uso de técnicas projetivas, podem favorecer uma análise profunda da psicodinâmica do cliente, revelando seus recursos egóicos, e indicar quais procedimentos e técnicas podem ser mais eficazes para o desenvolvimento do processo psicoterapêutico.

Biagioni (2005) aponta que essa avaliação também possibilita que se observe como o cliente se adapta à crise que vivencia e se identifique o nível de fragilização egóica.

Na Psicologia Analítica, o diagnóstico é um procedimento importante, mas sua ênfase é no indivíduo como um todo, evitando uma visão classificatória e/ou estigmatizada.

Os diagnósticos clínicos são importantes pelo fato de proporcionarem uma certa orientação, embora não ajudem o paciente. O ponto decisivo é a questão da "história" do doente, pois revela o fundo humano, o sofrimento humano e somente aí pode intervir a terapia do médico. (Jung, 1961/1988, p. 115) [ grifo do autor]

As entrevistas, quando realizadas pelo próprio psicoterapeuta ativam arquétipos que comportam idéias sobre a imagem de si mesmo e do psicoterapeuta.

[...] é preciso levar em conta que, já no primeiro contato, e mesmo antes dele, os arquétipos atuam com intensidade na dinâmica do psiquismo do paciente, entendendo-se por arquétipos, no caso, as imagens que este tem de si próprio e do terapeuta, de acordo com modelos universais e eternamente operantes. (Caracushansky, 1990, p. 158)

Assim como mobilizamos os arquétipos nos clientes, estes também ativam em nós imagens que podem nos elucidar a respeito dos sentimentos despertados por eles, e esclarecer aspectos do seu funcionamento psíquico.

Biagioni (2005) recomenda também a avaliação tipológica como meio de "verificação do movimento energético, de acordo com o tipo de problema emocional (eixo Ego-Self)" (pp. 14-15).

Essa autora complementa:

A avaliação tipológica permite a identificação das funções psicológicas, (as funções de adaptação: função superior e a primeira função auxiliar), que representam as funções do ego com o meio, através da Persona. Essas são as funções que precisam ser 
integradas em situação de crise e constituirão o apoio às forças do ego. São as funções mais utilizadas na Psicoterapia Breve. A segunda função auxiliar e a função inferior representam os potenciais de desenvolvimento da pessoa, principalmente na segunda metade da vida, com vistas à individuação. (Biagioni, 2005, p.15) [grifos da autora]

A respeito dos tipos e funções psíquicas nos diferentes ciclos da vida, Jacobi (1976) afirma que, segundo Jung,

a tarefa principal da juventude é a diferenciação e isolamento daquela função que, disposicionalmente, capacita de modo mais seguro para lidar e superar as dificuldades do mundo externo. [...] Porque, a não ser que seja necessário, o indivíduo não pode nem deve empreender o caminho do inconsciente antes de ter cimentado firmemente sua consciência da realidade [...]. O mesmo ocorre com o tipo de atitude [...]. Só a segunda metade da vida traz a missão de conceder a palavra ao tipo de atitude oposta. (Jacobi, 1976, p. 53)

Como aponta Biagioni, observa-se que na crise a função inferior catalisa energia psíquica das demais funções, inclusive da função superior - mais diferenciada e responsável pela adaptação - e acarreta desequilíbrio psíquico. Daí a necessidade, durante a Psicoterapia Breve, de se utilizar o reforço egóico e se trabalhar no sentido da integração das funções responsáveis pelos processos adaptativos.

Nesta pesquisa, visando à Psicoterapia Grupal Breve com adultos idosos, o foco deve ser direcionado para a auto-realização e o desenvolvimento de potencialidades individuais, a partir do fortalecimento das funções mais diferenciadas e responsáveis pela adaptação. Na velhice, a elaboração das diferentes perdas - os papéis sociais, o vigor da juventude, a saída dos filhos, a morte dos pais ou pessoas significativas, a aposentadoria, a menopausa e andropausa e as mudanças na vivência da sexualidade - torna-se muitas vezes difícil, acumulando-se lutos e sofrimento psíquicos.

É importante também ressaltar que num processo grupal breve, o foco pode ser um tema que represente uma dificuldade comum a todos os participantes do grupo, e a identificação desse foco pode ser obtida a partir do diagnóstico. 


\subsubsection{O Planejamento e a Técnica do Processo da Psicoterapia Breve}

Na Psicoterapia Breve, segundo Melo (1998) e Biagioni (2005), visa-se ao reforçamento egóico e, através deste, que o ego funcione de forma mais flexível frente às imagens do inconsciente e possa integrá-las.

De acordo com Biagioni (2005), o planejamento deve priorizar o ego, o ponto de convergência deve ser as funções adaptativas, e o objetivo do processo psicoterápico é a integração das funções psicológicas, essa integração resultando na resolução da crise ou alívio do sintoma.

A mobilização do processo criativo do indivíduo facilita a agilização e focalização da psicoterapia, ampliando o campo da consciência e assim, favorecendo o fortalecimento do ego, deixando-o mais apto à integração de imagens anteriormente dissociadas. (Melo, 1998, p. 22)

Algumas características são consideradas básicas do processo psicoterápico breve: não visa favorecer a regressão, o psicoterapeuta intervém de forma ativa e imediata, os objetivos são colocados conjuntamente pelo psicoterapeuta e cliente e são limitados, não visa atingir níveis profundos da personalidade como num processo analítico, o tema dominante, identificado a partir do diagnóstico, indica o foco a ser trabalhado e o tempo do processo é limitado.

Segundo Biagioni (2005), "De modo geral, o planejamento deve contemplar: diagnóstico, estratégias de trabalho, objetivos a serem alcançados e o foco [...]" (p. 15).

A colocação do enquadre envolve aspectos importantes e singulares como o fato de, desde o início do tratamento, o cliente ter noção do seu término. Esse conhecimento opera no sentido de o cliente, ao mesmo tempo em que desenvolve o vínculo com o psicoterapeuta, já se prepara para o fechamento da relação. A complexidade contida nesse tipo de relação terapêutica exige que o cliente tenha força egóica suficiente para lidar com essa condição de vinculação e separação.

A escolha de um foco, a partir do tema dominante trazido pela queixa, e a capacidade de manter-se centrado neste foco implicam também recursos internos 
quanto à capacidade do ego para lidar com a frustração (de não abordar outros temas).

A relação psicoterapeuta-cliente na Psicoterapia Breve assume algumas características próprias. Assim como na psicoterapia individual, sob o enfoque da Psicologia Analítica, a relação psicoterapeuta-cliente é uma relação de igualdade, em que ambos crescem, embora, por ser um processo de tempo limitado, caiba ao psicoterapeuta manter maior objetividade em função dos objetivos desse tipo de intervenção.

Quando a Psicoterapia Breve envolve poucas sessões, a transferência e a contratransferência não são trabalhadas diretamente. Nesses casos, a atuação do psicoterapeuta baseia-se mais no incentivo a que o paciente tenha maior autonomia e seja mais responsável por si mesmo.

Sobre a ativação do arquétipo do curador-ferido, Melo afirma

O arquétipo constela a bipolaridade e sendo assim, na relação terapeuta-paciente, essa imagem arquetípica está presente no terapeuta e no cliente. Necessário é a mobilização do curador interno do paciente projetado inicialmente no terapeuta que precisa também projetar a sua ferida interna no paciente. É dessa forma, que pode mobilizar o curador interno dele. Na Psicoterapia Breve, a importância dessa mobilização é grande assim como em qualquer processo analítico. A empatia pelo paciente dá ao terapeuta 0 conhecimento do que é ser paciente, uma vez que ele próprio também tem ferida. As qualidades pessoais do terapeuta devem ser mobilizadas para a realização do processo, caracterizando a forma como vai ser desenvolvido o trabalho, desde a primeira entrevista. (Melo, 1998, p. 25)

Biagioni (2005) ressalta também que o planejamento deve levar em conta "os recursos pessoais do psicoterapeuta (técnicos e práticos), recursos da instituição ou local onde o processo ocorrerá (tempo, espaço, motivação, apoio técnico, apoio humano) e recursos pessoais do cliente - motivação" (p. 15).

Em relação ao número de sessões num processo psicoterápico breve, essa autora sugere formas variadas de contratos terapêuticos que visem a um foco mais superficial ou mais profundo: desde Terapia de Apoio, com seis a oito sessões, até Psicoterapias Breves com foco mais profundo, com cerca de 100 sessões. O contrato pode ser feito por número de sessões ou por tempo determinado.

O símbolo, como ponte entre consciente e inconsciente, e como "máquina transformadora de energia psíquica", tem um papel importante na estruturação da 
consciência e na conexão desta com o inconsciente, e vários recursos, verbais ou não-verbais, podem ser utilizados, durante o processo psicoterápico breve, para facilitar a sua manifestação. Entre os diversos recursos, podemos citar, inicialmente, os recursos verbais, como o trabalho com os mitos e contos de fadas, que, por meio da amplificação, possibilitam a unificação consciente-inconsciente, a análise dos sonhos e das fantasias e a interpretação dos conteúdos trazidos pelo cliente.

A respeito das interpretações na Psicoterapia Breve, Caracushansky (1990) relaciona alguns procedimentos técnicos que podem ser utilizados e facilitar as interpretações: a) Confrontação: mostrar para o cliente como está sendo o seu comportamento, confrontando-o com a realidade. A eficácia desta técnica depende da existência de bons recursos egóicos; b) Explanação: pode ser desenvolvida através do esclarecimento propriamente dito e da informação. No primeiro caso, as funções cognitivas são muito exigidas no sentido de o terapeuta esclarecer como as dificuldades emocionais estão afetando a vida do cliente, e, no segundo caso, o terapeuta, quando avalia que há falta ou falhas de informação, ele as fornece estimulando uma possível transformação, mesmo que seja por meio da intelectualização. Nesse ponto, a autora refere que, dependendo da gravidade do caso, é preferível uma defesa como a intelectualização, do que defesas desestruturantes; c) Ilustração: o uso de histórias para facilitar o insight.

Além dos recursos verbais expostos acima, outros como a pintura, o desenho, a argila, o Jogo da Caixa de Areia, e técnicas que envolvem trabalho corporal podem ser utilizados.

$\mathrm{Na}$ Psicoterapia Grupal Breve, alguns cuidados devem ser tomados na escolha e na análise desses recursos, na medida em que características, tais como, tipo de relação terapêutica (psicoterapeuta-grupo e membros do grupo entre si), objetivos e limite temporal do tratamento podem dificultar uma abordagem estritamente interpretativa. Parece-nos que um enfoque imagético, que mobilize as emoções frente às imagens provenientes do inconsciente, via sonhos ou expressões gráficas ou trabalho corporal, pode surtir efeitos mais satisfatórios.

Jung (1971/1981) aponta a existência de algumas etapas no desenvolvimento do processo psicoterápico: 1. A Confissão: momento inicial em que o cliente consegue desabafar, contar seu segredo, deixando vir à consciência conteúdos inconscientes causadores de conflitos intrapsíquicos; 2. A Elucidação: após a catarse, o cliente se sente vinculado ao psicoterapeuta e mecanismos projetivos e 
transferenciais se desenvolvem intensamente. É um momento de aprofundamento do processo e o uso de recursos que facilitem a emergência de conteúdos inconscientes é de grande valia; 3. A Educação: após os dois primeiros passos, o cliente percebe que é preciso abrir novos caminhos, e que isso só é possível se houver vontade de se educar; 4. A Transformação: engloba a análise e a síntese. Nesse momento há a dissolução dos complexos e a retirada das projeções, e, posteriormente, a síntese de uma entidade adaptada e enraizada na própria individualidade, ou seja, no si mesmo.

Quanto às indicações para uma Psicoterapia Breve, a maioria dos teóricos aponta: 1. uma estrutura egóica relativamente preservada; 2 . capacidade de falar e ouvir, isto é, ter as "funções autônomas" do ego preservadas; 3. ter uma história biopsicosocial que revele condições de enfrentamento e superação de situações de crise; 4. ter experienciado relacionamento afetivo confiável; 5. capacidade de manifestação emocional; 6. capacidade de se vincular, de alguma forma, com o terapeuta; 7. capacidade de se perceber numa situação de crise ou, pelo menos, permitir que o psicoterapeuta ajude nessa compreensão; 8. demonstrar estar motivado, em algum nível, para a psicoterapia; 9. disponibilizar algum tempo para o tratamento; 10. aceitar as condições do enquadre.

Os processos breves são mais indicados em situações de crise, pois o que se observa nesses momentos, é um movimento energético em busca da compensação. O aparecimento do sintoma é o quadro que tenta compensar o que se passa no inconsciente, que invade o ego e move-se contra ele mesmo. A queixa refere-se ao incômodo do cliente, o que impossibilita uma vivência satisfatória. (Biagioni, 2005, p. 18)

Em relação às contra-indicações, a maioria dos autores enfatiza que patologias que prejudiquem ou impeçam a capacidade de estabelecer vínculos afetivos tornam o cliente impossibilitado de participar de uma Psicoterapia Breve. No caso de clientes idosos, indícios de quadro demencial podem comprometer o tratamento e, neste sentido, contra-indicam o mesmo.

Com a proximidade do fim do tratamento, o psicoterapeuta deve, nas últimas sessões, ir "fechando" gradativamente com o cliente os pontos que foram trabalhados durante o processo, relacionando-os à queixa inicial, ao fator que 
desencadeou o sofrimento psíquico e ao foco que foi estabelecido, sinalizando os ganhos e as possibilidades de mudança.

A entrevista ou sessão de acompanhamento, ou Follow up, é a última etapa do processo de Psicoterapia Breve. Esta geralmente é realizada após o término dos atendimentos, cerca de 90 dias após a última sessão.

Seu objetivo é, portanto, avaliar como o cliente está após a finalização do processo, levando-se em conta critérios como: se as dificuldades apontadas inicialmente foram superadas, se o objetivo escolhido foi atingido, total ou parcialmente, se o processo foi direcionado adequadamente em direção ao foco, se os critérios para observação foram satisfatórios, quais mudanças aconteceram, se as transformações ocorreram de forma concreta, em forma de ação.

A respeito da busca da individuação através da Psicoterapia Breve, Biagioni retoma as idéias de Jung.

Percebendo o mal que um enquadramento rígido poderia fazer ao desenvolvimento individual de uma pessoa, Jung não preconiza nenhuma receita para a individuação. Para ele, cada indivíduo é sempre único. Assim também é único o caminho de cada um para a resolução de seus conflitos. (Biagioni, 2005, p. 20)

Daí que o processo de Psicoterapia Breve de orientação junguiana aqui exposto, embora tenha um eixo teórico que lhe dê sustentação e consistência, não é um processo fechado e cristalizado, mas sim um tipo de intervenção que, em sua essência, não visa à cura definitiva, nem à análise profunda dos processos inconscientes, mas objetiva minorar o sofrimento psíquico através do fortalecimento egóico e do equilíbrio da atitude psicológica.

Especialmente no caso da Psicoterapia Grupal Breve, conjuntamente com esses objetivos acima mencionados, temos também a meta, como diz Freitas, de construir um self relacional, e através desta construção desenvolver um self grupal que favoreça o crescimento psicológico. 


\section{CAPÍTULO VI}

\section{OBJETIVOS}

O objetivo geral deste trabalho é propor uma nova modalidade de aplicação da Psicologia Analítica - a Psicoterapia Grupal Breve com idosos - e verificar os seus benefícios.

Objetivos específicos: a) ilustrar o uso de recursos expressivos (no caso, desenhos) e sonhos em Psicoterapia Grupal Breve; b) apresentar uma análise crítica dos instrumentos utilizados individualmente (Método de Rorschach e entrevistas) e de forma grupal (observação) para avaliação da evolução tanto de cada participante idoso como do grupo. 


\section{CAPÍTULO VII}

\section{MÉTODO}

\subsection{Participantes}

Esta pesquisa foi realizada com estudantes de uma Universidade da Terceira Idade de uma instituição do Grande ABC, sem histórico de doenças incapacitantes e de doenças psiquiátricas graves. Participaram deste estudo sete idosos - seis mulheres e um homem - com idade entre 60 e 70 anos. A escolha dessa faixa etária relaciona-se com o interesse pelo estudo dos psicodinamismos característicos do início da velhice, considerado pela maioria dos autores, a partir dos 63/65 anos.

\subsection{Procedimento: Fases e instrumentos}

A coordenação da instituição foi contatada por mim e o projeto da pesquisa, de forma sintética, foi apresentado ao coordenador para que este pudesse ter ciência dos objetivos e procedimentos do trabalho e desse autorização para a sua execução.

A partir da aprovação do projeto, os alunos de duas classes foram convidados a participar da pesquisa. O convite foi feito pessoalmente por mim, e foram fornecidas informações básicas sobre objetivo, duração da pesquisa, faixa etária dos integrantes e local.

Dez participantes se inscreveram.

Fases da pesquisa: 


\subsection{1. $1^{\text {a }}$ Fase: Entrevista Individual Aberta}

Os participantes foram contatados por telefone para a marcação da entrevista, tendo-se o cuidado de marcá-la fora do horário da aula. Cada entrevista teve a duração de aproximadamente uma hora e todas foram realizadas por mim.

No início das entrevistas dei todas as informações necessárias a respeito das fases da pesquisa, salientando que não haveria riscos tanto pelos procedimentos utilizados, como pela divulgação dos resultados. Foi garantido o caráter voluntário da participação dos participantes, bem como o anonimato das pessoas e da instituição (os nomes seriam substituídos por nomes fictícios e o da instituição omitido). 0 acesso aos resultados estaria garantido a qualquer momento. Nessa ocasião, o documento de consentimento livre e esclarecido foi assinado (Anexo A).

Segundo Bleger (1998), "a entrevista é um instrumento fundamental do método clínico e é, portanto, uma técnica de investigação científica em psicologia” (p.1). Ela pode ter diversos usos, mas neste caso, o objetivo é diagnóstico, incluído dentro de um objetivo maior que a pesquisa científica.

Bleger se refere aos dois tipos de entrevista: aberta ou fechada. Optei por uma entrevista individual aberta, pois esta, segundo ainda esse autor, "possibilita uma investigação mais ampla e profunda da personalidade do entrevistado" (p. 3), ao mesmo tempo em que a personalidade do participante permite $o$ desenvolvimento da entrevista de forma flexível por parte do entrevistador.

A forma individual foi escolhida em função da necessidade de se desenvolver um estudo da personalidade de cada integrante do grupo, antes do início da intervenção.

$\mathrm{Na}$ entrevista com cada participante, foram coletados dados de identificação, informações sobre as principais fases da vida (infância, adolescência, vida adulta e velhice) e sobre pontos importantes como carreira profissional, vida familiar, sexualidade e o motivo para participar do estudo.

Foram realizadas dez entrevistas.

No final da entrevista foram marcados dia e horário para a aplicação do Método de Rorschach, e foi feito um levantamento da disponibilidade de horário e dia para o desenvolvimento das sessões. 


\subsection{2. $2^{\mathrm{a}}$ Fase: Método de Rorschach}

A escolha do Rorschach para, juntamente com a entrevista inicial, avaliar a psicodinâmica dos participantes, levou em conta a importância que essa técnica tem no cenário do diagnóstico psicológico. Autoras (Schwarz, 2002; Pasian, 2000) afirmam que o Método de Rorschach é um dos instrumentos de avaliação psicológica mais utilizado em todos os países. Vaz (1997), referindo-se às duas sociedades científicas existentes no Brasil, que congregam centenas de psicólogos estudiosos do Rorschach, faz um histórico assinalando a evolução crescente dos estudos a respeito dessa técnica no nosso país.

O referencial teórico adotado para a aplicação e a análise do Rorschach nesta pesquisa é o proposto por Bruno Klopfer ${ }^{1}$ (Klopfer \& Kelly, 1946/1972).

Para análise das respostas, utilizei o Atlas proposto por Gavião (2002) e os dados normativos estabelecidos por essa autora, para a faixa de 60 anos ou mais. Uma cópia da aplicação, sem a devida codificação, foi enviada a um segundo avaliador para posterior comparação das análises e verificação do nível de concordância. As respostas que apresentaram codificações divergentes foram avaliadas por um terceiro avaliador.

A aplicação do teste teve a duração de cerca de uma a duas horas, e foi realizada por mim.

Os dez participantes compareceram à aplicação da técnica.

No final da aplicação, o dia e o horário para o início das sessões foram confirmados.

\subsection{3. $3^{\text {a }}$ Fase: A Psicoterapia Grupal Breve}

Compreendeu onze sessões, uma por semana, com duração de $1 \mathrm{~h} 20^{\prime}$ cada sessão.

\footnotetext{
${ }^{1}$ O Método de Rorschach, analisado a partir da linha teórica de Bruno Klopfer, foi recomendado pelo CFP.
} 
Em todas as sessões, diversas folhas sulfite, folhas A2, e folhas de Flip-Chart, lápis preto $n^{\circ} 2$ e giz de cera ficaram à disposição dos participantes, sobre uma mesa, caso quisessem se expressar de forma não-verbal.

A folha branca foi escolhida por poder representar todas as possibilidades possíveis, e o giz de cera e o lápis preto $n^{\circ} 2$ por proporcionarem condições menos ameaçadoras e menos regressivas que outros materiais.

A observadora foi apresentada ao grupo no início da primeira sessão como uma psicóloga que colaboraria registrando todo o desenvolvimento do trabalho.

Essa colaboradora sentou-se ao lado da mesa em que ficavam os materiais e manteve-se em silêncio anotando as sessões, inclusive a de follow up.

Durante as sessões o grupo expressou-se por meio da verbalização, dos desenhos e dos sonhos.

No final da última sessão, foi agendado o horário para a reaplicação do Rorschach.

\subsection{4. $4^{\mathrm{a}}$ Fase: Reaplicação do Método de Rorschach}

A reaplicação teve duração de cerca de uma a duas horas, se desenvolveu após uma semana da última sessão e foi realizada por mim.

O objetivo da reaplicação da técnica era a comparação dos resultados desta etapa com os da aplicação e com a análise das sessões.

Após a retestagem, me coloquei à disposição para uma sessão de follow up, após três meses, caso os participantes tivessem interesse.

Todos foram consultados no final do reteste e manifestaram interesse em participar da sessão de follow up.

Combinei com o grupo que, apo dois meses e meio, entraria em contato por telefone para o devido agendamento da sessão de follow up. 


\subsection{5. $5^{\mathrm{a}}$ Fase: Follow up}

Esta última sessão, visando acompanhar o desenvolvimento do grupo, após o término da Psicoterapia Grupal Breve, foi realizada após três meses e com seis participantes. A sétima, por telefone, justificou sua ausência com antecedência.

Nesta pesquisa, esse procedimento de acompanhamento teve como objetivo verificar as mudanças ocorridas com o grupo após o término das sessões. Através de uma sessão complementar, verificou-se como os participantes tinham vivenciado o período de três meses após o fim do processo psicoterápico.

No final dessa etapa, coloquei-me à disposição para uma outra sessão, caso o grupo considerasse necessário, mas nenhum dos participantes se pronunciou.

\subsection{Local}

Local das entrevistas e da aplicação do Método de Rorschach: uma sala de reuniões com uma mesa oval e cadeiras.

Local dos atendimentos: uma sala de aula. As cadeiras, com apoio para o braço, foram dispostas em semicírculo, havendo uma pequena mesa retangular onde os materiais gráficos ficaram dispostos.

As entrevistas, o teste e as sessões sempre se desenvolveram em horário em que não havia aula ou outra atividade que pudesse interferir no projeto.

O dia da semana e o horário dos atendimentos foram constantes durante todo o processo, exceção feita na existência de um feriado. Previamente, o grupo foi consultado sobre a alteração de data e nova data foi escolhida. 


\section{CAPÍTULO VIII}

\section{RESULTADOS}

\subsection{Análise Qualitativa das Entrevistas e Perfil do Sujeito Coletivo}

Como já foi mencionado anteriormente, os participantes foram convidados e participaram espontaneamente do trabalho grupal, sendo que os critérios foram: a idade - esta deveria estar compreendida na faixa de 60 a 70 anos, e a inexistência de histórico de doenças incapacitantes e de doenças psiquiátricas graves.

No início da entrevista, após todos os esclarecimentos a respeito do projeto, o documento de consentimento livre e esclarecido foi assinado.

Todos os participantes nasceram em famílias de nível sociocultural e econômico baixo, com muitos filhos, sendo que só uma participante cursou universidade antes do casamento. Duas puderam cursar o terceiro grau após o casamento, dois participantes cursaram apenas o $1^{\circ} \mathrm{grau}$, uma fez o curso técnico e um estudou até o colegial. Todos procuraram a Universidade da Terceira Idade visando estudar, se atualizar e fazer contatos sociais.

Todos tiveram que trabalhar muito cedo e colaborar para o sustento da família, o que revela serem pessoas que tiveram que amadurecer precocemente e arcar com responsabilidades próprias do mundo adulto, ainda quando crianças. Cinco participantes estão aposentados. A preocupação com a situação financeira precária aparece em um participante de forma mais acentuada, os demais demonstrando ter uma condição de vida mediana.

Todos casaram no cartório e na igreja, atualmente uma é viúva, duas são desquitadas e os demais se mantêm casados. Todos têm mais de um filho, chegando no máximo a três. Suas relações familiares parecem ser razoavelmente estruturadas, todos mantêm vínculos afetivos com seus familiares e valorizam a família e as relações de amizade.

Os participantes, de formas diferentes, revelam dificuldades para lidar com o envelhecimento e com as limitações que este acarreta, podendo-se perceber indicadores de auto-estima rebaixada. 
Quase todos (exceção de um) revelaram ter cuidado com a saúde física, mantendo exames rotineiros em dia e tomando a medicação necessária sob orientação médica. Nenhuma doença grave foi relatada, nenhum deles apresentando sintomas graves, apesar de relatarem índices de pressão alta, colesterol, artrose etc.

Os motivos que os levaram a participar da Psicoterapia Grupal Breve foram diversos: sentimentos de tristeza pela morte de um irmão, preocupação com problemas financeiros do filho, percepção de problemas emocionais e pedido de ajuda, curiosidade, necessidade de aprender a lidar melhor com a velhice e os limites físicos inerentes a esta.

As condições acima relatadas e o interesse pelo crescimento pessoal caracterizam esse grupo de pessoas idosas, e, em princípio, sinalizam que elas possuem bons recursos internos e disponibilidade para participar de uma Psicoterapia Grupal Breve, como proposto por esta pesquisa.

\subsection{Tabelas}

1.2.1. Relação dos Índices Utilizados, de Acordo com o Sistema de Klopfer (Klopfer \& Kelly, 1946/1972), com a teoria desenvolvida por esse autor

Com o objetivo de facilitar a compreensão dos resultados analisados no Rorschach, apresento abaixo uma síntese das hipóteses interpretativas relacionadas a cada índice. 
Tabela 1a - Aspectos Intelectuais

\begin{tabular}{|c|c|}
\hline ndices & Hipóteses interpretativas \\
\hline $\mathrm{R}$ & capacidade produtiva \\
\hline G & capacidade de integrar fatos e aspectos separados da experiência \\
\hline D & capacidade de lidar com os aspectos práticos da realidade \\
\hline $\mathrm{Dd}$ & atenção às minúcias e aos detalhes \\
\hline $\mathrm{F}$ & $\begin{array}{l}\text { controle racional, capacidade de avaliar uma situação com } \\
\text { objetividade }\end{array}$ \\
\hline $\mathrm{F}+$ & acuidade perceptiva, precisão e coerência do pensa \\
\hline$F-$ & teste de realidade prejudicado, pensamento lóg \\
\hline G:M & relação do nível de aspiração com recursos in \\
\hline A & (conteúdo animal) nível de estereotipia do pe \\
\hline $\mathrm{H}$ & (conteúdo humano) interesse nas relações int \\
\hline Ban & capacidade de adaptação e ajustamento às sit \\
\hline ndices & Hipóteses interpretativas \\
\hline & nível de sensibilidade à situação emocional \\
\hline $\mathrm{FC} / \mathrm{CF} / \mathrm{C}$ & capacidade de manifestacão emocional \\
\hline $\mathrm{FC}^{\prime} / \mathrm{C}^{\prime} \mathrm{F} / \mathrm{C}$ & manifestação emocional mais cautelosa, ìndicativo de depressão \\
\hline M & $\begin{array}{l}\text { recursos do mundo interno, controle interno, capacidade de empatia, } \\
\text { recursos intelectuais }\end{array}$ \\
\hline FM & representa os instintos e impulsos \\
\hline $\mathrm{m}$ & conflitos internos, tensão interna \\
\hline $\mathrm{Fc} / \mathrm{cF} / \mathrm{c}$ & $\begin{array}{l}\text { necessidade de contato social, "tato" nas relações interpessoais, } \\
\text { sensibilidade }\end{array}$ \\
\hline FK/KF/K & $\begin{array}{l}\text { envolvem diferentes mecanismos frente a situação de tensão e } \\
\text { pressão } \quad \text { externa. Indicam nível de ansiedade situacional. }\end{array}$ \\
\hline $\mathrm{Fk} / \mathrm{kF} / \mathrm{k}$ & indicadores de ansiedade \\
\hline M: Csum & $\begin{array}{l}\text { tipo de vivência: extratensivo, introversivo, ambigual (dilatado, } \\
\text { coartado ou coartativo) }\end{array}$ \\
\hline
\end{tabular}


Tabela 2a - Comparação entre os Resultados de Cada Participante e do Sujeito Coletivo com os Dados Normativos de Gavião (2002), na Situação de Teste (antes da Psicoterapia Grupal Breve).

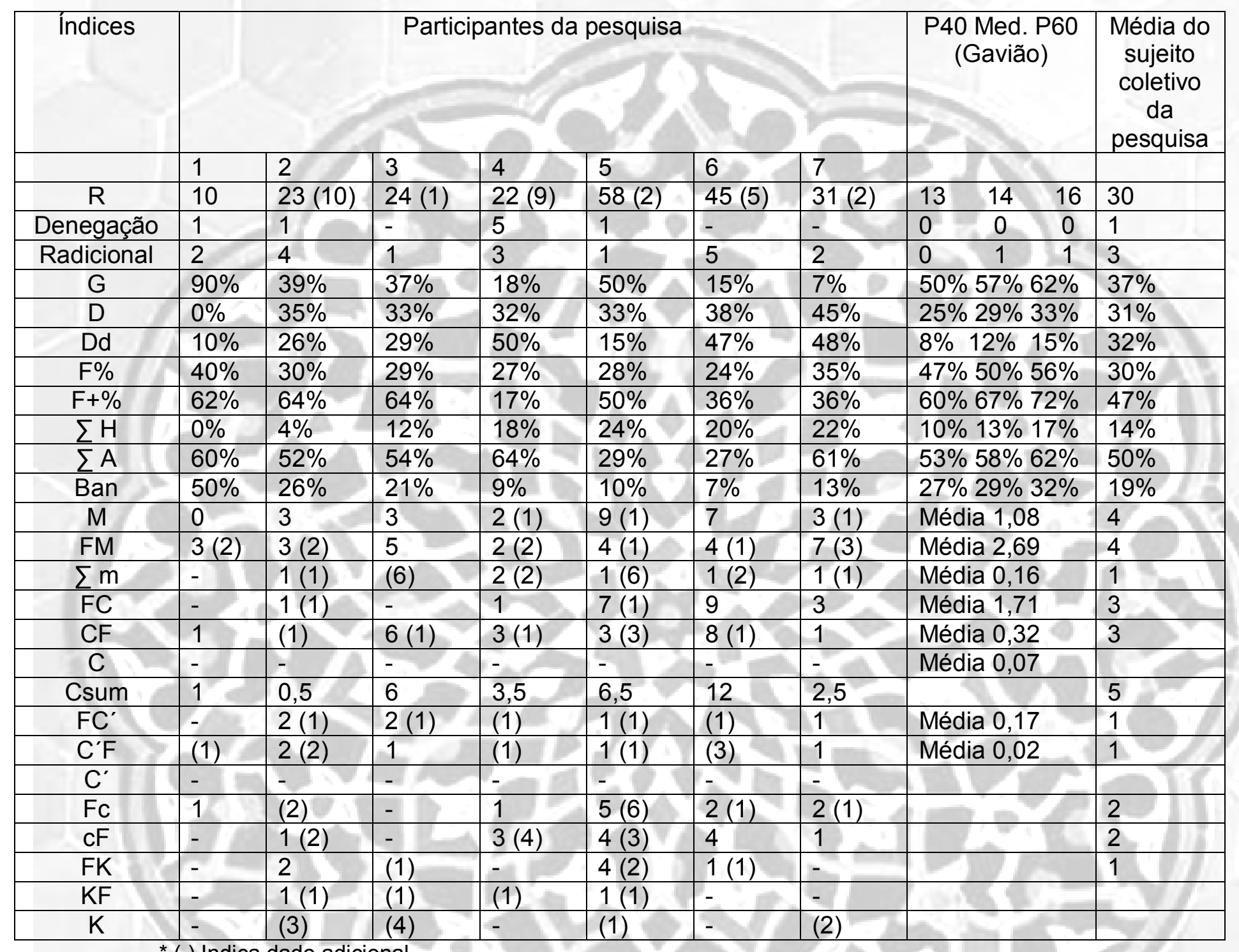


Tabela 2b - Comparação entre os Resultados de Cada Participante e do Sujeito Coletivo com os Dados Normativos de Gavião (2002), na Situação de Reteste (após a Psicoterapia Grupal Breve)



* ( ) Indica dado adicional

1.3. Análise Comparativa entre os Resultados da Aplicação do Rorschach e os do Reteste, após o Processo de Psicoterapia Grupal Breve, de Cada Participante

A análise foi desenvolvida integrando os aspectos intelectuais (capacidade produtiva, abordagem intelectual, funcionamento lógico, amplitude de interesses, capacidade de ajustamento e nível de aspiração) e os aspectos afetivos (controle 
emocional, tipo de vivência, mundo interior, controle interno e desenvolvimento afetivo-emocional).

\subsubsection{Participante Cássia}

\section{ASPECTOS INTELECTUAIS}

- A sua capacidade produtiva se manteve rebaixada, havendo redução das respostas adicionais após o processo psicoterápico. $\mathrm{O}$ número de Denegações se manteve inalterado, acima da média.

- Quanto ao tipo de enfoque da realidade, observaram-se aumento da atenção às minúcias, melhora na capacidade de lidar com os aspectos práticos da realidade, e capacidade de integrar dados dentro da média (no teste, esta capacidade era acentuada).

- Seu controle racional e sua acuidade perceptiva sofreram redução após a intervenção.

- Seu nível de aspiração se mantém mais elevado que seus recursos internos, provavelmente gerando sentimentos de frustração.

- Quanto à sua diversidade de interesses observou-se redução no nível de estereotipia do pensamento após a intervenção (abaixo dos limites esperados). Após o processo psicoterápico, observei um interesse maior nas relações interpessoais, mas os índices se mantiveram abaixo da média. A maioria dos conteúdos escolhidos, nas duas etapas, evidencia tentativa de fuga e evasão.

- Notei melhora nos seus recursos adaptativos e capacidade de ajustamento, mas continuam alterados em função da excessiva preocupação com o grupo e dos sentimentos de forte dependência.

\section{ASPECTOS AFETIVOS}

- No reteste, Cássia mostrou-se igualmente estimulável pelos estímulos emocionais do meio, mas apresentou indícios de maior manifestação 
emocional, tanto através de respostas emocionais socializadas, como de respostas mais espontâneas. Os sinais de interferência de perturbação emocional no processo de pensamento e dificuldade para um contato real com a situação emocional não apareceram no reteste.

- Seu tipo de vivência de Coartado passou a ser Extratensivo e sua tendência passou de Introversiva para Ambigual.

- Os indicadores de imaturidade emocional se mantiveram.

\subsubsection{Participante Denise}

\section{ASPECTOS INTELECTUAIS}

- Após a intervenção, sua capacidade produtiva sofreu redução, mas mesmo assim se manteve acima da média. As respostas adicionais e as Denegações se mantiveram acima do esperado.

- Quanto ao tipo de enfoque da realidade, observou-se mudança no sentido de uma maior capacidade de atenção aos aspectos práticos da realidade (que se mantém acima da média), redução significativa da atenção às minúcias e melhora na capacidade de integração de dados (dentro da média). Observou-se também redução da crítica.

- Seu controle racional se manteve rebaixado e sua acuidade perceptiva sofreu acentuada redução.

- Seu nível de aspiração se mantém muito mais elevado que seus recursos internos, provavelmente gerando sentimentos de frustração.

- Quanto à sua diversidade de interesses, observou-se um aumento significativo no nível de estereotipia para excessiva estereotipia do pensamento e a dificuldade nas relações interpessoais se manteve. A maioria dos conteúdos, escolhidos no reteste, evidencia tentativa de fuga e evasão, tal como aconteceu durante a situação de teste. Observei, no reteste, redução dos conteúdos que indicam disforia de tipo ansioso.

- Seus recursos adaptativos e sua capacidade de ajustamento, no período de teste, estavam prejudicados e sinalizavam que Denise tinha dificuldade 
para pensar como os outros. Na situação de reteste, observei melhora nestes indicadores no sentido de preocupação com o grupo e sentimentos de dependência.

\section{ASPECTOS AFETIVOS}

- Nas duas situações, Denise demonstrou ser pouco estimulável frente aos estímulos emocionais do meio e ter reação emocional inibida.

- Os sinais de interferência de perturbação emocional no processo de pensamento e dificuldade para um contato real com a situação emocional apareceram mais intensamente na situação de teste do que no reteste.

- Nos dois momentos, constatei indícios de que Denise passou por experiência traumática que gerou comportamento de esquiva das relações, para evitar novos sofrimentos.

- Há indícios de que as necessidades afetivas estão mal integradas à personalidade.

- Seu tipo de vivência de Introversiva passou a ser Coartativa e sua tendência se manteve Extratensiva.

- Os indicadores de imaturidade emocional se mantiveram.

\subsubsection{Participante Cléo}

\section{ASPECTOS INTELECTUAIS}

- Cléo apresentou redução na sua capacidade produtiva durante o reteste, mas mesmo assim seus índices estão dentro da média (no teste observouse hiperprodutividade). Suas respostas adicionais, após o processo psicoterápico, aumentaram e o seu número de Denegações se manteve dentro do esperado.

- Quanto ao tipo de enfoque da realidade, a excessiva atenção às minúcias se manteve, bem como a acentuada crítica intelectual. Na situação de reteste, observei menor capacidade de atenção aos aspectos práticos da 
realidade, e melhora nas suas condições de integrar dados e generalizar (dentro da média).

- Seu controle racional melhorou na situação de reteste, quando comparado ao índice do período de teste, mas, mesmo assim, se manteve rebaixado. Sua acuidade perceptiva melhorou no reteste, ficando dentro dos limites aceitáveis.

- Seu nível de aspiração se manteve muito mais elevado que seus recursos internos, provavelmente gerando sentimentos de frustração.

- Quanto à sua diversidade de interesses, observei redução no nível de estereotipia do pensamento no reteste (abaixo da média). Na situação de reaplicação, notei um maior interesse pelas relações humanas, indícios de melhora na auto-estima e redução dos conteúdos que indicam impulsividade e descontrole.

- Seus recursos adaptativos e sua capacidade de ajustamento, prejudicados durante a situação de teste, revelaram-se mais adequados durante o reteste.

\section{ASPECTOS AFETIVOS}

- No reteste, Cléo mostrou-se menos estimulável pelos estímulos emocionais do meio e mais inibida na sua manifestação emocional.

- Observei que, antes do processo psicoterápico, Cléo apresentava dificuldade no controle emocional (excessivo descontrole), condição esta que foi alterada no sentido de um controle mais adequado e de capacidade de resposta emocional socializada.

- As respostas, que no momento do teste refletiam acentuada sensibilidade depressiva, tiveram seu número reduzido no reteste.

- Foram observados, inicialmente, indicadores de distúrbio grave na área das necessidades afetivas caracterizado por excesso de ansiedade e a presença de mecanismos defensivos. Após a psicoterapia, o nível de ansiedade foi reduzido. Portanto, notei a presença de indicadores de razoável estabilidade afetiva após o processo psicoterápico. 
- Seu tipo de vivência Extratensivo passou a ser Introversivo e sua tendência Introversiva se manteve na situação de reteste.

- Os indícios de imaturidade emocional se mantiveram no reteste, mas observei redução no nível de tensão interna pós-psicoterapia.

\subsubsection{Participante Davi}

\section{ASPECTOS INTELECTUAIS}

- A sua capacidade produtiva se manteve muito acima da média e a má qualidade predominou nos dois momentos. Na situação de reteste, houve redução das respostas adicionais, ficando, nesta etapa, dentro da média. As Denegações também sofreram redução após a intervenção, mas continuaram acima do esperado.

- Quanto ao tipo de enfoque da realidade, predominaram a atenção às minúcias (manteve-se acentuada) e a dificuldade na integração de dados (acentuada). Na situação de reteste, observei redução da crítica. Sua dificuldade para lidar com as questões práticas aumentou após o processo psicoterápico. Na situação de reteste, indícios de limitação intelectual também foram observados.

- No reteste, seu controle racional melhorou (dentro da média). Sua acuidade perceptiva continuou muito prejudicada, e os sinais de fragilidade egóica se mantiveram.

- Seu nível de aspiração é maior que seus recursos internos, o que, provavelmente, gera sentimentos de frustração.

- Quanto à sua diversidade de interesses, observaram-se indicadores de excessiva estereotipia do pensamento nas duas situações, e o interesse pelas relações interpessoais se manteve dentro do esperado. Notei, no reteste, redução nos indícios de ansiedade e de medo relacionados ao contato humano.

- Seus recursos adaptativos e sua capacidade de ajustamento se mantiveram prejudicados no período de reteste. 


\section{ASPECTOS AFETIVOS}

- Nas duas situações, Davi demonstrou ser muito estimulável frente aos estímulos emocionais do meio. Sua manifestação emocional, antes mais aberta, tornou-se inibida após o processo psicoterápico. É importante salientar que, durante a situação de teste, predominaram reações emocionais descontroladas e infantilizadas, enquanto, no reteste, houve redução desse tipo de resposta.

- Há indícios de que suas necessidades afetivas não estão bem integradas à personalidade e que há dificuldades no ajustamento.

- Seus recursos egóicos são insuficientes e insatisfatórios para lidar com suas necessidades afetivas, que se caracterizam por carência afetiva profunda, necessidade de contato do tipo infantil e sentimentos sensuais.

- Seu tipo de vivência, na situação de teste, foi Extratensiva e, no reteste, Coartativa, e sua tendência se manteve Ambigual Dilatado.

- Os indicadores de imaturidade emocional se mantiveram no reteste, mas observei redução da pressão dos impulsos mais primitivos e da tensão interna sobre o ego.

\subsubsection{Participante Anita}

\section{ASPECTOS INTELECTUAIS}

- A sua capacidade produtiva, durante o reteste, sofreu redução, mas mesmo assim se manteve muito acima da média (hiperprodutividade). Houve redução das respostas adicionais e das Denegações, ficando estas na média.

- Quanto ao tipo de enfoque da realidade, houve aumento de atenção às minúcias e o nível de crítica intelectual se manteve excessivo. Na situação reteste, houve redução na capacidade de atenção às situações mais 
práticas, ficando abaixo da média. Sua capacidade de integrar dados e de generalizar se manteve dentro do esperado

- No reteste, seu controle racional se manteve rebaixado e sua acuidade perceptiva melhorou, ficando acima da média (preocupação excessiva com a precisão).

- Seu nível de aspiração é maior que seus recursos internos. Observei que o excesso de fantasia, que interferia nessa relação na situação de aplicação, sofreu redução no reteste.

- Quanto à diversidade de interesses, observaram-se, nas duas situações, indicadores de estereotipia do pensamento abaixo da média e muito interesse pelas relações interpessoais. Notei, no reteste, redução nos indícios de ansiedade e de medo relacionados ao contato humano, embora as dificuldades decorrentes da auto-imagem negativa e da incorporação prejudicada do humano permaneceram. Conteúdos relacionados a tendências de fuga e de evasão foram freqüentes nas duas situações.

- Seus recursos adaptativos e sua capacidade de ajustamento se mantiveram prejudicados no período de reteste.

\section{ASPECTOS AFETIVOS}

- Nas duas situações, Anita demonstrou ser muito estimulável frente aos estímulos emocionais do meio e manifestou abertamente suas emoções. Há indícios de controle emocional sobre as respostas mais infantilizadas e descontroladas, mas nas duas situações observei que, embora predominem respostas emocionais socializadas, muitas vezes, o impacto emocional causa distorção da realidade e prejudica a eficácia desse controle.

- Há indícios de consciência de suas necessidades afetivas, mas sinais de carência afetiva profunda e necessidades sensuais apontam para dificuldade na integração dessas necessidades ao resto da personalidade. Observei redução desses sinais na situação de reteste. 
- Seu tipo de vivência, nos dois momentos, foi Introversiva, e sua tendência se manteve Extratensiva.

- Tanto no teste como no reteste, observei que há indícios de recursos egóicos para um controle interno adequado, mas a presença de fantasias escapistas prejudica o funcionamento do ego e a eficácia desse controle. No reteste, constatei redução desse tipo de fantasia, e também diminuição da pressão da carga pulsional e da tensão interna sobre o ego. Assim, no reteste, há indícios de um ego com melhores condições de funcionamento e de controle interno.

\subsubsection{Participante Olga}

\section{ASPECTOS INTELECTUAIS}

- A sua capacidade produtiva, no reteste, sofreu redução, mas, mesmo assim, se manteve muito acima da média (hiperprodutividade). O número de respostas adicionais, acima da média, se manteve inalterado e não houve nenhuma Denegação, o que é esperado.

- Nas duas situações, Olga apresentou um enfoque da realidade baseado na atenção excessiva às minúcias e às situações mais práticas. Sua crítica intelectual se manteve acentuada, bem como sua dificuldade na integração de dados.

- No reteste, seu controle racional se manteve rebaixado e sua acuidade perceptiva, antes rebaixada, no reteste, apresentou melhora (índices dentro do esperado).

- Seu nível de aspiração é baixo frente aos recursos internos disponíveis, o que representa limitação na forma de canalizar tais recursos.

- Quanto à sua diversidade de interesses, observou-se, tanto no teste como no reteste, estereotipia do pensamento limitada. $O$ interesse humano (acima da média na situação de teste) sofreu redução no reteste (índices dentro do esperado). Embora apresente interesse pelas relações interpessoais, Olga tem dificuldades acentuadas neste setor, decorrentes 
de ansiedade associada às relações humanas e à incorporação negativa do humano. Apresenta inibição e medo no desenvolvimento desses contatos e tendência à crítica e à análise minuciosa, características estas que também interferem no estabelecimento de um relacionamento saudável. Sua auto-imagem é negativa. Entre os conteúdos escolhidos predominaram, nas duas etapas, aqueles relacionados às suas preocupações somáticas e às suas dificuldades no controle emocional.

- Seus recursos adaptativos e sua capacidade de ajustamento se mantiveram prejudicados no período de reteste.

\section{ASPECTOS AFETIVOS}

- Nas duas situações, Olga demonstrou ser muito estimulável frente aos estímulos emocionais do meio e manifestou abertamente suas emoções. No reteste, observei indícios de melhor controle emocional sobre as respostas mais infantilizadas e descontroladas. Durante a situação de teste, observei sinais de perturbação emocional interferindo no processo lógico do pensamento, o que reflete dificuldade para um contato real com a situação emocional. Esse tipo de interferência não pareceu no reteste.

- Na reaplicação, percebi também que houve redução das respostas emocionais mais descontroladas e infantis. Nas duas situações notei a presença de resposta emocional expressa com esforço e tensão. Há sinais de sensibilidade depressiva, mas o seu controle emocional, no reteste, parece ser suficiente para lidar com tal condição.

- Após a psicoterapia, observei a existência de melhores recursos para lidar com suas necessidades afetivas e de integrá-las ao resto da personalidade.

- Seu tipo de vivência, nos dois momentos, foi Extratensiva e sua tendência se manteve Extratensiva.

- No teste observei a presença de fantasias escapistas que, provavelemente, prejudicam o funcionamento do ego e a eficácia do controle interno. No reteste, constatei redução desse tipo de fantasia e também diminuição da pressão da carga pulsional e da tensão interna 
sobre o ego. Assim, no reteste, há indícios de um ego com melhores condições de funcionamento e de controle interno.

\subsubsection{Participante Marta}

\section{ASPECTOS INTELECTUAIS}

- A sua capacidade produtiva se manteve muito acima da média. No reteste, houve redução no número de respostas adicionais, ficando dentro do esperado, e não houve nenhuma Denegação, o que é esperado.

- Nas duas situações, Marta apresentou um enfoque da realidade baseado na atenção excessiva às minúcias e às situações mais práticas. Sua crítica intelectual se manteve acentuada, bem como sua dificuldade na integração de dados.

- No reteste, seu controle racional se manteve rebaixado e sua acuidade perceptiva prejudicada.

- O nível de aspiração limitado frente aos seus recursos internos, observado na situação de teste, sofreu alteração, durante o reteste, no sentido de aumento desse nível de ambição e de melhora na qualidade dos recursos internos.

- Quanto à sua diversidade de interesses, observou-se, nas duas situações, a presença de indicadores de estereotipia do pensamento dentro da média esperada. O interesse humano, acima da média durante o teste, sofreu pequena redução após a psicoterapia (mas permaneceu dentro da média). Embora apresente sinais de interesse pelas relações interpessoais, Marta demonstra ter dificuldades acentuadas neste setor, decorrentes de ansiedade associada às relações humanas e à incorporação negativa do humano. Apresenta sinais de inibição e de medo no desenvolvimento desses contatos e tendência à crítica e à análise minuciosa, características que também interferem no estabelecimento de um relacionamento saudável. Após a psicoterapia, verifiquei que houve 
redução da ansiedade, da tendência à crítica e dos indicadores de autoimagem negativa. A maioria dos conteúdos escolhidos, nas duas etapas, evidencia interesse mais voltado para o plano concreto e prático, pouca criatividade e a presença de conteúdos indicativos de disforia de tipo ansioso.

- Seus recursos adaptativos e sua capacidade de ajustamento se mantiveram prejudicados no período de reteste.

\section{ASPECTOS AFETIVOS}

- Na aplicação, Marta demonstrou ser pouco estimulável frente aos estímulos emocionais do meio e manifestar abertamente suas emoções. Após a psicoterapia, Marta manteve os indicadores de controle emocional adequado sobre as respostas mais infantilizadas e descontroladas.

- Há indicadores, no reteste, de maior consciência de suas necessidades afetivas, mas também de maior dependência da aprovação do meio.

- Seu tipo de vivência foi Introversiva e passou a Extratensiva na reaplicação e sua tendência Introversiva nas duas situações.

- Tanto no teste como no reteste, observei indicadores de poucos recursos egóicos para lidar com a intensa carga pulsional. No reteste, a mudança observada foi no sentido de redução do nível da tensão interna, mas permanece a excessiva pressão sobre o ego. Os indícios de imaturidade emocional se mantiveram.

1.4. Análise Comparativa entre os Resultados do Sujeito Coletivo na Aplicação do Rorschach e na Reaplicação, após a Psicoterapia Grupal Breve

\section{ASPECTOS INTELECTUAIS}

- O sujeito coletivo deu um número alto de respostas nas duas situações, mas observei redução no número de respostas na reaplicação. 
- Analisando-se a responsividade individual, notei também redução do número de respostas no reteste.

- O número de respostas adicionais também sofreu redução na aplicação após o tratamento psicoterápico e o de Denegações se manteve acima da média. Essas reduções podem decorrer de uma menor ansiedade na situação de reaplicação pelo fato de a situação já ser conhecida, e/ou em decorrência do próprio processo psicoterápico.

- Quanto ao tipo de enfoque intelectual da realidade, o sujeito coletivo apresentou muita atenção às minúcias nas duas situações, revelando a predominância de um tipo de apreensão de caráter mais subjetivo. A atenção aos aspectos práticos da realidade manteve-se dentro do esperado nos dois momentos. Constatou-se muita dificuldade quanto à capacidade de uma visão mais abrangente e integradora dos dados da realidade, essa dificuldade perdurando após a intervenção psicoterápica. O nível significativo de crítica intelectual pode revelar a presença de ansiedade situacional nos dois momentos.

- Observei que, tanto na aplicação como no reteste, o enfoque detalhista foi mais freqüente nas prancha $X$. $O$ maior número de respostas do Rorschach, durante o teste, foi nas pranchas III e $\mathrm{X}$ e, no reteste, na prancha II. Nenhuma prancha foi recusada pelo sujeito coletivo nas duas situações.

- Quanto ao controle racional e à utilização de recursos intelectuais de forma efetiva, o sujeito coletivo revelou ter dificuldades nesse tipo de controle e uma acuidade perceptiva perturbada, tanto na aplicação como na reaplicação, o que pode estar relacionado às suas dificuldades emocionais.

- Após o processo psicoterápico, observei maior equilíbrio entre o nível de aspiração e os recursos internos do sujeito coletivo.

- Quanto às áreas de interesse, após a intervenção, observei maior capacidade perseverativa e concentração, os resultados encontrando-se dentro do esperado. O interesse pelo relacionamento interpessoal se manteve dentro dos limites esperados, mas verifiquei que, após o processo psicoterápico, houve redução do nível de crítica e de análise 
detalhista, e um menor nível de ansiedade e de medo associados a essa área.

- Outras áreas se destacaram como importantes para o sujeito coletivo, destacando-se aquelas que refletem mecanismos defensivos direcionados para fuga e a evasão. Conteúdos relacionados à impulsividade e ao descontrole não reapareceram após a psicoterapia.

- O sujeito coletivo, provavelmente, por estar muito voltado para o próprio mundo interno, muito mobilizado por suas questões emocionais, apresentou dificuldade na capacidade de adaptação ao meio e de participação do pensamento do grupo.

\section{Aspectos Afetivos}

- O sujeito coletivo, nas duas situações, mostrou-se altamente estimulável frente aos estímulos emocionais do meio externo, apresentando afetividade viva e desinibida, revelando interesse em relacionar-se com o meio que o cerca.

- Em relação ao grau de controle externo sobre suas reações afetivas, o sujeito coletivo manteve um controle emocional satisfatório, mas é importante registrar que houve redução das respostas emocionais mais impulsivas e espontâneas, durante o reteste.

- Nos dois momentos, constatou-se a presença de indicadores de instabilidade emocional, mas esta condição não é exclusiva dessa faixa etária, aparecendo tanto na pesquisa de Gavião (2002), como também entre os adultos estudados por Pasian (2000).

- Na situação de aplicação, não houve predominância de nenhum tipo de vivência afetiva, e, no reteste, o tipo Extratensivo predominou. A tendência Extratensiva foi freqüente tanto na situação de aplicação, como na reaplicação.O sujeito coletivo demonstrou imaturidade emocional tanto na aplicação como no reteste. 


\subsection{Análise das Sessões}

\section{O Primeiro Contato com os Participantes}

As entrevistas iniciais já se constituíram num primeiro momento de construção do vínculo comigo, embora ainda o fosse através de uma relação dual, e também forneceram informações importantes sobre as condições dos participantes no que se refere à história de vida e às possíveis crises vividas. Da análise das entrevistas, pude constatar, de modo geral, que os participantes possuíam recursos internos razoáveis para se beneficiarem do processo terapêutico. Autores como Fiorini e Peyrú (1978) e Knobel (1986) apontaram alguns critérios para encaminhamento de um cliente para um trabalho breve, tais como: início recente dos transtornos, capacidade egóica e motivação para o tratamento.

No caso deste grupo de idosos, é importante lembrar que não partiu deles a iniciativa de procurar o tratamento, mas foram convidados a participar de uma pesquisa que envolvia a possibilidade de participar de um tipo de processo psicoterápico. Mesmo assim pude perceber um bom nível motivacional inicial por parte de sete participantes, na medida em que se dispuseram a comparecer em vários horários para a execução das diferentes fases da pesquisa. Os outros três (o grupo inicial era composto de dez participantes) demonstraram motivação para as entrevistas e para a aplicação do Método de Rorschach, mas não para o processo terapêutico: uma não compareceu em nenhuma das sessões, outra compareceu às quatro primeiras sessões e a terceira desistiu após a $5^{\mathrm{a}}$ sessão.

Quanto ao critério que envolve a duração do sofrimento psíquico, pude observar que a maioria dos participantes relatou dificuldades emocionais antigas, alguns apontando a infância e problemas nas relações familiares, outros revelando problemas nas relações conjugais e no processo de separação. Duas participantes trouxeram queixas diferenciadas: uma vivendo um luto com características patológicas e a outra justificando sua participação em função de curiosidade pessoal.

Quanto aos recursos egóicos, que foram analisados de forma mais profunda a partir do Método de Rorschach, pude verificar, através das entrevistas, que a maioria dos participantes apresentava indícios de maturidade psíquica razoável para 
responder ao processo terapêutico. Três participantes apresentaram um nível de ansiedade alto e indícios de instabilidade emocional durante as entrevistas, mas tais condições não chegaram a prejudicar suas funções cognitivas ou outras funções egóicas que pudessem contra-indicar o processo psicoterápico. Lembro aqui que os mesmos autores acima relacionados apontam dois aspectos básicos para contraindicar a Psicoterapia Breve: um diagnóstico clínico que aponte a existência de personalidade psicopática, psicose, drogadição, obsessões graves, entre outros, e um diagnóstico psicodinâmico que acuse fragilidade egóica, tendência ao acting-out e questões psicodinâmicas que comprometam o desenvolvimento de vínculos e o estabelecimento do foco.

O número de integrantes, dez, proposto inicialmente, visava favorecer uma comunicação adequada entre os diferentes participantes e entre mim e eles e a redução para sete favoreceu ainda mais essa comunicação.

\section{Primeira Sessão: O Estabelecimento do Enquadre}

A primeira sessão caracterizou-se inicialmente por reunir todos os participantes que já tinham tido um contato individual comigo na fase da entrevista e do Método de Rorschach, e por apresentar a eles a observadora.

Neste trabalho, a participação da observadora teve o propósito de observar e registrar as inter-relações do grupo e eu, a inter-relação entre os membros do próprio grupo e as desenvolvidas entre o grupo e ela própria.

Desde as duas primeiras sessões, considero que consegui propiciar a continência grupal através do enquadre e das condições de acolhimento e segurança. Tanto Zimerman (2000), como Zinkin (1998) consideram que o estabelecimento do enquadre possibilita a continência grupal.

Ao definir o local e como este seria utilizado, horário, limite no número de sessões, a importância da presença, assegurar o sigilo e estabelecer o foco do trabalho grupal, eu tinha o objetivo de criar condições para que um espaço físico pudesse ser transformado em um campo psicológico, ou, como diz Freitas (2005), "num campo simbólico constelado que acolhe e conduz ao conceito de self grupal" (p. 58) em que forças dinâmicas de separação e de coesão atuam e podem se harmonizar e gerar vitalidade. 
A centralidade proposta pela disposição das cadeiras também é avaliada por Freitas como um fator que organiza o espaço, ao mesmo tempo centrífugo e centrípeto, de onde a energia pode fluir e se irradiar para todo campo simbólico. A esse respeito é interessante observar que, com o decorrer das sessões, alguns participantes alteravam suas cadeiras tentando, ora se aproximar um do outro, ora procurando se afastar. Este tipo de conduta também aconteceu, principalmente nas primeiras sessões, em relação à observadora. Esse movimento reflete com clareza que as relações afetivas estavam se desenvolvendo e o campo simbólico se estruturando.

Alguns participantes chegavam mais cedo e começavam a conversar e, quando eu chegava, o grupo já estava discutindo algum assunto. Geralmente, eu iniciava a sessão buscando relacioná-lo com o foco estabelecido, e encaminhava a sessão de forma que todos pudessem se manifestar a respeito dele. Tal procedimento pareceu também ter efeito estruturante, propiciando segurança e confiança para o grupo, fazendo com que os participantes sentissem que uma direção "invisível" estava sendo seguida. Essas condições foram fundamentais para que gradativamente, os participantes do grupo desenvolvessem relações afetivas entre si, comigo e com a observadora, e que percebessem a existência de uma conduta estável e coerente da minha parte.

Nesta pesquisa, por se tratar de uma Psicoterapia Grupal Breve, a seleção de um foco também favoreceu a formação do grupo. Pude constatar que o foco, após ter sido ser delimitado, passou a ser o ponto de convergência da minha atenção e dos participantes e, portanto, foi considerado também uma força estruturante no grupo.

As entrevistas e os desenhos temáticos possibilitaram que se elegesse 0 foco ou o tema a ser trabalhado durante o processo psicoterápico. Biangioni (2005) afirma que o foco, numa terapia breve "será o alvo que psicoterapeuta e cliente buscarão atingir, ao centrar sua ação em uma determinada área, procurando transformá-la numa figura pregnante - de acordo com as leis da boa forma da teoria da gestalt - que se sobressai em relação a um fundo demarcado"(p. 3).

O material obtido através das entrevistas e dos desenhos indicou que a maioria dos participantes tinha auto-imagem negativa, auto-crítica acentuada e sentimentos de menos-valia, alguns identificando as origens desses sentimentos no processo de envelhecimento, outros em vivências da infância e/ou em períodos 
posteriores. Essa análise me levou a delimitar a auto-estima como foco a ser trabalhado.

Como seria esperado, no início, a iniciativa foi só minha de orientar o trabalho analítico no sentido de focar a auto-estima, mas, com o decorrer das sessões, o grupo começou também a focalizar esse tema, evidenciando, portanto, um trabalho conjunto que, como na própria análise individual, leva a uma transformação tanto do curador ferido como do grupo.

Para que o trabalho com esse foco - auto-estima - fosse bem desenvolvido, alguns recursos técnicos, como salienta Malan (1981) foram levados em conta. São eles: a Interpretação Seletiva, a Atenção Seletiva e a Negligência Seletiva. As interpretações foram feitas de forma seletiva, sempre buscando relacionar os conteúdos que emergiam com o a questão da auto-estima. Mantive a atenção seletiva tentando sempre observar como e quanto os conteúdos que emergiam estavam relacionados ao foco, e, em função dos objetivos do tratamento, negligenciei os assuntos que, embora parecessem importantes, poderiam nos desviar do foco e causar dispersão.

A análise das duas primeiras sessões já evidenciou a predominância do tema auto-estima. Tanto os comentários antes do início da sessão, como durante esta, já apontavam para as principais preocupações relacionadas ao envelhecimento (queixa sobre os calores da menopausa, preocupações com o aspecto físico envelhecido, sentimento de precisar de ajuda para lidar melhor com as limitações dessa fase e necessidade de mudar escolhas que foram feitas no passado) e ao sentimento de impotência frente às limitações decorrentes desta fase da vida.

Aqui é importante relembrar a posição de Bisker (citado por Osório, 1986) quando este reconhece que os benefícios da psicoterapia grupal são decorrentes tanto do trabalho terapêutico em si, como do processo que se desenvolve fora do âmbito da sessão. Pude verificar que as conversas antes do início da sessão já revelavam o desenvolvimento do vínculo afetivo entre os participantes do grupo sinalizando suas principais preocupações, e entre eles e a observadora, com quem já estabeleciam contato antes do início da sessão, manifestando opiniões ou comentários. Tais atitudes já evidenciavam o desenvolvimento de sentimentos de confiança e receptividade em relação a ela também.

As queixas relacionadas ao envelhecimento no início do processo indicaram que tipo de crise mobilizou e motivou o grupo para o processo terapêutico. A crise 
sinaliza que está havendo repressão da libido e que a energia psíquica não está disponível para o ego, ficando retida no inconsciente. Tal mecanismo acarreta uma condição de fragilização do ego, e, no caso deste grupo de idosos, percebi que essa fragilidade estava relacionada, principalmente, às dificuldades para lidar com as limitações do envelhecimento.

O trabalho psicoterápico foi sendo desenvolvido no sentido de propiciar condições para que essa energia represada fosse gradativamente liberada e que os recursos criativos fossem novamente direcionados para a consciência. O caminho para que esse movimento ocorresse, na Psicoterapia Breve, é através do ego e as minhas intervenções se desenvolveram no sentido de fortalecê-lo.

\section{Segunda Sessão: A Delimitação do Foco Auto-Estima}

A partir da segunda sessão, pude também constatar alguns sinais de desenvolvimento da função "continente" do grupo quando os participantes, que tinham comparecido à primeira sessão, demonstraram capacidade de ser continente das angústias das três participantes que tinham faltado e que se deparavam com a solicitação para que realizassem desenhos temáticos. Nessa ocasião, as participantes que tinham vindo à primeira sessão se propuseram a esperar pelas colegas. Uma delas, Marta quis se ausentar da sala enquanto as novas desenhavam e estranhou quando solicitei que permanecesse no local. Os demais ficaram observando silenciosamente e, muitas vezes, sorriam para aquelas que estavam desenhando. Embora tivéssemos neste momento, como já foi mencionado acima, apenas "um esboço" de grupo, já se delineavam características importantes para o desenvolvimento de um processo grupal: a atitude de aceitação e de acolhimento, por parte dos que já tinham feito os desenhos, sinalizava indícios de formação do self relacional, e o estabelecimento do foco já indicava o início da constelação do self grupal, o que ficaria mais evidente a partir da $5^{a}$ sessão.

Nesta segunda sessão pude também observar indícios de formação de um ego grupal dando suporte para que cada um dos participantes, a partir de uma vivência individual, pudesse sentir o acolhimento e desenvolver o próprio ego no grupo. O acolhimento do outro só pode ocorrer se o próprio indivíduo se acolher, se valorizar, e nesse momento já pude perceber indícios de resgate da auto-estima. 
A participação nessas duas sessões e a disponibilidade para executar o que foi solicitado revelaram também o desenvolvimento de uma boa vinculação entre os próprios membros do grupo, e entre mim e eles. A forma como gradativamente os participantes se reportavam à observadora (alguns olhares, sorrisos, aproximação da cadeira etc.) sinalizava um vínculo positivo com ela e esse acolhimento por parte dos participantes e da observadora também foi fundamental para o desenvolvimento do self relacional.

A solicitação, nas primeira e segunda sessões, para que fizessem os desenhos temáticos e ficassem atentos aos seus sonhos e tentassem registrá-los, representou um estímulo para que cada participante iniciasse um diálogo entre consciente e inconsciente. Embora essa estimulação visasse, inicialmente, a um trabalho individual, o objetivo final era o desenvolvimento do self grupal. O desenvolvimento deste propiciava continência para as vivências arquetípicas no grupo, que passaria a ter um núcleo energético próprio.

Quando solicitei que desenhassem a idéia que emergisse a partir do tema dado, não se preocupando com aspectos estéticos e se o desenho estava certo ou errado, procurei reduzir a ansiedade frente a uma situação que poderia ser sentida como um teste e eliminar, ou pelo menos, minimizar atitudes de crítica que pudessem boicotar a espontaneidade e a criatividade. Ao se disponibilizarem para desenhar, os participantes já demonstraram que podiam confiar em mim e nos seus pares, e que poderiam revelar seus segredos, pois seriam compreendidos e acolhidos. Durante a apresentação dos seus desenhos e de como se sentiam a respeito, alguns participantes começaram a relatar situações que tinham vivido, inclusive momentos da infância, e alguns se emocionaram e emocionaram os demais.

Essas reações espontâneas e reveladoras logo nas primeiras sessões, em que o objetivo era trabalhar através da persona, indicaram que, principalmente em alguns participantes, a ansiedade associada à retirada da máscara da persona (parte da persona que se encontra sob o controle consciente) era baixa, e que eles não temiam que alguns aspectos sombrios fossem percebidos pelos demais membros do grupo.

Essas reações também sinalizaram que o grupo estava vivenciando a primeira etapa da psicoterapia - A Confissão - em que conteúdos inconscientes reprimidos, deslocados para a sombra, podem ser liberados, essa liberação 
prenunciando o início da conscientização do conflito intrapsíquico. As emoções manifestadas durante os relatos evidenciaram que houve o que Jung (1971/1981) denomina de "confissão completa" que não abrange só a constatação intelectual, mas também a liberação dos afetos contidos.

No trabalho grupal, essa confissão assume características singulares, pois, como refere Hall (1989), o vaso alquímico grupal contém condições diferentes das existentes na análise individual. Esse autor assinala que, se de um lado, é mais fácil para o paciente confessar-se para seu analista do que frente ao grupo, em função do recipiente analítico individual ser suficientemente reassegurador e protetor para favorecer o confronto com a sombra, de outro lado, a própria condição de análise individual acarreta sentimentos, por parte do paciente, de que a aceitação incondicional do analista não assegura que as demais pessoas o aceitem também. Hall aponta que a discussão durante a psicoterapia grupal "liberta o indivíduo desse nível diferente de ansiedade - o temor de que ele seja rejeitado(a) pela sociedade [...] É mais comum que os membros do grupo aceitem por unanimidade a sombra de um indivíduo, mesmo que não gostem dela ou prefiram que ela seja modificada"( $p$. 144). Freitas (2005) também afirma que a relação humanizada desenvolvida durante a psicoterapia grupal faz com que as manifestações do arquétipo sombra sejam percebidas de forma construtiva.

É importante também lembrarmos que a confissão, no processo breve, está diretamente relacionada ao foco.

Freitas assinala que, além da relação intrapsíquica e do diálogo conscienteinconsciente, o trabalho grupal favorece as relações interpessoais e, com isso, o indivíduo tem oportunidade de se ver confrontado ou ser aceito pelos demais membros, mesmo tendo posições diferentes destes, desenvolvendo, dessa forma, o self relacional.

Ao longo das sessões, pude constatar que o acolhimento e o respeito foram freqüentes em todo o processo.

É importante registrar que alguns participantes tiveram mais dificuldade para passar por essa etapa de confissão, mas a iniciativa de outros membros e a forma como eu e o grupo, desde o início, acolhemos os desenhos e os comentários feitos, facilitou a vivência dessa fase do processo psicoterapêutico.

Nesse ponto já pude observar indícios de que o recurso expressivo escolhido - o desenho temático - e a estratégia de se trabalhar com ele tinham sido uma boa 
forma, tanto para mobilizar em cada participante o diálogo consciente-inconsciente através dos símbolos, como para ativar a integração do grupo, funcionando como um tipo de Imaginação Ativa, embora fosse uma atividade diretiva. Lembro aqui Furth (2004) quando este afirma que qualquer desenho possui um efeito catártico e essa catarse permite que o símbolo mova a energia psíquica interna e dê início ao processo de cura. As figuras desenhadas pelos participantes trouxeram muita informação sobre eles, e, por meio delas, pude acompanhar como estava se encaminhando a jornada da psique de cada um deles e do grupo.

Sant'Anna (2005) assinala que é possível, através do desenho, "objetivar a imagem e dialogar com ela, bem como despontencializá-la em momentos de intensa atividade psíquica" (p. 35). Esse autor recomenda um confronto direto com a imagem, afirmando que o trabalho com imagens constitui uma construção dialética para qual é necessário a existência de um ego razoavelmente estruturado. Como a imagem é a matéria-prima da psique, diz esse autor, não é aconselhável abordá-la de uma forma racional, redutiva e, portanto, desvitalizadora, ao contrário, é necessário uma abordagem compreensiva, não-interpretativa, que capte sua fluidez e dinamismo. E foi dessa forma que procurei abordar as imagens que emergiram nos desenhos: estimulava para que os participantes relatassem o que sentiam a respeito das próprias imagens e das dos demais.

Como exemplo, tem-se a reação de Fátima frente aos seus desenhos (ver anexos, p. 265).

FÁTIMA: Sou alegre, mas não gosto de me ver no espelho. Quando era jovem, queria ser mais velha, ter $70 / 80$ anos, ter cumprido meu caminho, uma espécie de fuga... tudo é um desafio para mim. Luto por um objetivo, ponho à prova. Por exemplo, aprender computador. Comprei um agora, leio as apostilas para saber como usar. Meus filhos... que tem as mais atualizadas. Hoje queria ser jovem. Tenho coração, gosto de ajudar, mas as pessoas não vêem isso em mim, me vêem normal. Não quero ir passear, fico quieta, não me vêem como eu sou. É diferente o que eu sou e o que vêem em mim. Queria ser mais dinâmica, mais corajosa. Sei que, se tiver que ir para um lugar novo em São Paulo, vou, mas é uma luta constante.

Este relato, bem como a maioria dos desenhos feitos pelo grupo, evidencia, como já foi mencionado, auto-estima baixa e sentimentos de menos-valia relacionados ao processo de envelhecimento, mas numa análise mais profunda pude identificar também que questões relacionadas à imagem corporal estão 
envolvidas, havendo indícios de uma imagem corporal comprometida na maioria dos participantes. Lembro aqui o conceito de imagem corporal, elaborado por Schilder (1980), como uma representação psicológica do corpo formada não só pelas vias sensoriais e cinestésicas, mas também pelos significados afetivos e cognitivos adquiridos durante a vida. Esse autor foi um dos pioneiros no estudo da imagem corporal e procurou enfatizar que a relação do indivíduo com o próprio corpo é condição básica para o contato com o corpo dos outros. Lowen (1979) acrescentou a esta visão a relação da imagem corporal com a identidade, apontando que, a partir do contato com o próprio corpo, a pessoa desenvolve a noção de quem ela é, da sua identidade. Diz ele que "Para saber quem ele é, o indivíduo precisa ter consciência daquilo que sente. [...] Sem esta consciência de sensação e atitudes corporais a pessoa torna-se dividida: um espírito desencarnado e um corpo sem alma" (p.16).

Vemos então que ao delimitarmos o foco - auto-estima - e observarmos os indícios de prejuízo na imagem corporal do grupo, estávamos direcionando nosso foco para um plano mais amplo que envolvia a identidade do idoso.

\section{Terceira Sessão: O Trabalho com Sonhos em Grupo}

$\mathrm{Na} 3^{a}$ sessão, alguns participantes relataram sonhos recentes, tidos após o início do nosso trabalho. Sabemos que na análise junguiana o sonho é uma manifestação do self, o arquétipo central da ordem, da totalidade, logo, a lembrança dos sonhos nesse momento evidenciou que um processo psíquico, individual e grupal, intenso estava em curso e que o grupo estava mobilizado terapeuticamente em direção a um desenvolvimento do self grupal. O material onírico relatado trouxe, de maneira geral, conteúdos provenientes mais da psique pessoal (os participantes estão com familiares em situações cotidianas, em ambiente familiar), o que é esperado nos momentos iniciais da análise, e, tal como aconteceu com os desenhos, os participantes se dispuseram espontaneamente a partilhar com o grupo seus sonhos e com isto demonstraram que se sentiam apoiados e aceitos por este.

Jung (1971/1984) refere que o sonho, como expressão direta do inconsciente, tem um significado prático fundamental durante a análise individual, mas na minha experiência tenho observado que o trabalho grupal tem outras características e exige outras modalidades de abordagem. Como afirma Gallbach 
(2003), "o trabalho com sonhos em grupos não é freqüente, já que os processos de análise junguiana, em sua grande maioria, são individuais e a apreciação dos sonhos ocorre nos moldes tradicionais, eminentemente interpretativos" (p.33).

Assim como Gallbach (2003), me propus nesta pesquisa a trabalhar com os sonhos dos participantes do grupo partindo do fato de que a imagem do sonho é o próprio sonho e engloba o seu significado, não procurando estimular associações com a vida do sonhador ou com suas lembranças.

Procurei estimular amplificações das imagens oníricas através de associações naturais, como refere Hall (1989), solicitando que o sonhador revelasse como se sentia frente ao seu sonho, como se sentira ao acordar e os comentários e sentimentos do grupo a respeito do sonho. Aqui fica evidente que o trabalho terapêutico é do próprio paciente: o estabelecimento do foco levando a um opus mais intenso e possibilitando que o processo seja mais curto. Utilizo a palavra opus exatamente como Jung definiu: uma mistura, uma transformação, um trabalho, um processo em andamento.

Como no trabalho analítico com os desenhos, procurei abordar as imagens oníricas de forma que o sonhador e o grupo se confrontassem com elas e fizessem uma ligação emocional, contemplando ao mesmo tempo o desenvolvimento de uma consciência reflexiva e o impacto emocional do sonho para o grupo.

Nessa abordagem imagética (Sant'Anna, 2005), as imagens são consideradas fenômenos psíquicos, manifestações da psique que contêm emoção e sentido e só podem ser vivenciadas e experimentadas emocionalmente.

Apresento, abaixo, o sonho relatado por Denise (ver anexos, p. 275) para exemplificar como utilizei essa abordagem.

DENISE: Também tive [um sonho]... Foi logo assim que a senhora [dirigindo-se a terapeuta] mandou marcar no caderninho... um foi com cachorro, mas não me lembrei.

T: Após nossa primeira sessão?

DENISE: É... foi com um grupo de pessoas numa casa que era minha. Não sei quem eram, mas associava com a minha família, porque são oito pessoas e minha família somos em oito: duas filhas, dois genros, três filhos e eu. A casa era um sobrado bem bonitinho, tinha plantas... gosto muito de plantas. Tinha outra casa atrás, eles não me deixavam entrar, não me deram a chave. Era estranho! Eles estavam dentro. Entrei com eles pela lateral e eles estavam dentro e eu não. Resolvi dizer que, se eles não me dessem a chave, eu ia jogar todas as flores lá de cima. Eu olhava as flores da sacada em cima e ninguém fazia nada. Então, subi não sei como. Estava cheio de flores "Costela de Adão", flores enormes, pequenas e eu lá de 